\title{
So Uncommon and so Singular, but Underexplored: An Updated Overview on Ethnobotanical Uses, Biological Properties and Phytoconstituents of Sardinian Endemic Plants
}

\author{
Cinzia Sanna ${ }^{1,2, *}$, Andrea Maxia ${ }^{1,2}$, Giuseppe Fenu ${ }^{1}\left(\mathbb{C}\right.$ and Maria Cecilia Loi ${ }^{1}$ \\ 1 Department of Life and Environmental Sciences, University of Cagliari, Via Sant'Ignazio da Laconi 13, \\ 09123 Cagliari, Italy; a.maxia@unica.it (A.M.); gfenu@unica.it (G.F.); loimc@unica.it (M.C.L.) \\ 2 Co.S.Me.Se-Consorzio per lo Studio dei Metaboliti Secondari, Via Sant'Ignazio da Laconi 13, \\ 09123 Cagliari, Italy \\ * Correspondence: cinziasanna@unica.it
}

Received: 13 July 2020; Accepted: 27 July 2020; Published: 29 July 2020

\begin{abstract}
The last decades have recorded an increase of plant-based drug discovery processes. Indeed, natural products possess a superior chemical diversity as compared to synthetic ones, leading to a renewal in searching for new therapeutic agents from the plant kingdom. In particular, since the structural variety of natural compounds reflects the biodiversity of their source organisms, regions of the world with high biodiversity and endemism deserve particular interest. In this context, Sardinia Island (Italy), with 290 endemic taxa (12\% of the total flora), is expected to provide unique and structurally diverse phytochemicals for drug development. Several research groups built up a large program dedicated to the analysis of Sardinian endemic species, highlighting their peculiar features, both in respect of phytochemical and biological profiles. On this basis, the aim of this review is to provide an up-to-date and comprehensive overview on ethnobotanical uses, biological properties and phytoconstituents of Sardinian endemic plants in order to support their beneficial potential and to provide input for future investigations. We documented 152 articles published from 1965 to June 2020 in which a broad range of biological activities and the identification of previously undescribed compounds have been reported, supporting their great value as sources of therapeutic agents.
\end{abstract}

Keywords: Sardinia; endemic species; biodiversity; ethnomedicine; biological activities; secondary metabolites

\section{Introduction}

Plants have been a valuable source of therapeutic agents for thousands of years, and their constituents have provided a substantial number of the natural product-derived drugs currently used in Western medicine [1,2]. Indeed, at least one quarter of the commonly used drugs are directly obtained or derived from plants [2]. This percentage considerably increases in particular areas, such as those of anticancer and antiviral drugs [2].

The plant-based drug discovery process reached its peak in the 1970-1980 decade, after which, in spite of its high value as a source of novel medicines, it has gradually decreased, because of the known perceived disadvantages and difficulties (e.g., availability of plant material, stricter regulations to safeguard and conserve plant diversity, seasonal and/or environmental variations of plant metabolites, high structural complexity of plant compounds, etc). Owing to these problems, and to the significant time-consuming and expensive compound isolation, many pharmaceutical companies have significantly scaled back or abandoned their natural product programs in favor of 
automated high throughput screenings (HTS) of synthetic compounds libraries [3]. Therefore, natural extracts were replaced with synthetic molecules. However, a small number of newly introduced drugs from an origin in HTS of combinatorial chemistry libraries have reached the market in the last years $[3,4]$.

These disappointments, and the awaraness that natural products possess a superior chemical diversity as compared to synthetic ones, have led to a renaissance of the interest in searching for new plant-based drugs [5,6].

It is currently estimated that only approximately $6 \%$ of the plant kingdom has been screened for biologic activity, and only 15\% for their phytochemical profiles [7], thus the vast majority of plants' diversity is yet to be exploited. Since the chemical diversity of plant secondary metabolites can reflect the biodiversity of their source organisms, regions with high rates of endemisms could be particularly interesting in searching for new bioactive compounds, as is widely documented [8-12].

In this context, the Mediterranean Basin deserves particular interest, since it is widely recognized as one of the hot spots of terrestrial biodiversity [13-15]. This area, which corresponds to $2 \%$ of the world's surface, is characterized by a high rate of endemism, with approximately $60 \%$ of all native taxa being Mediterranean endemics, and half of which correspond to endemic sensu stricto $[13,16,17]$. Nevertheless, this endemic plant richness is irregularly distributed $[13,16,18]$; in particular, endemic plant diversity occurs on the large Mediterranean islands and archipelagos that represent the principal centers of diversity having an endemism rate of more than $40 \%$, particularly due to the restricted range of most of their flora [16,19].

Within Mediterranean islands, Sardinia (Italy), with its total area of approximately $24,000 \mathrm{~km}^{2}$, is the second largest island after Sicily $[13,18]$. Sardinian flora consists of 2441 taxa of native vascular plants [20]; out of them, 290 are endemic (183 taxa exclusive to Sardinia, 90 Sardo-Corsican and 17 also present in the Tuscan Archipelago) [18]. This endemic richness is attributable to the long geological history of the island, its prolonged geographical isolation and the high geomorphological diversity, especially on its mountain massifs, which have contributed to developing a wide range of habitats $[13,18,21]$. It is expected that this relative high rate of endemism provides a plethora of unique and structurally diverse phytochemicals for drug development. Consequently, in the last decades, several research groups have built up a large program dedicated to the analysis of Sardinian endemic species, highlighting their peculiar features, both in respect of the phytochemical profiles and biological potential.

On this basis, the aim of this review was to provide for the first time an up-to-date and comprehensive overview of ethnobotanical uses, chemical constituents and pharmacological properties of Sardinian endemic plants, in order to facilitate further investigations into the complete chemical profile of the secondary metabolites, as well as their pharmacological activities and molecular mechanisms.

\section{Methodology}

An in-depth research on the available literature was conducted on ethnobotanical uses, phytoconstituents and biological activities of Sardinian endemic plants. Information was mainly collected from international peer-reviewed papers found via online scientific databases, namely Medline (PubMed), Scopus, Web of Science, Researchgate and Google Scholar. As keywords, the Linnean binomial of each taxon were firstly used; in addition, a second query was also performed including their associated synonyms. Out of the articles found, only those regarding traditional uses, biological properties and phytochemical data were considered. The list of endemic species was obtained from Fenu et al. [18] for those plants growing in Sardinia, Corsica and Tuscan Archipelago. Moreover, other endemic plants, distributed in a wide area, were considered, according to the most relevant articles on Sardinian floras recently published [13,18,22,23].

In addition to the online-published papers, data on the usage of Sardinian endemic plants in traditional medicine were also sourced from paper articles and books. All articles have been published from 1965 to June 2020. 


\section{Results and Discussion}

Our literature search led to one-hundred and fifty-two articles, covering fifty-one Sardinian endemic species (around 17\% of total endemic flora) belonging to nineteen families and thirty-four genera. Out of articles on chemical analysis and biological evaluation, those which referred to samples collected in Corsica have also been found and then considered. As shown in Figure 1, the number of articles considerably increased in the last two decades, evidencing a great interest of the scientific community in searching for new compounds from unstudied or underexplored plants. In fact, biodiversity-rich regions, such as Sardinia, provide unique chemical scaffolds that could be used as templates for medicinal chemistry.

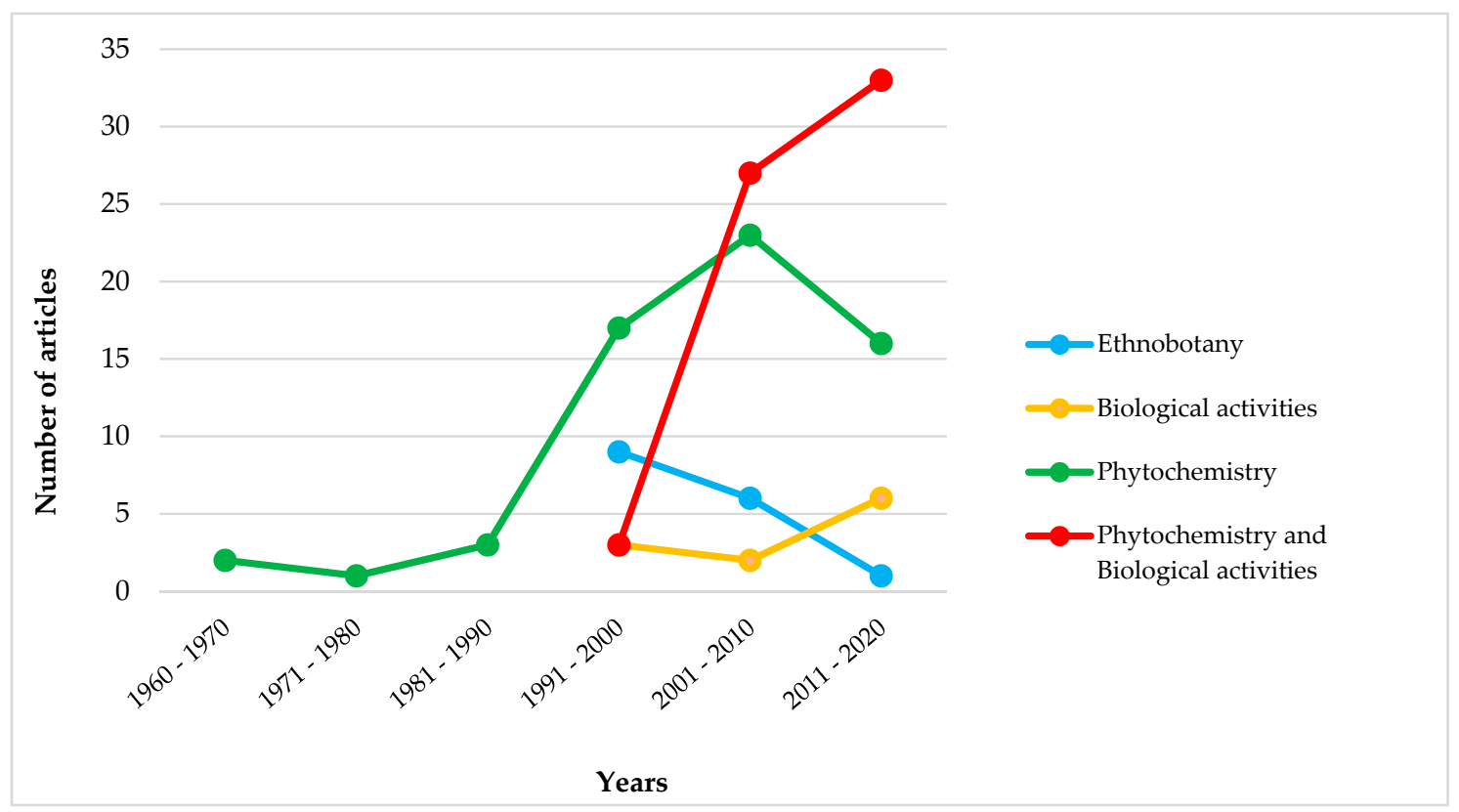

Figure 1. Number of articles on ethnobotanical uses, phytochemical features and/or pharmacological properties of Sardinian endemic species published from 1965 to $2020(n=152)$.

The first articles concerned the isolation and structural elucidation of secondary metabolites (Figure 1). Interestingly, they were published about thirty years before the first reports on uses of Sardinian endemic species for medicinal purposes. Indeed, ethnobotanical surveys in which Sardinian endemic plants were used by local inhabitants have been published since 1991. This suggests that ethnobotanical information did not play a key role in the plant selection for chemical studies. The number of articles regarding only chemical features has progressively decreased since 2001, and simultaneously, those in which the evaluation of biological activity is coupled with the identification of bioactive compounds increased. In fact, the interest for the therapeutic potential of Sardinian endemic plants started in the 1990s and has progressively intensified until today. Instead, the number of articles describing biological properties of crude extracts is considerably lower. Indeed, the complex mixtures produced from plants are perceived to be incompatible with high throughput screenings, because they often contain some components, such as tannins, which can produce false-positive results in both enzymatic and cellular assays [3].

The list of endemic plants that came to light in our review is shown in Table 1, together with their distribution range; specifically, twenty taxa are exclusive to the island, sixteen are present in Sardinia and Corsica, and nine are endemic of Sardinia, Corsica and Tuscan Archipelago. The remaining six taxa are recorded also in Sicily, Balearic Islands, other minor Mediterranean islands and islets, and along the Mediterranean coasts of the Italian Peninsula. Fabaceae, Asteraceae and Lamiaceae are the highest studied families. 
Table 1. List of Sardinian endemic species for which ethnobotanical, phytochemical and/or pharmacological data have been published (1965-2020). For each taxon, the distribution range was reported by using the following acronyms: SA (Sardinia); CO (Corsica); AT (Tuscan Archipelago); BL (Balearic Islands); HI (Hyères Island); LI (Liguria); TO (Tuscany); SI (Sicily); TN (Tunisia).

\begin{tabular}{|c|c|c|}
\hline Family & Taxon & Distribution Range \\
\hline Amaryllidaceae & Pancratium illyricum $\mathrm{L}$. & SA-CO-AT \\
\hline \multirow{2}{*}{ Apiaceae } & Ferula arrigonii Bocchieri & SA-CO \\
\hline & Seseli praecox (Gamisans) Gamisans & $\mathrm{SA}-\mathrm{CO}$ \\
\hline Apocynaceae & Vinca difformis Pourr. subsp. sardoa Stearn & SA \\
\hline Araceae & Arum pictum L.f. subsp. pictum & SA-CO \\
\hline Aristolochiaceae & Aristolochia tyrrhena E.Nardi \& Arrigoni & SA-CO-AT \\
\hline \multirow[t]{9}{*}{ Asteraceae } & Artemisia caerulescens L. subsp. densiflora (Viv.) Kerguélen \& Lambinon & SA-CO \\
\hline & Centaurea horrida Badarò & SA \\
\hline & $\begin{array}{l}\text { Helichrysum italicum (Roth) G.Don subsp. tyrrhenicum (Bacch., Brullo \& } \\
\text { Giusso) Herrando, J.M.Blanco, L.Sáez Galbany }\end{array}$ & $\mathrm{SA}-\mathrm{CO}$ \\
\hline & Helichrysum saxatile Moris subsp. saxatile & SA \\
\hline & Plagius flosculosus (L.) Alavi \& Heywood & SA-CO-AT \\
\hline & Ptilostemon casabonae (L.) Greuter & SA-CO-HI \\
\hline & Santolina corsica Jord. \& Fourr. & SA-CO \\
\hline & Santolina insularis (Gennari ex Fiori) Arrigoni & SA \\
\hline & Tanacetum audibertii (Req.) DC. & $\mathrm{SA}-\mathrm{CO}$ \\
\hline \multirow[t]{2}{*}{ Boraginaceae } & Borago morisiana Bigazzi \& Ricceri & SA \\
\hline & Borago pygmaea (DC.) Chater \& Greuter & SA-CO-AT \\
\hline \multirow[t]{3}{*}{ Euphorbiaceae } & Euphorbia hyberna L. subsp. insularis (Boiss.) Briq. & SA-CO-LI-TO \\
\hline & Euphorbia pithyusa L. subsp. cupanii (Guss. ex Bertol.) Radcl.-Sm. & SA-CO-SI \\
\hline & Euphorbia semiperfoliata Viv. & $\mathrm{SA}-\mathrm{CO}$ \\
\hline \multirow[t]{10}{*}{ Fabaceae } & Astragalus verrucosus Moris & SA \\
\hline & Bituminaria morisiana (Pignatti \& Metlesics) Greuter & SA-TN \\
\hline & Genista arbusensis Vals. & SA \\
\hline & Genista bocchierii Bacch., Brullo \& Feoli Chiapella & SA \\
\hline & Genista cadasonensis Vals. & SA \\
\hline & Genista corsica (Loisel.) DC. & SA-CO \\
\hline & Genista ephedroides DC. & $\mathrm{SA}-\mathrm{CO}$ \\
\hline & Genista morisii Colla & SA \\
\hline & Genista pichisermolliana Vals. & SA \\
\hline & Genista sulcitana Vals. & SA \\
\hline \multirow[t]{2}{*}{ Hypericaceae } & Hypericum hircinum L. subsp. hircinum & SA-CO-AT \\
\hline & Hypericum scruglii Bacch., Brullo \& Salmeri & SA \\
\hline \multirow[t]{6}{*}{ Lamiaceae } & Glechoma sardoa (Bég.) Bég. & SA \\
\hline & Mentha requienii Benth. subsp. requienii & SA-CO \\
\hline & Salvia desoleana Atzei \& V.Picci & SA \\
\hline & Stachys corsica Pers. & SA-CO \\
\hline & Stachys glutinosa L. & SA-CO-AT \\
\hline & Thymus herba-barona Loisel. subsp. herba-barona & SA-CO \\
\hline Orobanchaceae & Euphrasia nana (Rouy) Prain & $\mathrm{SA}-\mathrm{CO}$ \\
\hline \multirow[t]{2}{*}{ Plantaginaceae } & Cymbalaria muelleri (Moris) A.Chev. & SA \\
\hline & Linaria flava (Poir.) Desf. subsp. sardoa (Sommier) A.Terracc. & $\mathrm{SA}-\mathrm{CO}$ \\
\hline \multirow[t]{2}{*}{ Plumbaginaceae } & Limonium contortirameum (Mabille) Erben & $\mathrm{SA}-\mathrm{CO}$ \\
\hline & Limonium morisianum Arrigoni & SA \\
\hline Polygalaceae & Polygala sardoa Chodat & SA \\
\hline Ranunculaceae & Staphisagria requienii (DC.) Spach subsp. picta (Willd.) Peruzzi & SA-CO-BL-HI \\
\hline \multirow[t]{3}{*}{ Rubiaceae } & Galium corsicum Spreng. & $\mathrm{SA}-\mathrm{CO}$ \\
\hline & Galium glaucophyllum Em.Schmid & SA \\
\hline & Galium schmidii Arrigoni & SA \\
\hline \multirow[t]{2}{*}{ Scrophulariaceae } & Scrophularia trifoliata $\mathrm{L}$. & SA-CO-AT \\
\hline & Verbascum conocarpum Moris subsp. conocarpum & SA-CO-AT \\
\hline Urticaceae & Urtica atrovirens Req. ex Loisel. & SA-CO-AT \\
\hline
\end{tabular}

\subsection{Ethnobotanical Uses}

Sixteen articles on traditional uses of Sardinian endemic species have been found. Ethnobotanical uses, along with information on the part(s) of plant used, type of preparation and places where they have been used, and their respective references, are reported in Table 2.

Despite the rich and ancient Sardinian ethnobotanical tradition [24,25], only twenty-one endemic plants have been used in traditional medicine, probably because of their extreme rareness. In fact, largely used medicinal plants are usually common species, since they are abundant and available [26]. Dermatological problems, respiratory ailments and gastrointestinal conditions are the most frequent categories of use. Leaves, whole plant, underground organs (roots, rhizomes, tubers or bulbs), 
stems and flowers are the parts of plant more frequently used. With regard to the preparations, infusion and decoction stand out as the most used, followed by cataplasm or direct application. The latter are mostly prepared to treat skin diseases and as an anti-rheumatic. Peculiar references concern the use of Scrophularia trifoliata for the Basedow's disease, an autoimmune disorder [27], and Vinca difformis subsp. sardoa as an antitubercular [28]. With the exceptions of Cymbalaria muelleri [29,30], Glechoma sardoa [29,30], Ptilostemon casabonae [30] and Verbascum conocarpum subsp. conocarpum [30], which have been used in just one territory, the others plants were largely employed by Sardinian inhabitants.

It is noteworthy that, out of the twenty-one endemic species used in traditional medicine, sixteen have been subjected to phytochemical and/or pharmacological investigation, often exhibiting interesting properties, even though they are different from their uses in Sardinian ethnomedicine (see the paragraph 3.2 Pharmacological activities). Indeed, to date, limited scientific studies have aimed at supporting their traditional uses. As shown in Figure 2, our literature search pointed out that the selection of endemic plants for extract screening has probably been achieved by different approaches, with no regard for the ethnobotanical information, according to what has been observed in Figure 1.

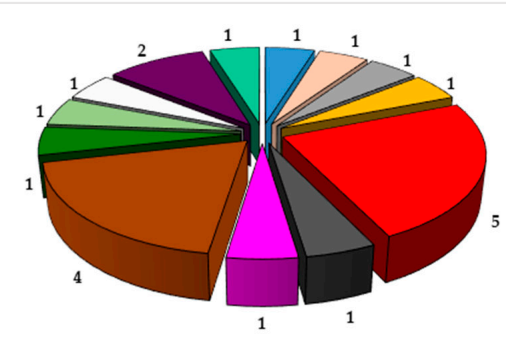

(a)

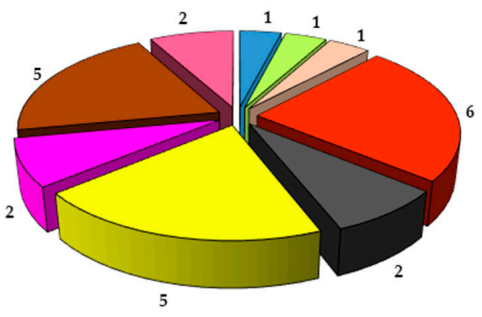

(b)

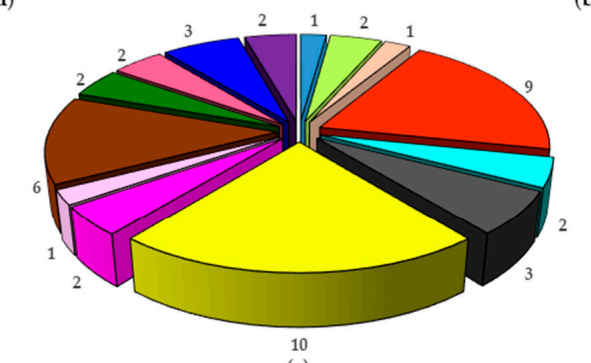

(c)
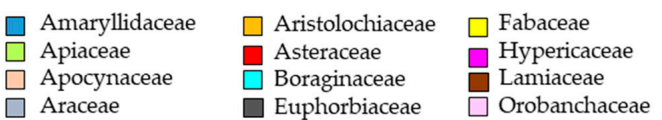

$\square$ Plantaginaceae Plumbaginace Polygalaceae

Euphor

Orobanchace

$\square$ Polygalaceae

Figure 2. Overview of Sardinian endemic species, grouped by families, for which ethnobotanical (a), pharmacological (b) and phytochemical (c) data have been published (1965-2020).

Indeed, even though the ethnomedicine has guided the field of bioscreening for a long time, often leading to the discovery of several plant-derived drugs [31], in the discovery of new drug leads from medicinal plants, chemotaxonomic and biodiversity-driven approaches can also be adopted [3]. The former allows for predicting that a plant is taxonomically related to others, which produce certain classes of natural products and may contain similar metabolites. Conversely, the biodiversity-driven approach, namely random screening, consists of selecting plants based on their availability [3].

Five endemic taxa, namely Aristolochia thyrrena (Aristolochiacee), Arum pictum subsp. pictum (Araceae), Polygala sardoa (Polygalaceae), Staphisagria requienii subsp. picta (Ranunculaceae) and Urtica atrovirens (Urticaceae) have not been subjected to further investigation, despite their acceptance and documented uses among the local inhabitants. Indeed, to the best of our knowledge, they lack chemical in-depth analysis and phytotherapeutic evidences. Conversely, species belonging to Fabaceae, Apiaceae, Boraginaceae, Orobanchaceae, Plumbaginaceae and Rubiaceae families have been selected for biological and phytochemical evaluation, even though they are not used in Sardinian ethnomedicine (Table 2). 
Table 2. Ethnobotanical uses of Sardinian endemic species.

\begin{tabular}{|c|c|c|c|c|c|}
\hline Taxon & Ethnobotanical Uses & Part(s) of the Plant Used & Preparation & Territories & References \\
\hline Aristolochia thyrrena & Emmenagogue, vulnerary & WP & Infusion & Barbagia Seui, Seulo, Sadali & {$[30,32,33]$} \\
\hline \multirow[t]{5}{*}{ Arum pictum subsp. pictum } & Vulnerary, burns and scalds & $\mathrm{L}, \mathrm{T}$ & Cataplasm & $\begin{array}{l}\text { Villagrande Strisaili, Barbagia Seui, Urzulei, } \\
\text { Barbagia Seulo }\end{array}$ & [30,32-35] \\
\hline & Diuretic, nervous sedative & $\mathrm{L}$ & Decoction & Urzulei & {$[30,34]$} \\
\hline & Haemostatic & $\mathrm{L}$ & Direct application & Tempio Pausania & {$[30,36]$} \\
\hline & Anti-rheumatic & $\mathrm{F}$ & Cataplasm & Urzulei, Barbagia Seui, Barbagia Seulo & {$[30,32,34]$} \\
\hline & Skin lightening & $\mathrm{T}$ & Latex & Villamassargia & {$[30]$} \\
\hline Cymbalaria muelleri & $\begin{array}{l}\text { Burns, chilblains, skin inflammation, } \\
\text { hemorrhoids }\end{array}$ & $\mathrm{AP}$ & Cataplasm & Laconi & {$[29,30]$} \\
\hline \multirow{3}{*}{$\begin{array}{l}\text { Euphorbia pithyusa subsp. } \\
\text { cupanii }\end{array}$} & Removal of warts & LX & Direct application & Barbagia Seui, Sadali, Seulo & {$[30,32,33]$} \\
\hline & Antiasthmatic & FP & Decoction & Barbagia Seui, Sadali, Seulo & {$[30,32]$} \\
\hline & Analgesic & LX & Direct application & Bolotana & {$[30]$} \\
\hline \multirow{2}{*}{ Glechoma sardoa } & $\begin{array}{l}\text { Respiratory diseases, chronic catarrh, } \\
\text { bronchitis, antiasthmatic, wound healing }\end{array}$ & F and $S$ & Infusion with milk and honey & Laconi & {$[29,30]$} \\
\hline & $\begin{array}{l}\text { Vulnerary, resolvent in scalds, antinevralgic, } \\
\text { antirheumatic }\end{array}$ & F and $S$ & $\begin{array}{l}\text { Infusion, infusion with milk and honey } \\
\text { (direct application) }\end{array}$ & Laconi & {$[29,30]$} \\
\hline \multirow{4}{*}{$\begin{array}{l}\text { Helichrysum italicum subsp. } \\
\text { tyrrhenicum }\end{array}$} & Anti-allergic & WP & Infusion & Urzulei & [34] \\
\hline & $\begin{array}{l}\text { Skin diseases (alopecia), diaphoretic, burns, } \\
\text { vulnerary }\end{array}$ & $\mathrm{WP}, \mathrm{FH}, \mathrm{S}$ & Decoction, infusion, cataplasm & Fluminimaggiore, Gesturi, Tempio Pausania & {$[27,36,37]$} \\
\hline & $\begin{array}{l}\text { Bronchitis, laryngitis, tracheitis, cough } \\
\text { sedative, expectorant }\end{array}$ & $\mathrm{L}, \mathrm{FH}$ & Infusion & $\begin{array}{l}\text { Barbagia Seui, Laconi, Escolca, Tempio } \\
\text { Pausania }\end{array}$ & {$[29,32,36,38]$} \\
\hline & Antineuralgic, antirheumatic & FH & Infusion & Barbagia Seui, Laconi, Tempio Pausania & {$[29,32,36]$} \\
\hline \multirow{3}{*}{$\begin{array}{l}\text { Hypericum hircinum subsp. } \\
\text { hircinum }\end{array}$} & Burns and wound healing & $\mathrm{F}$ & Macerate in olive oil & Laconi & {$[29,30]$} \\
\hline & Antirheumatic, sciatica, dislocation & $\mathrm{F}$ & Macerate in olive oil and wine & Laconi & {$[29,30]$} \\
\hline & Balsamic, antiasthmatic & WP & Infusion & Laconi & {$[29,30]$} \\
\hline Pancratium illyricum & $\begin{array}{l}\text { Depurative, diuretic, emetic, corn removal, } \\
\text { antiseptic }\end{array}$ & B & Powder, cataplasm & Tonara, Iglesiente & [30] \\
\hline Polygala sardoa & Fluidifyng & $\mathrm{R}$ & Decoction & Laconi & {$[29,30]$} \\
\hline Ptilostemon casabonae & Antispasmodic & $\mathrm{AP}$ & Ingestion & Urzulei & [30] \\
\hline \multirow{3}{*}{ Salvia desoleana } & Antipyretic, anti-inflammatory & $\mathrm{S}$ and $\mathrm{L}$ & Decoction & Loceri & [30] \\
\hline & Vulnerary & $\mathrm{L}$ & Cataplasm & Loceri & [30] \\
\hline & External anti-inflammatory & $\mathrm{L}$ & Heated in oil & Villanovaforru & [30] \\
\hline Santolina corsica & $\begin{array}{l}\text { Anthelmintic, tonic, emmenagogue, } \\
\text { insect repellent }\end{array}$ & $\mathrm{AP}$ & Not available information & Lodè, Lula & [30] \\
\hline
\end{tabular}


Table 2. Cont

\begin{tabular}{|c|c|c|c|c|c|}
\hline Taxon & Ethnobotanical Uses & Part(s) of the Plant Used & Preparation & Territories & References \\
\hline \multirow{3}{*}{ Santolina insularis } & Insect repellent (pediculus) & WP, S, L & Fumigation & Arzana, Villagrande Strisaili & {$[35,39]$} \\
\hline & Anthelmintic & FH, L & Infusion & Marganai, Laconi & {$[29,40]$} \\
\hline & Febrifuge, sedative, antitussive & $\mathrm{L}$ & Decoction & Villagrande Strisaili & [35] \\
\hline \multirow{7}{*}{ Scrophularia trifoliata } & $\begin{array}{l}\text { Skin diseases, vulnerary, anti-edema, } \\
\text { antirheumatic }\end{array}$ & $\mathrm{L}, \mathrm{FH}, \mathrm{RH}$ & $\begin{array}{l}\text { Infusion, cataplasm of fresh leaves with olive } \\
\text { oil, cream }\end{array}$ & $\begin{array}{l}\text { Ussassai, Urzulei, Villagrande Strisaili, } \\
\text { Escolca }\end{array}$ & {$[28,33-35,38]$} \\
\hline & Diuretic & $\mathrm{L}$ & Decoction & Escolca & [38] \\
\hline & Emollient & $\mathrm{R}$ & Direct application & Barbagia Seui, Sadali, Seulo & {$[30,32,33]$} \\
\hline & Anthelmintic & $\mathrm{R}$ & Powder with honey & Barbagia Seui, Sadali, Seulo & {$[30,32]$} \\
\hline & $\begin{array}{l}\text { Purgative, emetic, Basedow's disease and } \\
\text { related heart disorders }\end{array}$ & $\mathrm{L}$ & Infusion & Gesturi & {$[27]$} \\
\hline & Antirheumatic, vurnerary & $\mathrm{L}$ & Cataplasm & Urzulei & [30] \\
\hline & $\begin{array}{c}\text { Antipyretic, anti-inflammatory, tonsillitis, } \\
\text { sore throat }\end{array}$ & $\mathrm{L}$ & Cataplasm & Aggius & [30] \\
\hline \multirow{4}{*}{ Stachys glutinosa } & Hepatoprotective, cholagogue, diuretic & $\mathrm{L}$ & Decoction & Gesturi & [27] \\
\hline & Common cold & $\mathrm{L}$ & Decoction & Villagrande Strisaili & [35] \\
\hline & Antiseptic, antispasmodic & WP & Infusion & Arzana & {$[30,33,39]$} \\
\hline & Sedative & WP & Infusion & Bolotana & {$[30]$} \\
\hline Staphisagria requienii subsp. picta & Antiparasitic (lice, nits, mites), vulnerary & L, SE & Ointment, powder & Barbagia Seui, Bolotana & {$[30,32]$} \\
\hline Tanacetum audibertii & $\begin{array}{l}\text { Digestive, anthelmintic, anti-arthritic, } \\
\text { emmenagogue }\end{array}$ & $\mathrm{AP}$ & Decoction & Not available information & [30] \\
\hline \multirow{8}{*}{$\begin{array}{l}\text { Thymus herba-barona subsp. } \\
\text { herba barona }\end{array}$} & Anthelmintic, digestive, to treat gastralgia & WP, S, L, R & Decoction, infusion & Arzana, Urzulei, Laconi & {$[29,34,39]$} \\
\hline & Antirheumatic & WP & Cataplasm & Urzulei & [34] \\
\hline & $\begin{array}{c}\text { Cough sedative, whooping cough, } \\
\text { expectorant }\end{array}$ & $\mathrm{L}, \mathrm{F}$ & Infusion with milk, decoction & Arzana, Ussassai, Laconi & {$[28,29,39]$} \\
\hline & Antipyretic & WP & $\begin{array}{l}\text { Decoction with malva and lemon, soaked in } \\
\text { "grappa" }\end{array}$ & Arzana, Urzulei & {$[34,39]$} \\
\hline & $\begin{array}{c}\text { Sore throat, common cold, cough, bronchitis, } \\
\text { asthma, tonic, antianaemic, intestinal } \\
\text { antispasmodic, diuretic }\end{array}$ & $\mathrm{L}, \mathrm{S}$ & $\begin{array}{l}\text { Decoction, inhalation of infusion with malva, } \\
\text { rosemary and sage }\end{array}$ & $\begin{array}{l}\text { Arzana, Villagrande Strisaili, Laconi, Urzulei, } \\
\text { Perdasdefogu }\end{array}$ & {$[29,34,35,39,41]$} \\
\hline & Cold & $\mathrm{R}$ and $\mathrm{F}$ & Inhalation of decoction & Arzana & [39] \\
\hline & Antiseptic, tonic, disinfectant, mouthwash & $\mathrm{L}, \mathrm{L}$ and $\mathrm{R}$ & Infusion, decoction & Perdasdefogu, Arzana & {$[33,39,41]$} \\
\hline & Urticaria, foot perspiration & WP & Powder & Perdasdefogu & {$[33,41]$} \\
\hline
\end{tabular}


Table 2. Cont

\begin{tabular}{|c|c|c|c|c|c|}
\hline Taxon & Ethnobotanical Uses & Part(s) of the Plant Used & Preparation & Territories & References \\
\hline & Lenitive & $\mathrm{L}$ & Cataplasm & Ussassai & {$[28]$} \\
\hline & Toothache & $\mathrm{R}$ & Chewing & Arzana & [39] \\
\hline \multirow[t]{2}{*}{ Urtica atrovirens } & $\begin{array}{l}\text { Baldness, rashes, vulnerary, hemostatic, } \\
\text { antirheumatic, emmenagogue, gastralgia }\end{array}$ & $\mathrm{L}, \mathrm{WP}$ & Infusion & Lotzorai, Marganai, Domusnovas & {$[30,38,40]$} \\
\hline & Diuretic & WP, L & Infusion, syrup & Barbagia Seui, Marganai, Seulo, Sadali & {$[30,32,40]$} \\
\hline $\begin{array}{l}\text { Verbascum conocarpum subsp. } \\
\text { conocarpum }\end{array}$ & Anti-inflammatory, anti-catarrhal & $\mathrm{L}$ & Decoction, fumigation & La Maddalena Archipelago & [30] \\
\hline \multirow{5}{*}{ Vinca difformis subsp. sardoa } & Anti-rheumatic & $\mathrm{L}$ & Application of heated leaves & Ussassai & [42] \\
\hline & Sedates nausea & $\mathrm{L}$ & Infusion & Escolca & [38] \\
\hline & $\begin{array}{c}\text { Anti-emetic, eupeptic, anti-inflammatory, } \\
\text { anti-hemorragic, galactofuge, astringent, } \\
\text { hypotensive, hypoglycaemic }\end{array}$ & $\mathrm{L}$ & Decoction, infusion & Laconi, Perdasdefogu, Escolca, Monteleone & {$[29,38,41,42]$} \\
\hline & Antitubercular & $\mathrm{L}$ & Infusion, maceration & Monteleone & [42] \\
\hline & Bronchitis & $\mathrm{L}$ & Poultice & Lodine & [43] \\
\hline
\end{tabular}

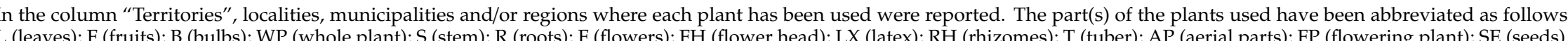




\subsection{Pharmacological Activities}

Overall, seventy-four scientific articles, in which essential oils, crude extracts and/or pure compounds isolated from twenty-five Sardinian endemic species have been evaluated for their therapeutic potential, were found in the literature (Supplementary Table S1). Several categories of biological activities have been identified and the most represented were those of antimicrobials, anticancers, antioxidants and antivirals (Figure 3). All these categories are discussed, item by item, below.

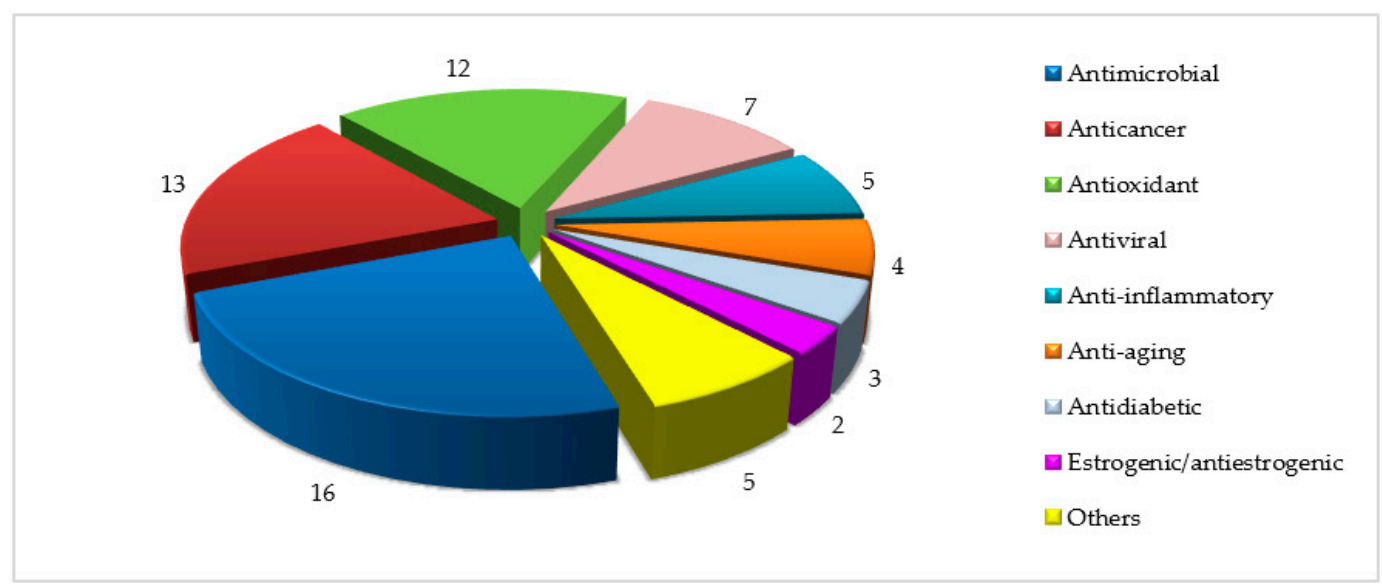

Figure 3. Number of Sardinian endemic species grouped by their documented biological activities.

\subsubsection{Antimicrobial Activity}

Since their discovery, antibacterial drugs have become an essential part of the present healthcare scenery, even though their incorrect use or abuse cause the growth and spread of microorganisms resistant to their action, with consequent loss of efficacy of the therapies. Indeed, antimicrobial resistance (AMR) is nowadays recognized as a global public health problem [44]. Consequently, in this scenario, there is an urgent need of new effective antifungals and antibacterials without undesirable side effects, and plants could give a very important contribution [45].

Our survey led to sixteen Sardinian endemic plants with antimicrobial properties.

Essential oils of Artemisia caerulescens subsp. densiflora and Mentha requienii subsp. requienii showed antifungal properties against environmental isolates of yeasts and molds strains (Rhodotorula spp., Candida spp., Aspergillus spp., Alternaria spp. and Fusarium spp.), suggesting their possible use as alternatives to the common disinfectants and also as post-harvest control of cereals [46,47]. N-hexan extract obtained from Astragalus verrucosus exhibited antibacterial activity against Gram+ bacteria (Staphylococcus aureus), while polar extracts, especially the butanol one, showed antifungal activity against Aspergillus niger and Botrytis cinerea [48]. The activity of the polar extract could be attributable to the flavonoid compounds [49]. In addition, the new saponin isolated from this plant, namely astraverrucin II, showed a significant antifungal effect, maybe due to the presence of an acetyl group. Indeed, the other astraverrucins lacking of this group were not active [48].

Ethyl acetate extract of whole plant and the acetonitrile extract of latex of Euphorbia semiperfoliata were able to inhibit the multidrug transporter CaMdr1p of Candida albicans. In particular, the antibacterial activity of a diterpenoid ester seems to be related to the presence of an isobutyrate group at C-8, instead of an acetoxy or hydroxyl group [50]. The essential oil of Glechoma sardoa, studied by the agar dilution method, was effective against Gram+ bacteria, such as S. aureus and S. epidermidis, but no activity was observed on Gram-bacterial strains [51]. Helichrysum italicum subsp. thyrrenicum showed a strong antimicrobial activity: both the essential oil and methanol extract exhibited antifungal properties against Candida ssp. and Pythyum ultimum, the latter is a phytopathogen [52-54]. Interestingly, the anticandidal activity of the oil is enhanced by sub-inhibitory concentrations of chitosan, suggesting its use in innovative formulations, as a therapeutic alternative in the treatment of Candida opportunistic 
infections [53]. It is worth noting that it is well-known that the antimicrobial activity of Helichrysum ssp. is generally attributed to nerol esters [55,56]; however, in Sardinian samples, the antibacterial activity was observed in the chemotype rich in rosifoliol but missing nerol and its esters [52]. The methanol extract is also active against the dermatophyte Trichophyton mentagrophytes var. mentagrophytes and against Gram + bacteria, such as Micrococcus luteus [54]. Interestingly, the heterodimeric phloroglucinol $\alpha$-pyrone arzanol exhibited a significant antibacterial activity against multidrug-resistant $S$. aureus isolates [57]. In particular, it was active on bacterial strains, which overexpress the NorA pump [57], a transporter able to efflux a wide range of antibiotics [58]. The oil macerate of aerial parts was found to be active against Candida spp. clinical isolates [59]. All these results validated the topical use of Helichrysum extracts to prevent wound infections and treat skin diseases in traditional medicine [37].

Recently, a remarkable activity of Limonium morisianum towards multidrug-resistant S. epidermidis clinical isolates has been described as well as the correlation among total phenolic content and increasing antibacterial activity [60].

The antibacterial activity of ungeremine, an alkaloid extracted from bulbs of Pancratium illyricum able to impair both human and bacterial (Escherichia coli) topoisomerases, was recently described [61]. These enzymes are two new interesting targets in antimicrobial chemotherapy. Moreover, the alkaloid extract of bulbs, and especially lycorine, was identified as the major active component with a potent inhibitory effect on C. albicans clinical isolates [62]. On the contrary, lycorine did not exert antibacterial activity, probably because of the ability of some bacteria, such as $S$. aureus, to transform it in its inactive metabolite 2-O-demethylungiminorine, instead of the active one, ungeremine [63].

Both essential oil and supercritical fluid extract from Plagius flosculosus exhibited antifungal properties against C. albicans and Mycobacterium smegmatis [64]: since the antimicrobial concentrations were generally higher than cytotoxic doses, they can be considered interesting as antimicrobial drugs on superficial microbial infections.

The essential oil of Salvia desoleana possesses antifungal properties against several mycromycetes. The activity probably derived from the synergistic action between different oil components, since the main components, such as linalyl acetate, 1,8-cineole and linalool, showed a slight antifungal activity [65]. Furthermore, even if it exerted a weak inhibition activity against $S$. aureus, S. epidermidis, E. coli and C. albicans, this inhibition increased progressively with contact time [66].

Both Santolina corsica and Santolina insularis exhibited antimicrobial properties. All studies regarding the first species are referred to as Corsican samples and they documented the antibacterial activity of the essential oil, probably due to the content of lyratol and 1,8-cineol in the oxygenated fraction $[67,68]$. Indeed, these compounds were capable of affecting the integrity of S. aureus plasma membrane and cell wall [69]. The hydrodistillated and supercritical fluid extract of S. insularis exerted antibacterial and antifungal activities against dermatophytes and yeast, especially Cryptococcus neoformans [70,71]. Furthermore, the essential oil decreased the germ tube formation in C. albicans, making it a promising anti-Candida agent [71]. The essential oil was active against some Gram+ bacteria and its effect, probably attributable to artemisia ketone and $\beta$-phellandrene [72], is enhanced by sub-inhibitory concentrations of chitosan [73]. Castangia and coauthors [74] reported that the essential oil of $S$. insularis, incorporated in liposomes, improves its delivery to the skin.

The essential oil of Stachys glutinosa exhibited good bacteriostatic activities against Vibrio cholera, Candida glabrata and Rodotorula rubra clinical strains, and bactericidal activities against the last two yeasts [75]. The hydrodistillated of Tanacetum audibertii exerted antifungal activity against yeasts and dermatophytes strains, especially on C. neoformans [76]. It showed a lower effectiveness against Candida ssp. in the macrodilution broth method, even though an evident inhibitory effect on germ tube formation in C. albicans was observed [76].

The essential oil of Thymus herba-barona subsp. herba-barona was active against Candida ssp., C. neoformans, dermatophytes and Aspergillus ssp. strains, even though it was cytotoxic on macrophages [77]. Due to its ability to inhibit Aspergillus growth, it could be used as a preservative in storage products. The oil was also able to inhibit the growth of a panel of standard reference and 
multiple strains of food-derived spoilage and pathogenic bacteria, due to its content in carvacrol and thymol $[67,78,79]$.

\subsubsection{Antiviral Activity}

The area of infectious diseases has benefited from abundant chemical compounds isolated from plants [80]. Indeed, despite the fact that the number of approved antivirals has considerably increased, these drugs are not always efficacious, and drug-resistant virus strains are rapidly emerging. Our search led to the following seven Sardinian endemic plants endowed with antiviral activities: Euphorbia semiperfoliata, Helichrysum italicum subsp. thyrrenicum, Hypericum hircinum subsp. hircinum, Hypericum scruglii, Limonium morisianum, Salvia desoleana and Santolina insularis. The first five exhibited a significant anti-HIV-1 (Human immunodeficiency virus type 1) activity, acting by different mechanisms of action. Some new jatrophane diterpenes and 4-deoxyphorbol esters isolated from E. semiperfoliata interfered with viral entry by inducing downregulation of HIV receptors in a virus-cell-based assay [81,82]. The same compounds were also able to inhibit the replication of Chikungunya virus (CHIK), probably involving, in both cases, a protein-kinase C-dependent mechanism, despite their different replication strategies [81,82]. The anti-HIV-1 activity of $H$. italicum subsp. thyrrenicum could be attributable to arzanol, which exerted its antiviral activity by inhibiting the transcription nuclear factor-kB (NF-kB), a validated target for inflammation, also involved in several other pathologies, including AIDS (Acquired Immune Deficiency Syndrome) [83]. Some active constituents isolated from H. hircinum subsp. hircinum, such as betulinic acid and two flavanone derivatives, showed a strong inhibition of both DNA polymerase and Ribonuclease $\mathrm{H}$ activities associated to HIV-1 reverse transcriptase (RT) enzyme [84]. In particular, betulinic acid, a triterpene compound already known for its antiviral activity [85], was also active on HIV-1 mutant RTs resistant to efavirenz [84]. Recently, the anti-HIV-1 activity of some phloroglucinol derivatives isolated from aerial parts of $H$. scruglii has been described [86]. In this case, a previously undescribed acylphloroglucinol was able to inhibit the virus replication. Results of time of addition experiments were compatible with an action on RT, while the anti-integrase (IN) activity exhibited in enzymatic assays was not significantly involved in the inhibition of viral replication. The presence of phlorogucinols in $H$. scruglii has confirmed their importance as chemotaxonomic markers of the Hypericum genus [87].

Among the secondary metabolites isolated from L. morisianum, (-)-epigallocatechin 3-O-gallate (EGCg) and myricetin-3-O-(6"-O-galloyl)- $\beta$-d-galactopyranoside potently inhibited both Ribonuclease $\mathrm{H}$ (RNase H) and Integrase (IN) functions in enzymatic assays [88]. The presence of a galloyl moiety in both compounds could explain their anti-HIV-1 activity, according to previous reports [89]. This species was also identified as a potent inhibitor of Ebola virus, since the flavonoid myricetin isolated from its aerial parts was capable of inhibiting the interaction between the viral protein VP35, which plays a fundamental role in the suppression of the host antiviral innate immune response, and the viral double-stranded RNA [90].

The essential oils of $S$. desoleana and $S$. insularis were found to be able to inhibit the herpes simplex virus-2 (HSV-2). In the first case, it inhibited both acyclovir-sensitive and -resistant HSV-2 strains by acting after virus attachment and entry [91]. Differently, the antiviral activity of S. insularis was principally due to a direct inactivation of virions, before its adsorption to host cells [92]. The essential oil of $S$. insularis also inhibited, through the same mechanism of action, the herpes simplex virus-1 (HSV-1). Furthermore, its incorporation in liposomes improved the oil stability and was demonstrated to be effective in inactivating HSV-1 [93].

\subsubsection{Anticancer Activity}

Cancer represents a major undertaking that we are facing on a global health level. In 2018, 18.1 million people all over the world have had cancer, with a mortality rate of 53\%. Unfortunately, these numbers are expected to significantly increase in the next twenty years [94]. Although prevention is indubitably the best approach, there are different lines of attack for cancer treatment, from surgery, radiotherapy, to 
chemotherapy and immunotherapy; unfortunately, they are often accompanied by side effects that have a negative impact on patients, undermining progress towards healing [95]. At present, more than half of the approved antitumor drugs have been isolated from plants and many evidences have demonstrated the potential of plant-derived compounds in both cancer prevention and treatment [96].

Among Sardinian endemic plants, the essential oils of $A$. caerulescens subsp. densiflora and H. italicum subsp. tyrrhenicum were evaluated on human malignant melanoma (A375), breast adenocarcinoma (MDA-MB-231) and colon carcinoma (HCT116) cell lines, exhibiting a concentration-dependent inhibitory effect on all human tumor cells, mainly on A375 [97,98]. Among the volatile compounds isolated from $A$. caerulescens subsp. densiflora, terpinen-4-ol and (E)-nerolidol were previously reported for their cytotoxic activity $[99,100]$, but their concentrations in the oil did not explain the high cytotoxicity observed. Cytotoxic activity of $H$. italicum subsp. thyrrenicum is probably attributable to a synergistic action of various components of the essential oil, since to the best of our knowledge, there is no literature data on the cytotoxicity of the main compounds identified. Arzanol and methylarzanol, the latter obtained by methylation of the pyrone moiety, significantly reduced cancer Caco-2 cells' viability at lower dosages [101]. It is noteworthy that arzanol selectively reduce viability of other several cancer cell lines, suggesting an action as a selective modulator of cell processes typical of cancer cells [101].

Petroleum ether and ethyl acetate extracts from leaves of Bituminaria morisiana showed cytotoxic activity against KB-(HeLa) (KERATIN-forming tumor cell line HeLa) and immunocompetent Jurkat T-cells due to the pterocarpans, especially erybraedin C [102]. The comparison between the activities of all isolated pterocarpans suggested that the prenyl chain at C-8, as well as free hydroxyl groups at positions 3 and 9 in the pterocarpan nucleus, enhanced cytotoxicity [102,103]. Furthermore, the activity of erybraedin $\mathrm{C}$ was not influenced by the overexpression of the mitochondria protecting protein Bcl-2, suggesting that it acts against Jurkat $T$ cells via a mechanism other than the mitochondrial apoptotic pathway. Besides, the cytotoxic activity of this compound seems to be related to an induction of necrosis and not apoptosis [102]. A new prenylated pterocarpan, namely morisianine, obtained from B. morisiana seeds did not show any activity against Jurkat T, HL-60 (human leukemia), CaCo-2 (human epithelial colorectal adenocarcinoma) and MCF-7 (breast cancer) cell lines, up to the highest tested concentration [103].

Three macrocyclic jatrophane polyesters isolated from E. semiperfoliata induced tubulin polymerization into microtubules in vitro and inhibited the growth of some human cancer cell lines influencing p53 expression and Raf-1/Bcl-2 activation. However, differently from paclitaxel, they did not arrest cell cycle in the G2/M (Mitotic gap 2) phase [104].

Some daucane esters from Ferula arrigonii showed antiproliferative activity on several human colon cancer cell lines, in a dose-dependent manner. In particular, a new compound, $2 \alpha-\mathrm{OH}$-ferutidin, and the known ferutidin were the most active ones, followed by lapiferin and jaeskeanadiol [105]. All compounds have been previously reported in this species [106]. 2 $\alpha$-OH-ferutidin was found to be able to induce G0/G1 block into S phase of the cell cycle. Interestingly, this arrest was not followed by cell apoptosis, since the cell growth-inhibitory effect was reversible upon removal of the compound [105]. Moreover, the growth inhibitory potential of daucane esters was found to be positively correlated to their affinities for type II estrogen-binding sites (EBS) [105], which are present in many cancers [107]. In fact, $2 \alpha-\mathrm{OH}$-ferutidin and ferutidin, differently from lapiferin and jaeskeanadiol, were able to interact with type II EBS in WiDr (human colon adenocarcinoma) cells [105].

The alkaloid ungeremine, isolated from the bulbs of P. illyricum, was found to be able to impair both human and bacterial topoisomerases [61], two enzymes present in all living organisms, that control the topology of DNA in all cells and play a role in the cell replication [108]. Therefore, topoisomerases have become important targets for anticancer drugs. Interestingly, ungeremine was capable of incrementing the DNA cleavage stimulated by bacterial topoisomerase IA [61].

Several diacetylenic spiroketal enol ethers identified in the leaves of $P$. flosculosus showed significant cytotoxic activity against Jurkat T and HL-60 leukemia cell lines [109]. The activity was positively correlated with the presence of double bonds in the tetrahydrofuran ring, since compounds containing 
only one were less active. The most active compounds were also able to induce apoptosis in HL-60 cells in a concentration-dependent manner [109].

N-hexane and methanol extracts of Santolina corsica exhibited anti-proliferative activity on uterine cervical (HeLa), alveolar (A549), prostate (PC3), luminal and basal breast (MCF7 and MDA-MB-231) cancer cell lines [110]. This activity could be attibutable to the presence of some compounds, such as $\alpha$-pinene [111] and limonene [112], as well as flavonoids [113], quercetin [114], known for their anti-proliferative effects. It is worth noting that anti-proliferative activities were specific for cancer cells, since neither of the two extracts induced cytotoxicity in the MCF10A non-tumorigenic breast epithelial cell line [110]. Furthermore, both extracts were able to reduce the metastatic capability of MDA-MB-231 breast cancer cells by reducing cells' motility, migration and invasion [110]. Both n-hexane and methanol extracts could induce apoptosis, since after treatment with them, MDA-MB-231 cells changed their morphology, when compared to control cells [115].

Two germacrane sesquiterpenes isolated from $S$. insularis aerial parts showed a potent and selective cytotoxic activity against the human colon carcinoma cell line (Caco-2). In fact, both compounds resulted inactive on peritoneal macrophages [116]. It is worth noting that even though the terpenoid core on cytotoxic sesquiterpene exomethylene $\gamma$-lactones has been recognized to exert a significant role [117], the activity of compounds isolated from S. insularis attested that the sesquiterpene moiety is sufficient to explain the cytotoxic activity.

Ethanol extract of S. glutinosa exhibited a dose-dependent antiproliferative activity on human hepatocarcinoma (HepG2) and breast adenocarcinoma (MCF7) cell lines, while it was less effective against non-tumor muscle cells (C2C12, mouse myoblast), showing a selective activity [118].

The hydroalcoholic extract of $T$. audibertii exerted an interesting antitumor potential against human U2OS osteosarcoma cells [119], by blocking cell population in G2/M phase and affecting the tumor suppressor p53 levels, such as several anticancer agents [120]. Moreover, T. audibertii caused a significant activation of effector caspases [119], suggesting apoptotic cell death [121]. A strong cytotoxicity, also on venous endothelial cells (HUVEC), was recently reported [119], highlighting a potential use in the prevention of angiogenesis, an attractive target for cancer chemotherapy [122].

The essential oil of T. herba-barona subsp. herba-barona exhibited a high toxicity on a mouse macrophage cell line, even at lower concentrations, limiting its potential use for pharmaceutical and cosmetic purposes [77].

In searching for natural compounds with anticancer properties, anti-genotoxic and anti-mutagenic agents must also be considered, along with cytotoxic, anti-proliferative and pro-apoptotic agents. In fact, some anti-genotoxic compounds decrease the side effects associated with the most commonly used anticancer agents $[123,124]$. The flavonoid licoflavone C, isolated from the aerial parts of Genista ephedroides, was able to attenuate the effects of two mutagenic anticancer drugs, namely mitomycin $C$ and daunorubicin, proving to be protective toward the chromosome damage in cultured human peripheral lymphocytes [125]. Licoflavone C, differently from the correspondent non-prenylated flavone apigenin, does not induce genotoxic activity [126], suggesting the key role of the prenyl group at $\mathrm{C}-8$ in the $\mathrm{A}$ ring.

\subsubsection{Antioxidant Activity}

Antioxidants, also called free radical scavengers, are all substances that inhibit oxidation and reduce the occurrence of cancer, diabetes, inflammation, cardiovascular and neurodegenerative diseases [127,128]. In fact, even if free radicals support the immune system, facilitating cell signalling and playing a crucial role in apoptosis, they can damage nucleic acids, proteins, carbohydrates and lipids, leading to several diseases [129]. A wide number of natural antioxidants have been found, such as carotenoids, vitamin E, A, C, phenols and other different compounds [45], and their consumption, as food supplements, results in reduced risk of many diseases.

Some Sardinian endemic species exerted antioxidant activity. The essential oil of A. caerulescens subsp. densiflora was found to be able to protect unsaturated lipids in $\beta$-carotene-linoleate system, 
while it showed only a weak antioxidant activity in the 1,1-diphenyl-2-picrylhydrazyl (DPPH) test [98]. It was also promising as a $\mathrm{ClO}^{-}$scavenger [98].

The antioxidant activity of methanol, petroleum ether and ethyl acetate extracts obtained from the aerial parts of B. morisiana, and three isolated compounds (erybraedin C, bitucarpin A and plicatin B), was investigated in several models of lipid oxidation [130]. Both in linoleic acid and iron-mediated oxidation tests, the ethyl acetate and petroleum ether extracts were the most effective, with respect to the methanol one, which although less effective, still showed an interesting preventive activity [130]. The same extracts also showed a significant inhibition of the cholesterol autoxidation [130]. The ethyl acetate and petroleum ether extracts did not exert cytotoxic activity at antioxidant concentrations $<10 \mathrm{mg} / \mathrm{mL}$, and the methanol one was nontoxic at all concentrations tested. Erybraedin $C$ and plicatin $B$ were capable of protecting linoleic acid against a free radical attack, in a manner superior to that exerted by $\alpha$-tocopherol, highliting a noteworthy antioxidant activity. Erybraedin $C$ was also active against cholesterol autoxidation and oxidative damage induced in VERO (monkey kidney ephitelial) cells by $\mathrm{FeCl}_{3}$ [130]. Instead, bitucarpin A, its deprenyl and dimethyl derivative, was not active, suggesting that two hydroxyl groups in the aromatic ring with prenyl groups in the ortho position are essential for the antioxidant activity [130].

The seeds' oil obtained from E. pithyusa subsp. cupanii and E. semiperfoliata exhibited an interesting antioxidant activity in DPPH and $\beta$-carotene bleaching tests. This activity was significantly correlated with the tocopherol content [131]. Interestingly, E. pithyusa subsp. cupanii, which showed a consistently lower content of $\alpha$-tocopherol than E. semiperfoliata, revealed a higher scavenging activity against DPPH radical, revealing the more important role of $\beta$ - and $\gamma$-tocopherol in scavenging activity in this test.

The presence of flavonoidic compounds, such as luteolin, genistein and 6-hydroxy-genistein in acetonic and ethanolic extracts of aerial parts from Genista cadasonensis, could explain the significant antioxidant activity exhibited in DPPH and 2,2'-azino-bis-3-ethylbenzthiazoline-6-sulphonic acid (ABTS) tests [132].

Methanol extract of $H$. italicum subsp. thyrrenicum possesses a good antioxidant activity, observed in DPPH and $\beta$-carotene bleaching tests [54]. This plant is characterized by various phenolics compounds, such as arzanol and helipirone, which exert a strong protective effect against linoleic acid and cholesterol oxidative degradation. In particular, arzanol caused a concentration-dependent reduction of DPPH similar to the well-known antioxidants such as L-cysteine or ascorbic acid [133] and, at nontoxic concentrations, exerted antioxidant activity also in a cultured cells model [134]. Further studies confirmed its powerful protective effect in lipid peroxidation systems [135]. Arzanol was able to prevent the oxidative damage to human low-density lipoprotein (LDL) and cell membranes [135]. Indeed, pre-treatment with arzanol significantly inhibited the increase of oxidative products, preserving lipoproteins from oxidative damage [135]. Furthermore, it reduced the formation of oxidative products from the degradation of unsaturated fatty acids and cholesterol, exerting, at non-cytotoxic concentrations, a remarkable protection on tert-butyl hydroperoxide (TBH)-induced oxidative damage in Vero and Caco-2 [135]. Interestingly, arzanol accumulates in Caco-2 epithelial cells, and a high rate of diffusion through intestinal cells layers, has been evidenced, suggesting that its antioxidant activity could depend on its bioavalability [135]. Recent studies have highlighted that both the hydroxylated aromatic group and the $\alpha$-pyrone moiety are essential in the peroxyl radical scavenging properties, since the methylation of the pyrone moiety is detrimental for antioxidant activity [101].

H. hircinum subsp. hircinum and H. scruglii extracts exhibited a rather strong antioxidant activity in ABTS, DPPH, FRAP-ferrozine (ferric reducing/antioxidant power) and the $\beta$-carotene bleaching (BCB) tests $[136,137]$. This activity could be attributable to their phenolic components, since a significant linear correlation between this value and the antioxidant activity was observed [136,137].

The supercritical $\mathrm{CO}_{2}$ extract from $S$. desoleana aerial parts exerted, at increasing concentrations, antioxidant activity against $\mathrm{H}_{2} \mathrm{O}_{2}$-induced oxidative stress, on normal (HUVEC) and transformed (ECV304) human endothelial cells, failing to interfere with cell viability [138]. This property can be partially due to the presence of main constituents, especially sclareol, endowed with antioxidative actions [139]. 
Methanol and n-hexane extracts obtained from aerial parts of Santolina corsica revealed an interesting antioxidant activity determined by $\beta$-carotene bleaching, Ferric Reducing Activity Power (FRAP), DPPH and ABTS tests. Generally, the methanol extract was more effective than the n-hexane one [110].

The ethanol extract of $S$. glutinosa was screened by a wide number of assays, revealing a good scavenging activity attributable to polyphenols contents [118].

Methanol extracts from Vinca difformis subsp. sardoa were investigated through DPPH and ABTS assays [140]. Leaves possessed the highest activities, with respect to flowers and roots, probably because of the presence of quinic acid, chlorogenic acid, caffeoylquinic acid isomer and robinin, polyphenols widely recognized for their antioxidant properties [141-143].

\subsubsection{Anti-Inflammatory Activity}

Inflammation is a natural defense mechanism activated by the immune system in response to different chemical, physical or biological factors. However, prolonged and chronic inflammation could be damaging and is a crucial risk factor for heart diseases, atherosclerosis, arthritis, neurodegenerative diseases, metabolic disorders and cancer [144]. Numerous inflammatory mediators such as cytokines, chemokines, eicosanoids and the inflammation-modulating transcription nuclear factor $k \beta(N F-k B)$ are synthetized and secreted during inflammatory responses [145]. Therefore, inhibiting their release or ameliorating the dysregulation of pro-inflammatory and anti-inflammatory cytokines, such as Interleukin-1 $\beta$ (IL-1 $\beta$ ), Interleukin-6 (IL-6), Tumor necrosis factor $\alpha$ (TNF- $\alpha$ ) and Interleukin-10 (IL-10), is a potential strategy for the treatment of inflammation. Current therapies are mainly based on steroidal and non-steroidal drugs and glucocorticoids that, although particularly effective, are not devoid of side effects that limit their use over long periods $[144,146]$. Hence, discovering new anti-inflammatory agents that are potentially non-toxic is urgently required. Among the Sardinian endemic species, five taxa belonging to Asteraceae (Helichrysum italicum subsp. tyrrhenicum, Plagius flosculosus, Santolina corsica and Santolina insularis) and Lamiaceae (Salvia desoleana) exhibited antinflammatory activity.

Arzanol isolated from $H$. italicum subsp. tyrrhenicum, and previously cited for other significant properties, showed powerful NF- $k$ B-inhibiting action [83]. The NF- $k B$ is a validated target for inflammation [147] since it is one of the main regulators of genes involved in the regulation of several factors implicated in inflammatory conditions. Arzanol also showed a potent inhibition of the production of IL- $1 \beta$ and $\mathrm{TNF} \alpha$, pro-inflammatory mediators in primary human monocytes [83]. Furthermore, it inhibited in vitro biosynthesis of eicosanoids, such as 5-lipoxygenase and cyclooxygenase (COX)-1, and also reduced in vivo prostaglandin E2 (PGE2) levels [133].

Ethyl acetate extract and a polyacetylene spiroketal isolated from P. flosculosus inhibited the induction of NF- $k$ B activity. This compound, known as tonghaosu and also found in herb chamomile [148], inhibited the phosphorylation and proteasomal degradation of the IkB protein, preventing the nuclear import and DNA binding of NF- $k \mathrm{~B}$ and interfered with the lipopolysaccharide (LPS)-induced production of IL-1, IL-6, TNF and prostaglandin PGE2 in primary human monocytes [149].

Essential oil from S. desoleana exhibited a good level of inhibition of carrageenan-induced edema, on an in vivo model of anti-inflammatory activity, compared to indomethacin [150].

The essential oil of $S$. corsica, which was characterized by three chemotypes (artemisia ketone, myrcene and $\beta$-phellandrene), exhibited anti-inflammatory activity on the bronchial tract [151]. In fact, when human cells resulted from bronchoalveolar lavage, rich in macrophage-histiocytes, were incubated with the essential oil, the histiocytes restored their ability to phagocytize more material. The addition of the essential oil also produced an evident decrease of granulocytes [151]. The n-hexane extract from the same plant decreased nitric oxide (NO) production and COX-2 levels, showing anti-inflammatory activity [110].

Several flavonoids isolated from S. insularis showed topical anti-inflammatory activity inhibiting croton oil-induced ear edema in mice [152]. Luteolin, according to the literature [153], was the most active compound with a higher reduction of edema with respect to the positive control. A recent 
study demonstrated that pre-treatment with the essential oil of this plant decreased NO production induced by LPS and the expression of iNOS and COX-2, two key enzymes upregulated during fungal infections [71]. Since the oil has no scavenging activity towards NO, it could act via NF- $k \mathrm{~B}$ pathway modulation.

\subsubsection{Anti-Aging Activity}

Skin aging is a natural consequence of structural changes in skin structure and elasticity. It is genetically determined but can also be considerably influenced by environmental factors and lifestyle components [154]. Particularly, the exposure to ultraviolet (UV) light accelerates the ageing of skin, also increasing the risk of dermatological disorders [155]. UV radiation causes the upregulation of matrix metalloproteinases-activating enzymes, such as elastase and tyrosinase, responsible for the deterioration of the dermal extracellular matrix components, thus involved in the skin ageing process as well as in many dermatological diseases [156,157]. Therefore, compounds acting as their inhibitors could be useful as anti-wrinkles and skin-whitening agents. Several plant compounds, endowed with antioxidant properties, have been reported to modulate the activity of these enzymes [158]. Among Sardinian endemic species, Hypericum hircinum subsp. hircinum and Limonium morisianum were able to inhibit both enzymes' activities, while Hypericum scruglii exhibited a selective activity on elastase, suggesting its potential use as an ingredient for anti-wrinkles cosmetics [159]. A positive correlation was established among the enzymatic inhibition and the total phenolic and flavonoid contents [159]. H. hircinum subsp. hircinum and its pure compounds quercetin, caffeoylquinic acids and $5,7,3^{\prime}, 5^{\prime}$-tetrahydroxyflavanone, as well as bulbs extract of $P$. illyricum, were also capable of inhibiting collagenase, another enzyme responsible for the degradation of all components of the extracellular matrix, such as collagen and elastin $[62,136]$.

\subsubsection{Estrogenic/Antiestrogenic Activity}

Phytoestrogens are a group of natural compounds, which have estrogen-like activity [160], with health benefits, such as a lowered risk of heart disease, breast and other hormone-dependent tumors, menopausal symptoms and osteoporosis. Three main categories of phytoestrogens, namely isoflavones, lignans and coumestans, are present in numerous vegetables (most notably soy), fruits and medicinal plants [161], and they are marketed as a natural alternative to estrogen replacement therapy. Nevertheless, phytoestrogens can potentially cause negative health effects, since they could have anti-estrogenic properties, acting as endocrine disruptors [162]. Their activities are due to the structural similarity with $17-\beta$-estradiol, the primary female sex hormone that promotes the interaction with the two main $\alpha$ and $\beta$ estrogen receptors. Consequently, phytoestrogens can act as agonists, partial agonists and antagonists $[160,163]$. Some isoflavones and flavones isolated from the aerial parts of Genista morisii and Genista ephedroides were in vitro evaluated for their estrogenic [164] and anti-estrogenic activities [165] by a yeast-based estrogen receptor assay. The licoflavone C and the isoflavone genistein showed the highest estrogenic activity detected by $\beta$-galactosidase activity induction. The affinity between the licoflavone $C$ and the estrogen receptor $\alpha$ was probably due to the presence of an isoprenyl substituent at ${ }^{8} \mathrm{C}$ [166]. Interestingly, among the active isoflavones (daidzein, genistein, isoprunetin), the estrogenic activity was influenced by glucosilation, since, in general, aglycones were more active than the corresponding glucosides [164]. According to the observation that compounds possessing weak estrogenic activities may exert more appreciable inhibitory action, luteolin, isolated from G. morisii, inhibited the activity of $\beta$-galactosidase mediated by 17 - $\beta$-estradiol, exhibiting anti-estrogenic properties [165]. Differently, licoflavone $C$ acted as an estradiol inhibitor within a concentration range but was estrogenic at higher concentrations. Isoprunetin and isoprunetin 7-glc, that exerted a relatively weak estrogenic action, possessed both agonistic and antagonist activity [165]. 


\subsubsection{Antidiabetic Activity}

Diabetes is one of the largest worldwide health emergencies since it currently affects hundreds of millions of people, with a rising trend [167]. It is due, in 85-90\% of total cases, to the poor or no response of receptors to insulin (type 2 diabetes mellitus), that increase blood glucose levels. Alternatively, type 1 diabetes mellitus, more frequent in children and teenagers, is imputable to the lack or deficiency of insulin, depending on the inability of pancreatic cells to produce it [168]. Diabetes is frequently associated to several complications, most notably cardiovascular and metabolic disorders. One of the therapeutic approaches to treat diabetes consists of the inhibition of carbohydrate-hydrolyzing enzymes (such as $\alpha$-amylase and $\alpha$-glucosidase). The former is responsible for the breakdown of polysaccharides such as starch to monosaccharides [169], the latter breaks down carbohydrates into monosaccharide glucose, allowing its absorption by the intestine [168]. Acarbose, miglitol and voglibose, as well as other synthetic enzyme inhibitors, reduce the absorption rate of glucose, causing a reduction in postprandial glucose levels [170]. However, they are known to produce side effects; therefore, there is an urgent need to search for effective and safer enzyme inhibitors. Several plants have displayed effective inhibitory activity against carbohydrate-hydrolyzing enzymes [171-173].

Among Sardinian endemics, H. hircinum subsp. hircinum, H. scruglii and Limonium contortirameum exhibited antidiabetic properties. Both Hypericum taxa exerted a significant $\alpha$-glucosidase inhibition [137], while Limonium contortirameum was able to inhibit both $\alpha$-amylase and $\alpha$-glucosidase enzymes [174]. Quercetin, identified in these species both as aglycon and glycoside forms, could be responsible, together with other metabolites, for the activity observed, since it is known to reduce blood glucose levels, improving plasma insulin levels [175]. L. contortirameum was also able to inhibit pancreatic triacylglycerol lipase [174], an enzyme important in triacylglycerol breakdown and widely used to determine the potential efficacy of natural products as obesity modulating agents [176]. According to the literature [177], both crude extract and gallic acid isolated from this plant exhibited significant anti-obesity effects.

\subsubsection{Other Activities}

Along with the main biological activities described above, some species also exhibited other peculiar properties. H. hircinum subsp. hircinum also showed cardioprotective and monoamine oxidase (MAO) inhibition properties, confirming that it is one of the most studied Sardinian endemic species. Shah and coauthors [178] described the ability of crude extract obtained from its aerial parts to reduce the cardiotoxicity induced by doxorubicin in rats. This anthracycline glycoside antibiotic is an effective chemotherapeutic drug used for many types of cancer and its toxicity is well-known [179]. The mechanism responsible for doxorubicin-induced cardiotoxicity is the formation of reactive oxygen species (ROS), leading to oxidative stress [180]. Administration of H. hircinum subsp. hircinum in rats induced a decrease of the levels of lipid peroxidative value and marker enzymes, increased the levels of glutathione and superoxide dismutase and prevented the decrease in heart weight in the DOX-treated group [178]. These results may be attributable to its phenolic content and its strong antioxidant activity, as previously reported, suggesting the potential use of this plant as a cardioprotective agent. The positive effect of $H$. scruglii extract against fibromyalgia could also be attributed to the antioxidant activity [181], since the oxidative stress plays a significant role in the pathophysiology of this syndrome. Moreover, the methanol extract and quercetin isolated from H. hircinum subsp. hircinum showed inhibition of monoamine oxidase (MAO) [182], suggesting a potential role in the treatment of neurological disorders. In fact, MAO regulation seems to play a central role in several neurological disorders, such as clinical depression and Parkinson's Disease [183]. Quercetin was also tested to determine the activity towards MAO-A and MAO-B, revealing a selective inhibitory activity against MAO-A [182].

In addition to the previously described anti-inflammatory properties, $S$. desoleana essential oil exherted analgesic properties in an animal model [150]. Interestingly, this oil was able to permeate the 
in vitro porcine buccal mucosa in Franz cells, making possible its use in different formulations, in the stomatological field for its antimicrobial and anti-inflammatory properties [184].

A new galanthamine-type compound, $11 \alpha$-hydroxy-O-methylleucotamine, extracted from the leaves of $P$. illyricum, has shown a good in vitro acetylcholinesterase inhibitory activity, making this plant a potential source of compounds to be employed for the treatment of Alzheimer diseases [185]. Interestingly, leaves (not bulbs) were particulary rich in the active alkaloids; thus, the safeguard of this endemic species could be guaranteed.

The dichloromethane extract and xanthomicrol, the latter a flavone obtained from aerial parts of S. glutinosa, exhibited binding affinity for $\mu$ and $\delta$ opioid receptors. It has also been shown, in an animal model, that pretreatment with xanthomicrol, administered intraperitoneally in mice, significantly inhibited the antinociception induced by morphine in a dose-dependent manner, suggesting an antagonistic effect on $\mu$ opioid receptors [186]. These results acquire considerable value since opioid antagonists are effective in the control of alcohol dependence and several mental pathologies [187,188].

\subsection{Phytoconstituents}

Forty-six endemic plants have been subjected to phytochemical studies and a large variety of phytoconstituents, such as alkaloids, terpenoids, phenolic compounds, saponins, volatile constituents and fatty acids, has been described. A complete list of secondary metabolites identified to date from Sardinian endemic flora is reported in Table 3.

The most studied plant is Helichrysum italicum subsp. tyrrhenicum, with 15 articles highlighting the existence of significant differences in both qualitative and quantitative analyses, especially on essential oils. This high variability, observable also in Artemisia caerulescens subsp. densiflora, Santolina corsica, Santolina insularis and Thymus herba-barona subsp. herba-barona, supported the existence of various chemotypes into these species [46,52,53,97,98,151,189-193]. This chemodiversity could be attributable to genetic and environmental factors [194]. In fact, it is well known that the different geographic localities, seasons, harvest periods, soil properties and climatic conditions strongly affect the phytochemical pattern of plants, especially essential oils. In the case of $H$. italicum subsp. tyrrhenicum, the relationship between climatic variables and chemical compounds of the volatile fraction was recently described, revealing that nerolidol is mostly positively correlated to mean winter temperature, while italicene, bergamotene, nerol and curcumene are positively influenced by spring and summer precipitation [193]. The same authors also established a correlation between essential oils profiles and the altitude, revealing that the content of italicene, $\gamma$-curcumene, ar-curcumene, nerol and geraniol is positively influenced by the altitude, while limonene, caryophyllene, nerolidol and cis- $\beta$-guaiene showed a negative correlation [193].

In addition to genetic and environmental factors, the extraction methods were also shown to induce differences in chemical types or contents in the extracts [45]. Indeed, the yield of some compounds extracted by supercritical fluid extraction (SFE) from Plagius flosculosus, Salvia desoleana, Santolina. insularis, Seseli praecox and Tanacetum audibertii was often different in comparison to that obtained by the hydrodistillation method $[64,70,76,138,195]$.

It is noteworthy that, in some cases, the presence or absence of particular metabolites within congeneric species acquired a chemotaxonomic value. For example, in Genista ssp., despite the presence of aliphatic and unsaturated aldehydes, which represented a common feature, some volatile compounds that were pointed out as a target of single species have been detected: n-heptanal for G. arbusensis, and (E, Z)-2,6-nonadienal for G. corsica [196].

Remarkably, bioprospecting of Sardinian endemic taxa has yielded, along with a high number of known compounds, one-hundred and four previously undescribed metabolites. Out of the new compounds, some are endowed with interesting biological properties $[48,81,82,86,105,185]$. In particular, the highest number of new metabolites has been detected from E. semiperfoliata, E. pithyusa ssp. cupanii and H. italicum subsp. thyrenicum [57,81,82,197-200], as shown in Figure 4. The identification and isolation of original metabolites is worth noting, since they could provide new scaffolds for drug design. 
Table 3. Phytoconstituents isolated from Sardinian endemic species.

\begin{tabular}{|c|c|c|c|c|c|}
\hline Taxon & Type of Extract & Plant Organ & Main Constituents & Voucher Specimen & References \\
\hline \multirow[t]{5}{*}{$\begin{array}{l}\text { Artemisia caerulescens } \\
\text { subsp. densiflora }\end{array}$} & Essential oil & Flowers & Camphor, isoborneol, terpinen-4-ol, camphene & N.A. & [191] \\
\hline & Essential oil & Leaves & $\alpha$-thujone, terpinen-4-ol, camphor & N.A. & [191] \\
\hline & Essential oil & Aerial parts & Terpinen-4-ol, p-cymene, $\mathrm{x}^{\prime \prime \prime}$-terpinene, 1,8-cineole, $\alpha$-terpineol & Herbarium SASSA 736 & [46] \\
\hline & Essential oil & Aerial parts & $\begin{array}{l}\text { Davana ethers, cis-Sabinene hydrate, terpinen-4-ol, (E)-nerolidol, } \\
\beta \text {-Oplopenone }\end{array}$ & Herbarium CAG 736 & [98] \\
\hline & Ethanol extract & Aerial parts & $\begin{array}{l}\alpha / \beta \text { dihydroartemisinin, artemisinin, artemisic acid, absinthin, phytol, } \\
\text { stigmasterol, 3-O--caffeeylquinic acid, caffeic acid, } \\
\text { 3-O-caffeoyl-5-O-feruloylquinic acid, isofraxidin, apigenin, quercetin } \\
\text { 3-methyl ether, eupalitin, luteolin-7-O-methyl ether, axillarin and } \\
\text { cirsimaritin }\end{array}$ & Herbarium CAG 736 & [201] \\
\hline \multirow[t]{4}{*}{ Astragalus verrucosus } & $\begin{array}{l}\text { Ethyl acetate and n-buthanol } \\
\text { extracts }\end{array}$ & Aerial parts & Saponins: astraverrucins I $\mathrm{I}^{* *}, \mathrm{II}{ }^{* *}, \mathrm{III}{ }^{* *}, \mathrm{IV} * *, \mathrm{~V}^{* *}, \mathrm{VI} \mathrm{F}^{* *}$ D-pinitol & URB-96/357 & [202-204] \\
\hline & $\begin{array}{l}\text { Ethyl acetate and n-buthanol } \\
\text { extracts }\end{array}$ & Aerial parts & $\begin{array}{l}\text { Saponins: astraverrucin VII **, cycloaraloside D (peregrinoside II) and } \\
\text { cycloaraloside C (astrailienin A) }\end{array}$ & URB-96/357 & [204] \\
\hline & $\begin{array}{l}\text { Chloroform, ethyl acetate and } \\
\text { n-buthanol extracts }\end{array}$ & Aerial parts & $\begin{array}{l}\text { Flavonoids: Daidzein, genistein, apigenin, apigenin 7-glucoside, } \\
\text { nicotiflorin, rutin, apigenin 7-O- } \beta \text {-D-(6-Op-coumaroyl)glucoside, } \\
\text { kaempferol 3-O-robinobioside, quercetin 3-O-robinobioside, daidzin, } \\
\text { ononin, calycosin, psudobaptigenin, genistin, pratensein }\end{array}$ & URB-96/357 & [204] \\
\hline & $\begin{array}{l}\text { Chloroform, ethyl acetate and } \\
\text { n-buthanol extracts }\end{array}$ & Aerial parts & Pterocarpan derivative: maackiain & URB-96/357 & [204] \\
\hline \multirow{3}{*}{ Bituminaria morisiana } & $\begin{array}{l}\text { Petroleum ether, ethyl acetate } \\
\text { and methanol extracts }\end{array}$ & Aerial parts & Erybraedin C, plicatin B, and bitucarpin A & Herbarium CAG 391/B & [130] \\
\hline & $\begin{array}{l}\text { Petroleum ether and ethyl } \\
\text { acetate extracts }\end{array}$ & Leaves & $\begin{array}{l}\text { Erybraedin C, bitucarpin A, } \\
\text { 3,9-dihydroxy-4-(3,3-dimethyallyl)[6aR,11aR]-pterocarpan **, } \\
\text { 3-hydroxy-4-(3,3-dimethylallyl)-4", }{ }^{*} \text {-dehydropyrano[8,9:2",3"] } \\
\text { [6aR,11aR]-pterocarpan **, } \\
4^{\prime \prime}, 5^{\prime \prime} \text {-dihydroxy-6"-methoxy-4",4"-dimethyl-4",5"-dihydro } \\
-6^{\prime \prime} \text {-p-pyrano[7,8:2",3"]-isoflavone **, daidzein, 8-prenyldaidzein, } \\
\text { bidwillon C, coumestrol, pseudoisopsoralen }\end{array}$ & $\begin{array}{l}\text { Herbarium of Dipartimento } \\
\text { Farmaco Chimico Tecnologico, } \\
\text { University of Cagliari (No. 0201) }\end{array}$ & [102] \\
\hline & Ethyl acetate extract & Seeds & $\begin{array}{l}\text { 3-hydroxy-4-(3'-methyl-2'-butenyl)-furo }\left[2^{\prime}, 3^{\prime}: 8,9\right][6 a \mathrm{R}, 11 \mathrm{aR}] \text { pterocarpan } \\
\text { (morisianine) }{ }^{* *} \text {, erybraedin C, psoralen, angelicin }\end{array}$ & $\begin{array}{l}\text { Herbarium of Dipartimento } \\
\text { Farmaco Chimico Tecnologico, } \\
\text { University of Cagliari (No. 0201) }\end{array}$ & [103] \\
\hline Borago morisiana & Fatty acid methyl esters (FAME) & Seeds & $\gamma$-linoleic and stearidonic acids & $\begin{array}{l}\text { HUAL } 25639 \\
\text { HUAL } 25965\end{array}$ & [206] \\
\hline Borago pygmaea & Fatty acid methyl esters (FAME) & Seeds & $\gamma$-linoleic and stearidonic acids & HUAL 25608 & [206] \\
\hline Centaurea horrida & Methanol extract & Aerial parts & Flavonoid glycoside: horridin ** & URB-3214/97 & [207] \\
\hline
\end{tabular}


Table 3. Cont.

\begin{tabular}{|c|c|c|c|c|c|}
\hline Taxon & Type of Extract & Plant Organ & Main Constituents & Voucher Specimen & References \\
\hline & $\begin{array}{l}\text { N-hexane, chloroform, } \\
\text { chloroform-methanol and } \\
\text { methanol extracts }\end{array}$ & Aerial parts & 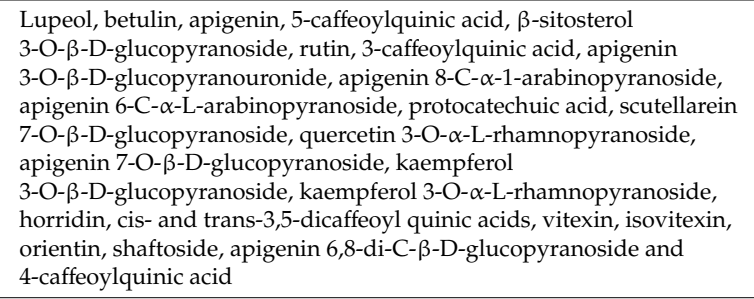 & $\begin{array}{l}\text { Herbarium Horti Botanici Pisani } \\
\text { 03/7219 }\end{array}$ & [208] \\
\hline Cymbalaria muelleri & Ethanol extract & Aerial parts & $\begin{array}{l}\text { Iridoid glycosides: antirrhinoside, antirrhide, macfadienoside, 7- } \beta \\
\text {-hydroxy 8-harpagide }\end{array}$ & N.A. & [209] \\
\hline $\begin{array}{l}\text { Euphorbia hyberna } \\
\text { subsp. insularis }\end{array}$ & Acetone extract & Aerial parts & Jatrophane diterpenoids & N.A. & [210] \\
\hline \multirow[t]{4}{*}{$\begin{array}{l}\text { Euphorbia pithyusa } \\
\text { subsp. cupanii }\end{array}$} & Acetone extract & Aerial parts & 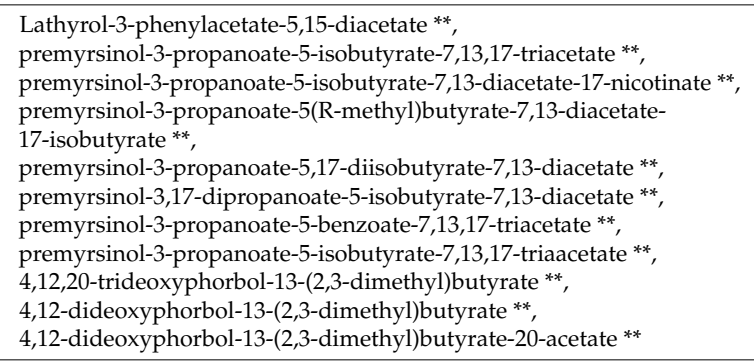 & Herbarium CAG 1212 & [197] \\
\hline & Fatty acid methyl esters (FAME) & Seeds & palmitic acid, stearic acid, oleic acid, linoleic acid, linolenic acid & Herbarium CAG 1212 & [131] \\
\hline & Unsaponifiable fraction & Seeds & $\begin{array}{l}\text { hydrocarbons, fatty alcohols, campesterol, } \beta \text {-sitosterol, } \Delta^{5} \text {-avenasterol, } \\
\text { cycloartanol, } 24 \text {-methylen-cycloartenol }\end{array}$ & Herbarium CAG 1212 & [131] \\
\hline & Tocopherols & Seeds & $\alpha$-tocopherol, $\beta$-tocopherol, $\gamma$-tocopherol, $\delta$-tocopherol & Herbarium CAG 1212 & [131] \\
\hline \multirow[t]{6}{*}{ Euphorbia semiperfoliata } & Ethyl acetate extract * & Whole plant & Eleven Jatrophane esters $* *$, three 4-deoxyphorbol esters ** & & {$[81,82,199]$} \\
\hline & Acetone extract & Aerial parts & $\begin{array}{l}\text { Scopoletin, helioscopinolides A and B, an abietanolide } * *, 13 \text { jatrophane } \\
\text { polyesters } * *, \text { two } 4 \text {-deoxyphorbol diesters } * *, 2 \text { epimeric diterpenes } * *\end{array}$ & Herbarium CAG 1217 & [198] \\
\hline & Acetone extract & Aerial parts & Jatrophane polyesters & N.A. & [104] \\
\hline & Fatty acid methyl esters (FAME) & Seeds & $\begin{array}{l}\text { myristic acid, palmitic acid, stearic acid, oleic acid, linoleic acid, } \\
\text { linolenic acid, arachidic acid, behenic acid }\end{array}$ & Herbarium CAG 1217 & [131] \\
\hline & Unsaponifiable fraction & Seeds & $\begin{array}{l}\text { hydrocarbons, fatty alcohols, cholesterol, campesterol, } \beta \text {-Sitosterol, } \\
\text { lanosterol isomer, lanosterol, } \beta \text {-amyrin, cycloartanol, } \\
\text { 24-Methylen-cycloartenol }\end{array}$ & Herbarium CAG 1217 & [131] \\
\hline & Tocopherols & Seeds & $\alpha$-tocopherol, $\beta$-tocopherol, $\gamma$-tocopherol, $\delta$-tocopherol & Herbarium CAG 1217 & [131] \\
\hline
\end{tabular}


Table 3. Cont

\begin{tabular}{|c|c|c|c|c|c|}
\hline Taxon & Type of Extract & Plant Organ & Main Constituents & Voucher Specimen & References \\
\hline Euphrasia nana & Ethanol extract of aerial parts & Aerial parts & $\begin{array}{l}\text { Iridoid glucosides: aucubin, catalpol, mussaenosidic acid and } \\
\text { melampyroside }\end{array}$ & N.A. & [211] \\
\hline \multirow[t]{3}{*}{ Ferula arrigonii } & N.A. & N.A. & 7,11-dehydrogrilactone ${ }^{*}$ (jalcaguaianolide derivative) & N.A. & [212] \\
\hline & Acetone extract & Roots & $\begin{array}{l}\text { Coumarin derivatives: colladonin, colladin, badrakemone, } \\
\text { umbelliprenin, kataravicinol, isosamarkandin angelate; daucane esters: } \\
\text { ferutidin, lapiferin, } 2 \alpha \text {-Hydroxiferutidin }{ }^{* *}, 2 \text {-oxoferutidin }{ }^{* *} \text {, latifolone }\end{array}$ & N.A. & [106] \\
\hline & Acetone extract & Fruits & $\begin{array}{l}\text { Lapiferin, ferutidin, Jaeskeanadiol veratrate, webbiol angelate, } \\
10 \alpha \text {-hydroxyferutidin, 10-deangeloylpallinin }{ }^{*}, \text { laserin }\end{array}$ & N.A. & [106] \\
\hline Galium corsicum & Ethanol extract & Aerial parts & $\begin{array}{l}\text { Iridoids: asperuloside, monotropein, asperulosidic acid, scandoside, } \\
\text { loganic acid; coumarin }\end{array}$ & Herbarium CAG 652 & [213] \\
\hline Galium glaucophyllum & Ethanol extract & Aerial parts & $\begin{array}{l}\text { Iridoids: asperuloside, monotropein, asperulosidic acid, } \\
\text { deacetyl-asperuloside, geniposidic acid, loganin and loganic acid }\end{array}$ & Herbarium CAG 654 & [213] \\
\hline Galium schmidii & Ethanol extract & Aerial parts & $\begin{array}{l}\text { Iridoids: asperuloside, monotropein, geniposidic acid, loganin and } \\
\text { 10-hydroxy-loganin }\end{array}$ & Herbarium CAG 654/a & [213] \\
\hline Genista arbusensis & Essential oil & Flowers & $\begin{array}{l}\text { Heptanal, 1-octen-3-ol, (E,Z)-2,6-nonadienal, (E)-2-(2-pentenyl)-furan, } \\
\text { 2-penthylfuran, (E)-2-hexenal }\end{array}$ & GA120503NE & [196] \\
\hline Genista bocchierii & Essential oil & Flowers & $\begin{array}{l}\text { Caryophyllene oxide, 1-octen-3-ol, heptanal, } \beta \text {-cariophyllene, } \\
\text { n-pentadecane, (E,Z)-2,6-nonadienal }\end{array}$ & GB240504PU & [196] \\
\hline \multirow[t]{2}{*}{ Genista cadasonensis } & Essential oil & Flowers & $\begin{array}{l}\text { 1-octen-3-ol, (E)-2-(2-pentenyl)-furan, linalool, 2-penthylfuran, } \\
\text { (E,Z)-2,6-nonadienal }\end{array}$ & GD290403CS & [196] \\
\hline & Ethanol extract & Fruits & Pinitol, 3-methoxy-chiro-inositol & Herbarium CAG 290/A & [132] \\
\hline \multirow[t]{4}{*}{ Genista corsica } & Essential oil & Flowers & $\begin{array}{l}\text { (E,Z)-2,6-nonadienal, 1-octen-3-ol, E- } \beta \text {-farnesane, (E)-2-hexenal, } \\
\text { (E)-2-nonenal, mesitylene }\end{array}$ & GC230402CA & [196] \\
\hline & Ethyl acetate extract & Leaves & Daidzein and luteolin & N.A. & [214] \\
\hline & N.A. & N.A. & $\begin{array}{l}\text { Quinolizidine alkaloids: anagyrine, cytisine, N-methylcytisine, } \\
\text { lupanine, retamine and sparteine }\end{array}$ & N.A. & [215] \\
\hline & $\begin{array}{l}\text { N-hexane, choloroform and } \\
\text { methanol extracts }\end{array}$ & Aerial parts & $\begin{array}{l}\text { Dihydroisoderrondiol }{ }^{* *} \text {, daidzein, luteolin, luteolin } 4^{\prime} \text {-O- } \beta \text {-glucoside, } \\
\text { luteolin } 7-\mathrm{O}-\beta \text {-glucoside, isoprunetin, isoderrone, ficuisoflavone, } \\
\text { taxifolin, 5-methoxytaxifolin, sucrose, D-pinitol }\end{array}$ & URB-1742/96 & [216] \\
\hline \multirow[t]{4}{*}{ Genista ephedroides } & $\begin{array}{l}\text { N-hexane, choloroform and } \\
\text { methanol extracts }\end{array}$ & Aerial parts & $\begin{array}{l}\text { Hydroxyalpinumisoflavone }{ }^{* *}, \text { ephedroidin }{ }^{* *}, \text { genisteon } * * \text {, genistein, } \\
\text { isoprunetin, wighteone, laburnetin, alpinumisoflavone, genistin, } \\
\text { genistein 8-C-glucoside, apigenin, isokaempferide, licoflavone C, } \\
\text { pinitol }\end{array}$ & URB-167/94 & [217] \\
\hline & N.A. & N.A. & $\begin{array}{l}\text { Alkaloids: sparteine, lupanine, anagyrine, cytisine, N-methylcytisine, } \\
\text { retamine }\end{array}$ & N.A. & [215] \\
\hline & $\begin{array}{l}\text { N-hexane, choloroform and } \\
\text { methanol extracts }\end{array}$ & Aerial parts & $\begin{array}{l}\text { Alkaloids: lupanine, anagyrine, } 17 \text {-oxoretamine, } \\
12-\alpha \text {-hydroxylupanine, retamine }\end{array}$ & URB-167/94 & [218] \\
\hline & $\begin{array}{l}\text { N-hexane, choloroform and } \\
\text { methanol extracts }\end{array}$ & Aerial parts & Licoflavone C & N.A. & {$[125,164,165]$} \\
\hline
\end{tabular}


Table 3. Cont

\begin{tabular}{|c|c|c|c|c|c|}
\hline Taxon & Type of Extract & Plant Organ & Main Constituents & Voucher Specimen & References \\
\hline \multirow[t]{4}{*}{ Genista morisii } & Essential oil & Flowers & $\begin{array}{l}\text { n-pentacosane, (E)-2-(2-pentenyl)-furan, (E)-2-hexenal, 2-penthylfuran, } \\
(\mathrm{E}, \mathrm{Z})-2,6 \text {-nonadienal, E- } \beta \text {-farnesane }\end{array}$ & GM080403SA & [196] \\
\hline & Hydrolyzed extracts & Leaves & Flavonoids: daidzein, genistein, isoprunetin, luteolin & N.A. & [214] \\
\hline & $\begin{array}{l}\text { N-hexane, choloroform and } \\
\text { methanol extracts }\end{array}$ & Aerial parts & $\begin{array}{l}\text { Flavonoids: Genistein, daidzein, isoprunetin, eriodictyol, } \\
\text { genistein-7-O- } \beta \text {-D-glucopyranoside, isoprunetin } \\
\text { 7-O- } \beta \text {-D-glucopyranoside, vitexin, orientin, luteolin, luteolin } \\
\text { 7-O- } \beta \text {-D-glucopyranoside, isoprunetin } 7,4^{\prime} \\
\text {-di-O- } \beta \text {-D-glucopyranoside, genistein } 7,4^{\prime} \text {-di-O- } \beta \text {-D-glucopyranoside }\end{array}$ & Herbarium SASSA 287 & [219] \\
\hline & $\begin{array}{l}\text { N-hexane, choloroform and } \\
\text { methanol extracts }\end{array}$ & Aerial parts & $\begin{array}{l}\text { Flavonoids: daidzein, genistein, genistein 7-O- } \beta \text {-D-glucopyranoside, } \\
\text { isoprunetin, isoprunetin 7-O- } \beta \text {-D-glucopyranoside, isoprunetin } \\
4^{\prime}, 7-\text {-di-O- } \beta \text {-D-glucopyranoside, luteolin, luteolin } \\
\text { 7-O- } \beta \text {-D-glucopyranoside, luteolin 4'-O- } \beta \text {-D-glucopyranoside }\end{array}$ & N.A. & {$[164,165]$} \\
\hline \multirow[t]{2}{*}{ Genista pichisermolliana } & Essential oil & Flowers & $\begin{array}{l}\beta \text {-myrcene, nerol, (E)-2-(2-pentenyl)-furan, } \gamma \text {-curcumene, linalool, } \\
\text { nonanal, neryl acetate }\end{array}$ & GP130603LA & [196] \\
\hline & $\begin{array}{l}\text { Petroleum ether, chloroform } \\
\text { and methanol extracts }\end{array}$ & Aerial parts & 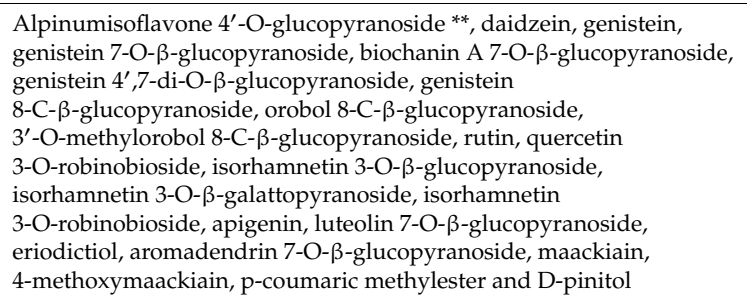 & Herbarium CAG 290/b & [220] \\
\hline \multirow[t]{2}{*}{ Genista sulcitana } & Essential oil & Flowers & $\begin{array}{l}\text { 1-octen-3-ol, (E)-2-hexenal, } \beta \text {-myrcene, (E,Z)-2,6-nonadienal, } \\
\text { (E)-2-(2-pentenyl)-furan, 3-octanol }\end{array}$ & GS090503MV & [196] \\
\hline & Methanol extract & Aerial parts & $\begin{array}{l}\text { luteolin, 7-O-glucoside, genistein 7-O-glucoside, genistein } \\
\text { 8-C-glucoside, p-coumaric acid }\end{array}$ & N.A. & [221] \\
\hline \multirow[t]{2}{*}{ Glechoma sardoa } & Essential oil & Aerial parts & $\beta$-elemene, $\delta$-elemene, $\gamma$-elemene, isogermafurene & URB-GS 165 & [51] \\
\hline & Essential oil & Aerial parts & $\begin{array}{l}\text { germacrene } D, \beta \text {-elemene, isogermafurene, } \delta \text {-elemene, } \beta \text {-phellandrene, } \\
\text { elemol, } \gamma \text {-elemene, } \delta \text {-elemene }\end{array}$ & N.A. & [222] \\
\hline \multirow[t]{5}{*}{$\begin{array}{l}\text { Helichrysum italicum } \\
\text { subsp. tyrrhenicum }\end{array}$} & Essential oil & Aerial parts & $\begin{array}{l}\text { Neryl acetate, nerol, neryl propionate, linalool, rosifoliol, } \gamma \\
\text {-curcumene, } \gamma \text {-cadinene, } \delta \text {-cadinene }\end{array}$ & $\begin{array}{l}\text { Herbarium SASSA } 729[53,192,193] \\
\text { Herbarium CAG } 729[97]\end{array}$ & $\begin{array}{l}52,53,97,192 \\
193,223-226]\end{array}$ \\
\hline & Methanol extract & Aerial parts & $\alpha$-terpinolene, trans-cariophyllene and neryl acetate) & N.A. & [54] \\
\hline & Acetone extract & Aerial parts & $\begin{array}{l}\text { Arzanol (phloroglucinol } \alpha \text {-pyrone), oleyl } \omega \text {-hydroxylinalol, } \\
\text { helipyrone, tremetones, mycropyrone }\end{array}$ & Herbarium CAG 729 & [83] \\
\hline & Acetone extract & Aerial parts & $\begin{array}{l}\text { Arzanol, methylarzanol, helipyrone, micropyrone, rosifoliol, } \\
\text { 10-hydroxytremetone, acetoxytremetone, acetoxyhydroxytremetone }\end{array}$ & N.A. & {$[101,134,135]$} \\
\hline & Acetone extract & Aerial parts & Arzanol & N.A. & [133] \\
\hline
\end{tabular}


Table 3. Cont

\begin{tabular}{|c|c|c|c|c|c|}
\hline Taxon & Type of Extract & Plant Organ & Main Constituents & Voucher Specimen & References \\
\hline & Acetone extract & Aerial parts & $\begin{array}{l}\text { Arzanol, ursolic acid, neryl acetate, } \omega \text {-oleoyloxylinalol, two } \\
\text { O-geranylated isomeric coumarates, helipyrone, oleoylbitalin A**, } \\
\text { nonanoylbitalin } A^{* *} \text {, propanoylbitalin } A^{* *} \text {, isocaproylbitalin } A^{* *}, \text { six } \\
\text { angeloylated lipids (santinols) }{ }^{* *}, \text { micropyrone, heliarzanol } * *\end{array}$ & Herbarium CAG 729/10 & [57] \\
\hline & Acetone extract & Aerial parts & $\begin{array}{l}\text { Micropyrone, arzanol, helipyrone, two acylic derivatives of bitalin A, } \\
\text { gnaphaliol, caffeic acid, ursolic acid, } \\
\text { 7-O- } \beta \text {-(D-glucopyranosyl)-5-methoxy-1(3H)-isobenzofuranone, } \\
\text { gnaphaliol-9-O- } \beta \text {-D-glucopyranoside, } \\
\text { gnaphaliol-3-O- } \beta \text {-D-glucopyranoside, } \\
\text { 6-O- } \beta \text {-(D-glucopyranosyl)-4-methoxy-1(3H)-benzofuranone ** }\end{array}$ & Herbarium CAG 729 & {$[200]$} \\
\hline $\begin{array}{l}\text { Helichrysum saxatile } \\
\text { subsp. saxatile }\end{array}$ & Essential oil & Flowers & $\alpha$-pinene, limonene, 1,8 -cineole, $\gamma$-curcumene. $\beta$-caryophyllene & HMGBH.e/9006.2015.009 & [227] \\
\hline \multirow[t]{3}{*}{$\begin{array}{l}\text { Hypericum hircinum } \\
\text { subsp. hircinum }\end{array}$} & Methanol extract & Leaves & $\begin{array}{l}\text { Quercetin, eriodictyol, 1,6-dihydroxy-5,7-dimethoxyxanthone, } \\
\text { (4R)-4-hydroxy-5,5-dimethyldihydrofuran-2-one, } \\
\text { quercetin-3'-O- } \beta \text {-D-glucopyranoside and } \\
\text { eriodictyol-7-O- } \beta \text {-D-glucopyranoside }\end{array}$ & Herbarium CAG 0201 & [182] \\
\hline & $\begin{array}{l}\text { Hydroalcoholic and ethanol } \\
\text { extracts }\end{array}$ & Aerial parts & $\begin{array}{l}\text { Betulinic acid, shikimic acid, chlorogenic acid, quercetin, } \\
5,7,3^{\prime}, 5^{\prime} \text {-tetrahydroxyflavanone, } \\
5,7,3^{\prime}, 5^{\prime} \text {-tetrahydroxyflavanone-7-O-glucoside }\end{array}$ & Herbarium CAG 232 & {$[84,136]$} \\
\hline & $\begin{array}{l}\text { Hydroalcoholic and ethanol } \\
\text { extracts }\end{array}$ & Aerial parts & $\begin{array}{l}\text { Shikimic acid, chlorogenic acid, quercetin, quercetin-7-O-glucoside, } \\
\text { hypericin }\end{array}$ & Herbarium CAG 232 & [137] \\
\hline \multirow[t]{2}{*}{ Hypericum scruglii } & $\begin{array}{l}\text { Hydro alcoholic and ethanol } \\
\text { extracts }\end{array}$ & Aerial parts & $\begin{array}{l}\text { Shikimic acid, chlorogenic acid, quercitrin, } \\
\text { 3-geranyl-1-(2'-methylbutanoyl)-phloroglucinol, } \\
\text { 3-geranyl-1-(2'-methylpropanoyl)-phloroglucinol, hyperoside, } \\
\text { hypericin }\end{array}$ & Herbarium CAG 239/c & [137] \\
\hline & Hydroalcoholic extract & Leaves & $\begin{array}{l}\text { 3-geranyl-1-(2'-methylbutanoyl)phloroglucinol, } \\
\text { 3-geranyl-1-(2'-methylpropanyl)phloroglucinol, } \\
\text { 3-(13-hydroxygeranyl)-1-(2'-methylbutanoyl)phloroglucinol **, } \\
\text { 1,3,5-benzentriol } \\
\text { 2-(2S,3R)-3-(3,4-dihydroxylphenyl)-2,3-dihydroxylpropyl], } \\
\text { 3,4-dihydroxybenzoic acid and quercitrin }\end{array}$ & Herbarium CAG 239/c & [86] \\
\hline Limonium contortirameum & Aqueous extract & Aerial parts & $\begin{array}{l}\text { Quinic acid, gallic acid, (+)-catechin, quercetin 3-O-[6-(3 } \\
\text { hydroxy-3-methyl-glutaroyl)B-D-galactoside, phlorizin, } \\
\text { epigallocatechin, phloretin, epigallocatechin-3-gallate, } \\
\text { 6"-galloylmyricetin-3-O- } \beta \text {-D-galactopyranoside, } \\
\text { 6"-galloylmyricetin-3-O- } \beta \text {-D-glucoside, quercetin 3,4'-diglucoside, } \\
\text { myricetin 3-O- } \beta \text {-D-glucopyranoside, myricetin 3-O-rhamnoside, } \\
\text { myricetin 3-O-arabinopyranoside, quercetin 3-glucoside, myricetin } \\
\text { 3-O-xylopyranoside, myricetin }\end{array}$ & Herbarium SASSA 909 & [174] \\
\hline \multirow[t]{2}{*}{ Limonium morisianum } & Methanol extract & Aerial parts & $\begin{array}{l}\text { Myricetin, myricetin3-O-rutinoside, } \\
\text { myricetin-3-O-(6"-O-galloyl)- } \beta \text {-D-galactopyranoside, } \\
\text { (-)-epigallocatechin } 3 \text {-O-gallate, tryptamine, ferulic and phloretic acids }\end{array}$ & Herbarium CAG 909/G & [88] \\
\hline & Methanol extract & Aerial parts & Myricetin, (-)-epigallocatechin 3-O-gallate & Herbarium CAG 909/G & [90] \\
\hline
\end{tabular}


Table 3. Cont.

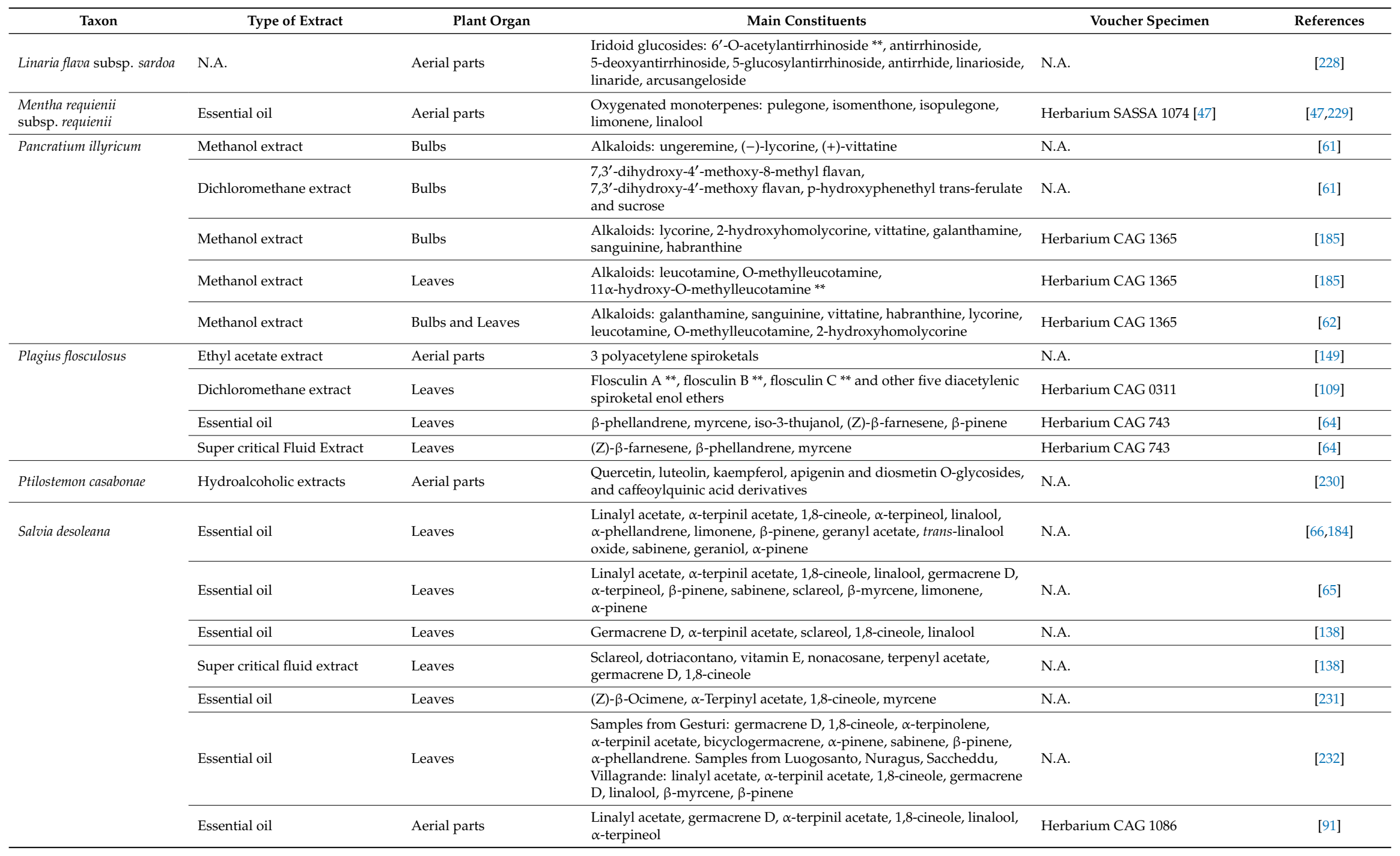


Table 3. Cont

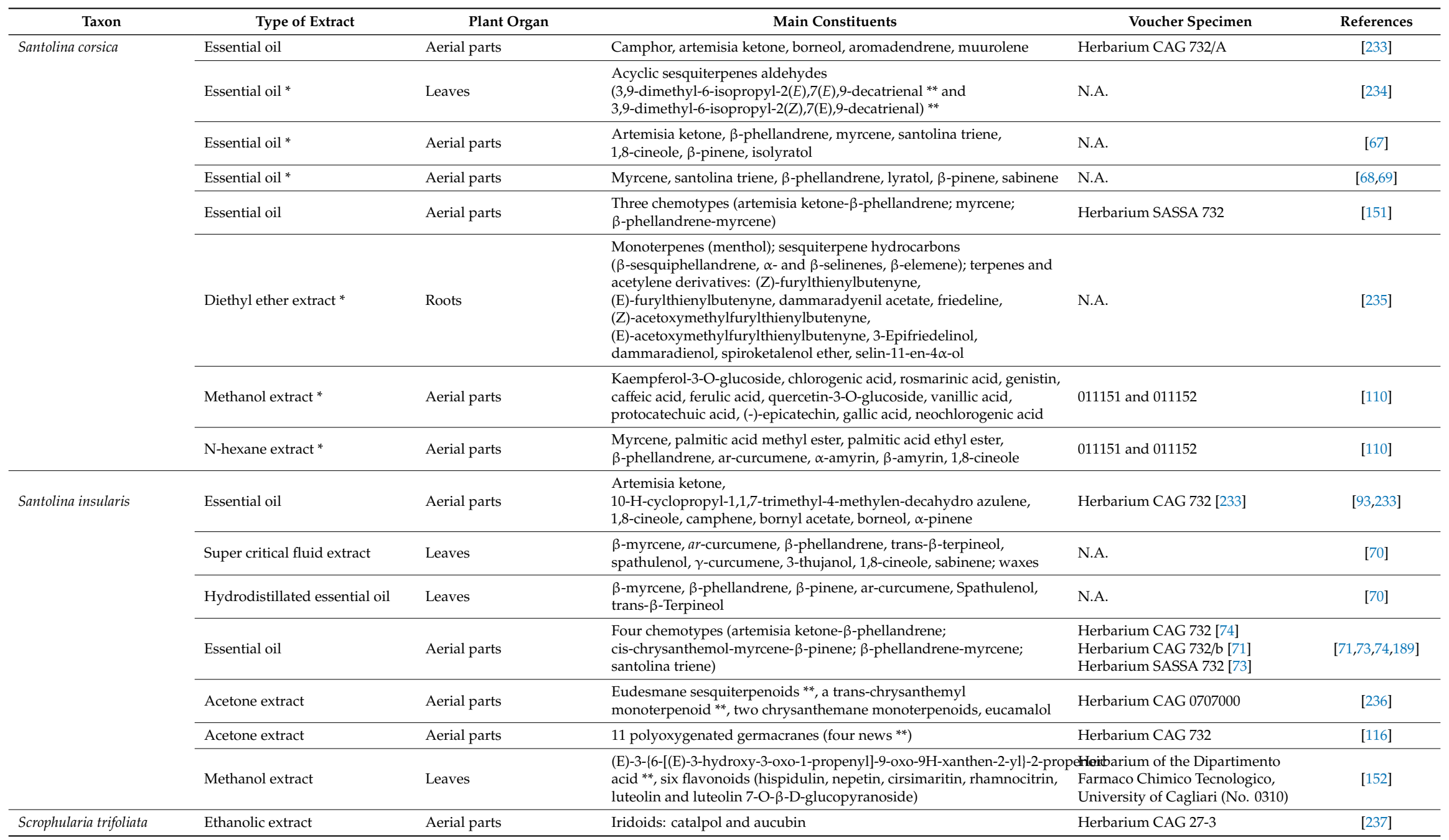


Table 3. Cont

\begin{tabular}{|c|c|c|c|c|c|}
\hline Taxon & Type of Extract & Plant Organ & Main Constituents & Voucher Specimen & References \\
\hline \multirow[t]{3}{*}{ Seseli praecox } & Acetone extract & Aerial parts & $\begin{array}{l}\text { Coumarins: anomalin, isopterixyn, } 3^{\prime} \text {-angeloyl-(-)-cis-khellactone, } \\
\text { bocconin ** }\end{array}$ & N.A. & {$[238]$} \\
\hline & Super critical fluid extract & Leaves & $\begin{array}{l}\text { Differences between three sites (himachalol, sabinene, } \beta \text {-phellandrene; } \\
\beta \text {-phellandrene, undecane, } \alpha \text {-pinene; } \alpha \text {-humulene, } \beta \text {-phellandrene, } \\
\text { bicyclogermacrene) }\end{array}$ & N.A. & [195] \\
\hline & Essential oil & Leaves & $\begin{array}{l}\text { Differences between three sites (sabinene, } \beta \text {-phellandrene; } \\
\beta \text {-phellandrene, } \alpha \text {-pinene; } \alpha \text {-humulene, } \beta \text {-phellandrene, } \\
\text { bicyclogermacrene) }\end{array}$ & N.A. & [195] \\
\hline Stachys corsica & Ethanol extract & Aerial parts & 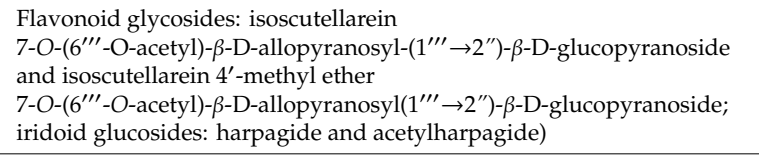 & Herbarium CAG 29-1 [239] & {$[239,240]$} \\
\hline \multirow[t]{5}{*}{ Stachys glutinosa } & Acetone and ethanol extracts & Aerial parts & $\begin{array}{l}\text { Harpagide, 5-Allosyloxy-aucubin **, acetylharpagide, } \\
\text { monomelittoside, melittoside, allobetonicoside }\end{array}$ & N.A. & {$[240,241]$} \\
\hline & Essential oil * & Aerial parts & $\begin{array}{l}\text { Terpinen-4-ol, } \alpha \text {-pinene, } \alpha \text {-terpineol, } \beta \text {-phellandrene and } \gamma \text {-terpinene, } \\
\beta \text {-caryophyllene }\end{array}$ & N.A. & [242] \\
\hline & Essential oil & Aerial parts & $\begin{array}{l}\text { Differences between two sites (terpinen } 4 \text {-ol, } \alpha \text {-terpinyl acetate, } \\
\text { trans-cadina-1(6),4-diene, } \alpha \text {-terpineol; } \alpha \text {-cedrene, } \alpha \text {-terpineol, } \\
\text { terpinen-4-ol, } \alpha \text {-terpinyl acetate) }\end{array}$ & N.A. & [75] \\
\hline & Dichloromethane extract & Aerial parts & $\begin{array}{l}\text { Flavones: xanthomicrol, sideritoflavone, } 8 \text {-methoxycirsilineol and } \\
\text { eupatilin; roseostachenone and } 3 \alpha, 4 \alpha \text {-epoxyroseostachenol }{ }^{* *}\end{array}$ & $\begin{array}{l}\text { Herbarium of the Department of } \\
\text { Life and Environmental Science, } \\
\text { Drug Sciences Section (No. 0425) }\end{array}$ & [186] \\
\hline & Ethanol extract & Aerial parts & 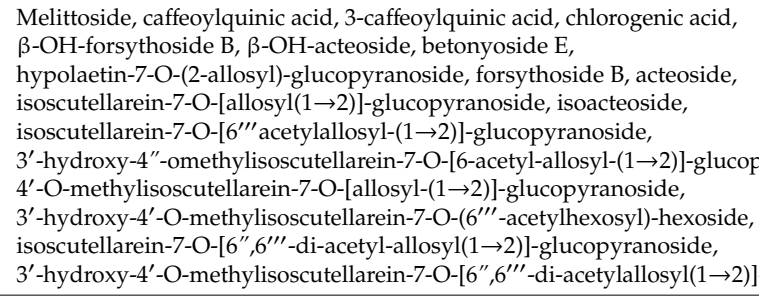 & $\begin{array}{l}\text { Herbarium SASSA } 1099 \\
\text { pyranoside, } \\
\text { ]-glucopyranoside }\end{array}$ & [118] \\
\hline \multirow[t]{3}{*}{ Tanacetum audibertii } & Super critical fluid extract & Aerial parts & $\begin{array}{l}\text { Trans-linalyl oxide acetate, artemisia ketone, 1,8-cineole, artemisyl } \\
\text { acetate }\end{array}$ & Herbarium CAG 737/A & {$[76]$} \\
\hline & Hydrodistillated essential oil & Aerial parts & $\begin{array}{l}\text { Artemisia ketone, trans-linalyl oxide acetate and 1,8-cineole, artemisyl } \\
\text { acetate }\end{array}$ & Herbarium CAG 737/A & {$[76]$} \\
\hline & Hydroalcoholic extract & Aerial parts & $\begin{array}{l}\text { Valine, alanine, aspartic acid, sucrose, } \alpha \text {-glucose. B-glucose, } \\
\text { trigonelline, formic acid. Phenolic and flavonoids contents }\end{array}$ & Herbarium CAG 737/A & [119] \\
\hline
\end{tabular}


Table 3. Cont

\begin{tabular}{|c|c|c|c|c|c|}
\hline Taxon & Type of Extract & Plant Organ & Main Constituents & Voucher Specimen & References \\
\hline \multirow[t]{5}{*}{$\begin{array}{l}\text { Thymus herba-barona } \\
\text { subsp. herba-barona }\end{array}$} & Diethyl ether extract * & Aerial parts & $\begin{array}{l}\text { Flavanones (eriodictyol, naringenin) and flavones (luteolin, sorbifolin, } \\
\text { thymusin, cirsiliol, apigenin, sideritoflavone, cirsimaritin, cirsilineol, } \\
\text { xanthomicrol, 8-methoxycirsilineol and genkwanin) }\end{array}$ & N.A. & [243] \\
\hline & Essential oil * & Aerial parts & $\begin{array}{l}\text { Eight chemotypes (thymol, carvacrol, linalool, geraniol, } \alpha \text {-terpenyl } \\
\text { acetate, terpinen-4-ol, carvone and cis-dihydrocarvone) }\end{array}$ & N.A. & {$[67,190]$} \\
\hline & Essential oil & Aerial parts & $\begin{array}{l}\text { Differences between two sites (thymol, p-cymene, } \gamma \text {-terpinene, linalool; } \\
\text { thymol, carvacrol, p-cymene, } \gamma \text {-terpinene borneol) }\end{array}$ & N.A. & [78] \\
\hline & Essential oil & Aerial parts & Carvacrol, borneol, p-cymene & N.A. & [79] \\
\hline & Essential oil & Aerial parts & Linalool, carvacrol & Herbarium CAG 1065 & [244] \\
\hline $\begin{array}{l}\text { Verbascum conocarpum } \\
\text { subsp. conocarpum }\end{array}$ & Ethanolic extract & Aerial parts & $\begin{array}{l}\text { One iridoid (aucubin) and a phenyl-propanoid compound } \\
\text { (verbascoside) }\end{array}$ & Herbarium CAG 27-2 & [237] \\
\hline \multirow[t]{5}{*}{$\begin{array}{l}\text { Vinca difformis } \\
\text { subsp. sardoa }\end{array}$} & N.A. & Roots & $\begin{array}{l}\text { Alkaloids (norfluorocurarine, akuammigine, carapanaubine, majdine, } \\
\text { isomajdine, rauvoxinine, } \\
\text { ent-N(1)-methyl-14,15-didehydroaspidospermidine } * * \\
\mathrm{~N}(1) \text {-methyl-14,15-didehydroaspidofractinine }{ }^{* *}, \\
\mathrm{~N}(1) \text {-methylaspidofractinine } * * \\
\mathrm{~N}(1) \text {-methyl-14,15-didehydrotuboxenine }{ }^{* *} \text { ) }\end{array}$ & N.A. & [245] \\
\hline & Aqueous acetic acid extract & Aerial parts & $\begin{array}{l}\text { Indole alkaloids (conoflorine, } \\
\mathrm{N}(1) \text {-methyl-14,15-didehydro-12-hydroxyaspidofractinine }{ }^{* *}, \\
\mathrm{~N}(1) \text {-methyl-14,15-didehydro-12-methoxyaspidofractinine }{ }^{* *}, \\
\mathrm{~N}(1) \text {-formyl-14,15-didehydroaspidofractinine } \\
\mathrm{N}(1) \text {-formyl-14,15-didehydro-12-hydroxyaspidofractinine } \\
\text { **, } \\
\text { venalstonine and N(1)-methyl-14,15-didehydroaspidofractinine) }\end{array}$ & N.A. & [246] \\
\hline & Ethanol extract & Aerial parts & Iridoid glucosides (loganic acid and loganin) & N.A. & [247] \\
\hline & Methanolic extract & Leaves & Quinic acid, chlorogenic acid, caffeoylquinic acid isomer 1 and robinin & Herbarium SASSA 820 & [140] \\
\hline & Histochemical preparation & $\begin{array}{l}\text { Roots, stems, petioles, } \\
\text { leaves and flowers }\end{array}$ & Indole alkaloids & Herbarium CAG 1301 [248] & {$[248,249]$} \\
\hline
\end{tabular}

N.A. $=$ information not available; ${ }^{*}$ Samples collected in countries other than Sardinia; ${ }^{* *}$ Compounds isolated for the first time from Sardinian endemic species. 


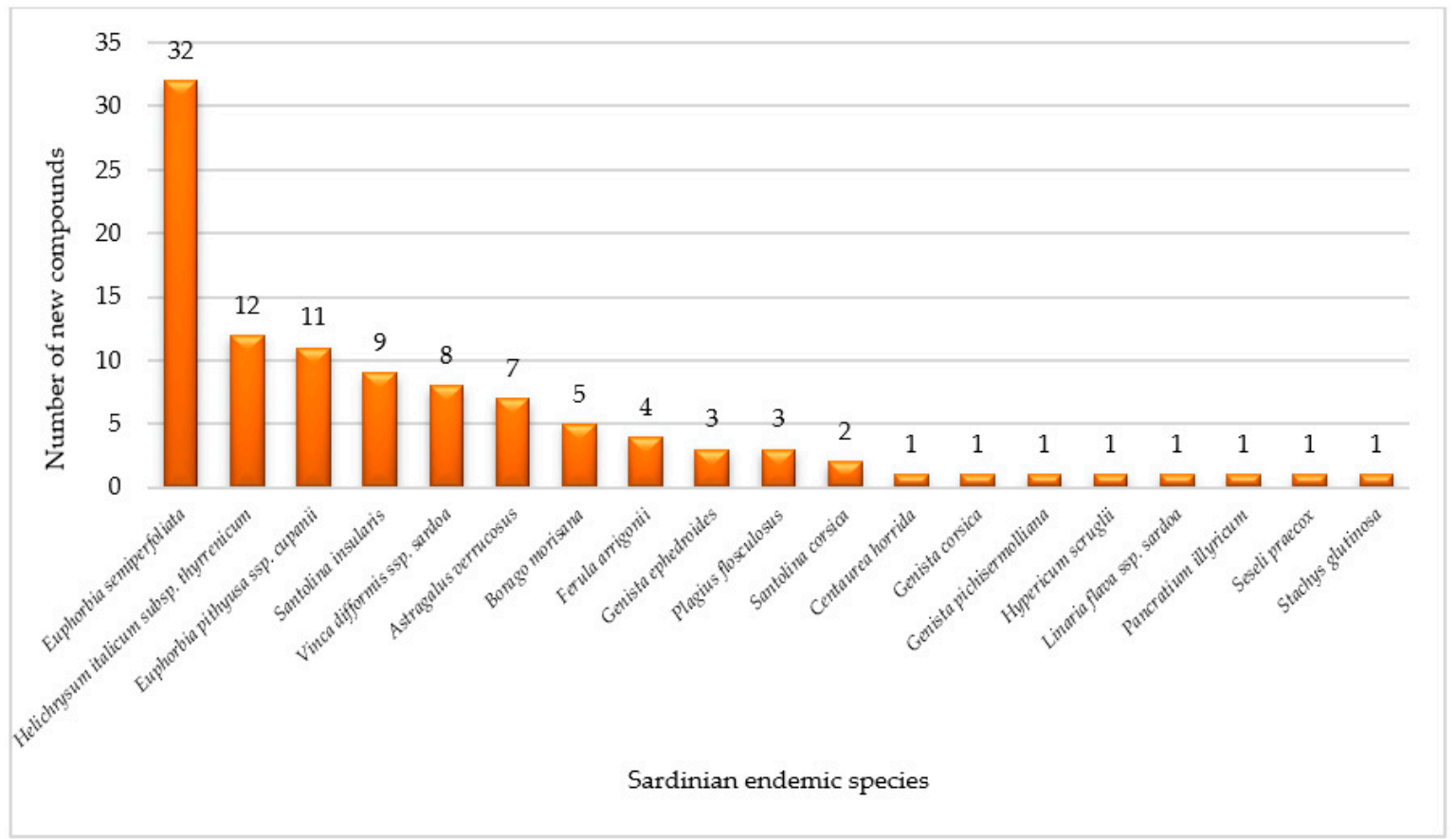

Figure 4. Number of compounds isolated for the first time from Sardinian endemic species $(n=104)$.

\subsection{Criticism and Future Perspectives}

All aforementioned information underlined that Sardinian endemic species could be the inspiration for many valuable therapeutic agents, since they are a rich source of biologically active compounds with unique structures that could contribute toward modern drug discovery. This chemical diversity is the result of a long evolution and adaptation to a wide range of habitats, that have modified the biosynthetic pathways to provide those organisms with a survival advantage in the ecosystems they inhabit [250]. However, the majority of endemic species, which could also represent an economic potential in the identification of new bioactive agents, has not yet been studied. One of the major obstacles arises from the limitations of plant material, especially regarding ecologically rare and endangered species. Indeed, even though small amounts of plant material are usually needed for a preliminar biological evaluation, larger quantities are required for the identification and characterization of bioactive compounds. Considering that a large number of medicinal and aromatic plants utilized all over the world are threatened [251] and two thirds of them are directly collected in the wild, it is necessary to promote and plan a rational exploitation of the plant biodiversity as a source of new bioactive substances. This observation is even more true for the endemic species, since they are particularly sensitive due to their restricted distribution and the small and often fragmented population size [15-17,252-254]. Thus, additional routes for resupply plant material need to be considered and, among the feasible strategies, the ex situ cultivation of threatened medicinal plants represents an encouraging protective approach in order to reconcile the conservation needs with research in the pharmaceutical field $[19,255]$. This approach may be pursued for endemic plants that require conservation efforts to prevent or mitigate the extinction risk. As recently demonstrated, the multiplication in nursery for several Mediterranean threatened endemic plants was an easy procedure, not cost-expensive and a practicable solution to obtain a large number of new individuals for several uses $[16,256]$.

In addition to their ex situ cultivation, biotechnological strategies could also be pursued for the preservation and sustainable valorization of endemic plants, as well as their economic development [257]. Indeed, biotechnologies allow for producing bioactive molecules through in vitro cultivation or micropropagation of valuable species, as is well-documented by Giamperi and coauthors [222] for Glechoma sardoa. 


\section{Conclusions}

This review provided, for the first time, an up-to-date and comprehensive overview on ethnobotanical uses, biological properties and phytoconstituents of Sardinian endemic plants, with the aim to supply input for future research prospects. Taking into account our results, only $17 \%$ of Sardinian endemic species have been subjected to phytochemical and/or pharmacological evaluation, with a great potential in the pharmaceutical field. Many of these exhibited significant antimicrobial, antinflammatory, antiviral, antioxidant and anticancer properties, even though these properties are not correlated to their traditional uses. Indeed, our literature survey pointed out that the selection of endemic plants for extract screening has probably been achieved by chemotaxonomic and biodiversity-driven approaches. Besides species intensively studied, such as Helichrysum italicum subsp. thyrrenicum, Santolina insularis, Hypericum hircinum subsp. hircinum and Salvia desoleana, there are many others deserving of attention and in-depth evaluation. They represent a great source of phytoconstituents, often unique and structurally diverse, due to adaptation to the local environment. It is worth noting that, in spite of their great value as sources of bioactive compounds, the majority of Sardinian endemic species have not been investigated, representing a potential to be explored in the identification of new bioactive agents. However, endemic species are often threatened and vulnerable, due to their rareness, and thus they need to be conserved and protected. One of the major critical issues in studying endemic species is represented by the limited availability of plant material necessary for biological evaluation and characterization of bioactive compounds. Therefore, additional strategies, such as ex situ or in vitro cultivation, need to be considered in order to reconcile the safeguard interest with research in the pharmaceutical field.

Supplementary Materials: The following are available online at http://www.mdpi.com/2223-7747/9/8/958/s1: Table S1: Biological activities of Sardinian endemic species.

Author Contributions: Conceptualization, C.S. and M.C.L.; resources, C.S., G.F. and M.C.L.; data curation, C.S., A.M., G.F. and M.C.L.; writing-original draft preparation, C.S. and M.C.L.; writing—review and editing, C.S., M.C.L., A.M. and G.F.; supervision, C.S. All authors have read and agreed to the published version of the manuscript.

Funding: This research received no external funding. The APC was funded by Co.S.Me.Se, Consorzio per lo Studio dei Metaboliti Secondari, Cagliari (Italy).

Acknowledgments: The authors are grateful to Co.S.Me.Se, Consorzio per lo Studio dei Metaboliti Secondari, Cagliari (Italy), for administrative and technical support.

Conflicts of Interest: The authors declare no conflict of interest.

\section{References}

1. Kinghorn, A.D.; Pan, L.; Fletcher, J.N.; Chai, H. The relevance of higher plants in lead compound discovery programs. J. Nat. Prod. 2011, 74, 1539-1555. [CrossRef] [PubMed]

2. Newman, D.J.; Cragg, G.M. Natural Products as Sources of New Drugs from 1981 to 2014. J. Nat. Prod. 2016, 79, 629-661. [CrossRef] [PubMed]

3. Atanasov, A.G.; Waltenberger, B.; Pferschy-Wenzig, E.M.; Linder, T.; Wawrosch, C.; Uhrin, P.; Temml, V.; Wang, L.; Schwaiger, S.; Heiss, E.H.; et al. Discovery and resupply of pharmacologically active plant-derived natural products: A review. Biotechnol. Adv. 2015, 33, 1582-1614. [CrossRef]

4. Li, J.W.-H.; Vederas, J.C. Drug Discovery and Natural Products: End of an Era or an Endless Frontier? Science 2009, 325, 161-165. [CrossRef] [PubMed]

5. David, B.; Wolfender, J.-L.; Dias, D.A. The pharmaceutical industry and natural products: Historical status and new trends. Phytochem. Rev. 2015, 14, 299-315. [CrossRef]

6. Thomford, N.E.; Senthebane, D.A.; Rowe, A.; Munro, D.; Seele, P.; Maroyi, A.; Dzobo, K. Natural products for drug discovery in the 21st century: Innovations for novel drug discovery. Int. J. Mol. Sci. 2018, 19, 1578. [CrossRef]

7. Verpoorte, R. Pharmacognosy in the New Millennium: Leadfinding and Biotechnology. J. Pharm. Pharmacol. 2000, 52, 253-262. [CrossRef] 
8. Aumeeruddy-Elalfi, Z.; Gurib-Fakim, A.; Mahomoodally, F. Antimicrobial, antibiotic potentiating activity and phytochemical profile of essential oils from exotic and endemic medicinal plants of Mauritius. Ind. Crops Prod. 2015, 71, 197-204. [CrossRef]

9. Neergheen, V.S.; Soobrattee, M.A.; Bahorun, T.; Aruoma, O.I. Characterization of the phenolic constituents in Mauritian endemic plants as determinants of their antioxidant activities in vitro. J. Plant Physiol. 2006, 163, 787-799. [CrossRef]

10. Neergheen, V.S.; Bahorun, T.; Jen, L.S.; Aruoma, O.I. Bioefficacy of mauritian endemic medicinal plants: Assessment of their phenolic contents and antioxidant potential. Pharm. Biol. 2007, 45, 9-17. [CrossRef]

11. Rangasamy, O.; Mahomoodally, F.M.; Gurib-Fakim, A.; Quetin-Leclercq, J. Two anti-staphylococcal triterpenoid acids isolated from Psiloxylon mauritianum (Bouton ex Hook.f.) Baillon, an endemic traditional medicinal plant of Mauritius. S. Afr. J. Bot. 2014, 93, 198-203. [CrossRef]

12. Soobrattee, M.A.; Bahorun, T.; Neergheen, V.S.; Googoolye, K.; Aruoma, O.I. Assessment of the content of phenolics and antioxidant actions of the Rubiaceae, Ebenaceae, Celastraceae, Erythroxylaceae and Sterculaceae families of Mauritian endemic plants. Toxicol. Vitr. 2008, 22, 45-56. [CrossRef] [PubMed]

13. Cañadas, E.M.; Fenu, G.; Peñas, J.; Lorite, J.; Mattana, E.; Bacchetta, G. Hotspots within hotspots: Endemic plant richness, environmental drivers, and implications for conservation. Biol. Conserv. 2014, 170, $282-291$. [CrossRef]

14. Mittermeier, R.A.; Robles Gil, P.; Hoffman, M.; Pilgrim, J.; Brooks, T.; Mittermeier, C.G.; Lamoreux, J.; da Fonseca, G.A. Hotspots Revisited: Earth's Biologically Richest and Most Endangered Terrestrial Ecoregions; University of Chicago Press: Chicago, IL, USA, 2005.

15. Médail, F. The specific vulnerability of plant biodiversity and vegetation on Mediterranean islands in the face of global change. Reg. Environ. Chang. 2017, 17, 1775-1790. [CrossRef]

16. Fenu, G.; Bacchetta, G.; Christodoulou, C.S.; Cogoni, D.; Fournaraki, C.; del Galdo Gian Pietro, G.; Gotsiou, P.; Kyratzis, A.; Piazza, C.; Vicens, M.; et al. A common approach to the conservation of threatened island vascular plants: First results in the mediterranean basin. Diversity 2020, 12, 157. [CrossRef]

17. Thompson, J.D. Plant Evolution in the Mediterranean; Oxford University Press: Oxford, UK, 2005; ISBN 0198515332.

18. Fenu, G.; Fois, M.; Cañadas, E.M.; Bacchetta, G. Using endemic-plant distribution, geology and geomorphology in biogeography: The case of Sardinia (mediterranean basin). Syst. Biodivers. 2014, 12, 181-193. [CrossRef]

19. Fenu, G.; Giusso Del Galdo, G.; Montmollin De, B.; Gotsiou, P.; Cogoni, D.; Piazza, C.; Fournaraki, C.; Kyratzis, A.C.; Vicens, M.; Christodoulou, C.S.; et al. Active management actions for the conservation of the endangered Mediterranean island flora: The CARE-MEDIFLORA project. Plant Sociol. 2017, 54, 101-110. [CrossRef]

20. Bartolucci, F.; Peruzzi, L.; Galasso, G.; Albano, A.; Alessandrini, A.; Ardenghi, N.M.G.; Astuti, G.; Bacchetta, G.; Ballelli, S.; Banfi, E.; et al. An updated checklist of the vascular flora native to Italy. Plant Biosyst. 2018, 152, 179-303. [CrossRef]

21. Lussu, M.; Marignani, M.; Lai, R.; Loi, M.C.; Cogoni, A.; Cortis, P. A Synopsis of Sardinian Studies: Why Is It Important to Work on Island Orchids? Plants 2020, 9, 853. [CrossRef]

22. Bacchetta, G.; Fenu, G.; Guarino, R.; Mandis, G.; Mattana, E.; Nieddu, G.; Scudu, C. Floristic traits and biogeographic characterization of the Gennargentu massif (Sardinia). Candollea 2013, 68, 209-220. [CrossRef]

23. Fenu, G.; Mattana, E.; Congiu, A.; Bacchetta, G. The Endemic Vascular Flora of Supramontes (Sardinia), a Priority Plant Conservation Area. Candollea 2010, 65, 347-358. [CrossRef]

24. Sanna, C.; Ballero, M.; Frailis, L. Bibliografia etnobotanica italiana. Rend. Semin. Fac. Sci. Univ. Cagliari 2007, 77, 31-70.

25. Leonti, M.; Casu, L.; Sanna, F.; Bonsignore, L. A comparison of medicinal plant use in Sardinia and Sicily-De Materia Medica revisited? J. Ethnopharmacol. 2009, 121, 255-267. [CrossRef] [PubMed]

26. Stepp, J.R.; Moerman, D.E. The importance of weeds in ethnopharmacology. J. Ethnopharmacol. 2001, 75, 19-23. [CrossRef]

27. Loi, M.; Frailis, L.; Maxia, A. Le piante utilizzate nella medicina popolare nel territorio di Gesturi (Sardegna centro-meridionale). Atti Soc. Toscana Sci. Nat. Mem. Ser. B 2002, 109, 167-176.

28. Ballero, M.; Poli, F. Plants used in folk medicine of Monteleone (northern Sardinia). Fitoterapia 1998, 69, 52-64. 
29. Ballero, M.; Floris, R.; Poli, F. Le piante utilizzate nella medicina popolare nel territorio di Laconi (Sardegna centrale). Boll. Soc. Sarda Sci. Nat. 1997, 31, 207-229.

30. Atzei, A.D. Le Piante Nella Tradizione Popolare Della Sardegna; Carlo Delfino Editore: Sassari, Italy, 2003.

31. Fabricant, D.S.; Farnsworth, N.R. The value of plants used in traditional medicine for drug discovery. Environ. Health Perspect. 2001, 109, 69-75. [CrossRef]

32. Ballero, M.; Fresu, I. Le piante di uso officinale nella Barbagia di Seui (Sardegna centrale). Fitoterapia 1993, 64, 141-150.

33. Sanna, C.; Ballero, M.; Maxia, A. Le piante medicinali utilizzate contro le patologie epidermiche in Ogliastra (Sardegna centro-orientale). Atti Soc. Toscana Sci. Nat. Mem. Ser. B 2006, 113, 73-82.

34. Bruni, A.; Ballero, M.; Poli, F. Quantitative ethnopharmacological study of the Campidano Valley and Urzulei district, Sardinia, Italy. J. Ethnopharmacol. 1997, 57, 97-124. [CrossRef]

35. Loi, M.C.; Poli, F.; Sacchetti, G.; Selenu, M.B.; Ballero, M. Ethnopharmacology of Ogliastra (Villagrande Strisaili, Sardinia, Italy). Fitoterapia 2004, 75, 277-295. [CrossRef] [PubMed]

36. Ballero, M.; Bruni, A.; Sacchetti, G.; Poli, F. Le piante utilizzate nella medicina popolare nel comune di Tempio Pausania (Sardegna settentrionale). Acta Phyther. 1997, 2, $23-29$.

37. Ballero, M.; Poli, F.; Sacchetti, G.; Loi, M.C. Ethnobotanical research in the territory of Fluminimaggiore (south-western Sardinia). Fitoterapia 2001, 72, 788-801. [CrossRef]

38. Loi, M.C.; Maxia, L.; Maxia, A. Ethnobotanical comparison between the villages of Escolca and Lotzorai (Sardinia, Italy). J. Herbs Spices Med. Plants 2005, 11, 67-84. [CrossRef]

39. Ballero, M.; Bruni, A.; Sacchetti, G.; Poli, F. Indagine etnofarmacobotanica del territorio di Arzana (Sardegna orientale). Ann. Bot. 1994, 52, 489-500.

40. Ballero, M.; Fresu, I. Le piante officinali impiegate nel territorio del Marganai (Sardegna sud-occidentale). Fitoterapia 1991, 62, 524-531.

41. Ballero, M.; Sacchetti, G.; Poli, F. Plants in folk medicine in the territory of Perdasdefogu (Central Sardinia, Italy). Allionia 1997, 35, 157-164.

42. Ballero, M.; Floris, R.; Sacchetti, G.; Poli, F. Ricerche etnobotaniche nel comune di Ussassai (Sardegna Centro-Orientale). Atti Della Soc. Toscana Sci. Nat. Mem. Ser. B 1998, 105, 83-87.

43. Mattalia, G.; Sõukand, R.; Corvo, P.; Pieroni, A. Wild Food Thistle Gathering and Pastoralism: An Inextricable Link in the Wild Food Thistle Gathering and Pastoralism: An Inextricable Link in the Biocultural Landscape of Barbagia, Central Sardinia (Italy). Sustainability 2020, 12, 5105. [CrossRef]

44. World Health Organization. Antimicrobial Resistance and Primary Health Care; World Health Organization: Geneva, Switzerland, 2018.

45. Altemimi, A.; Lakhssassi, N.; Baharlouei, A.; Watson, D.G.; Lightfoot, D.A. Phytochemicals: Extraction, isolation, and identification of bioactive compounds from plant extracts. Plants 2017, 6, 42. [CrossRef]

46. Petretto, G.L.; Chessa, M.; Piana, A.; Masia, M.D.; Foddai, M.; Mangano, G.; Culeddu, N.; Afifi, F.U.; Pintore, G. Chemical and biological study on the essential oil of Artemisia caerulescens L. ssp. densiflora (Viv.). Nat. Prod. Res. 2013, 27, 1709-1715. [CrossRef] [PubMed]

47. Chessa, M.; Sias, A.; Piana, A.; Mangano, G.S.; Petretto, G.L.; Masia, M.D.; Tirillini, B.; Pintore, G. Chemical composition and antibacterial activity of the essential oil from Mentha requienii Bentham. Nat. Prod. Res. 2013, 27, 93-99. [CrossRef] [PubMed]

48. Pistelli, L.; Bertoli, A.; Lepori, E.; Morelli, I.; Panizzi, L. Antimicrobial and antifungal activity of crude extracts and isolated saponins from Astragalus verrucosus. Fitoterapia 2002, 73, 336-339. [CrossRef]

49. Aboody, M.S.A.; Mickymaray, S. Anti-fungal efficacy and mechanisms of flavonoids. Antibiotics 2020, 9, 45. [CrossRef]

50. Esposito, M.; Nim, S.; Nothias, L.F.; Gallard, J.F.; Rawal, M.K.; Costa, J.; Roussi, F.; Prasad, R.; Di Pietro, A.; Paolini, J.; et al. Evaluation of Jatrophane Esters from Euphorbia spp. as Modulators of Candida albicans Multidrug Transporters. J. Nat. Prod. 2017, 80, 479-487. [CrossRef]

51. Usai, M.; Juliano, C.; Pintore, G.; Chessa, M. Preliminarly study of composition and antimicrobial activity of essential oil of Glechoma sardoa Bég. Acta Hortic. 2004, 597, 125-128. [CrossRef]

52. Angioni, A.; Barra, A.; Arlorio, M.; Coisson, J.D.; Russo, M.T.; Pirisi, F.M.; Satta, M.; Cabras, P. Chemical composition, plant genetic differences, and antifungal activity of the essential oil of Helichrysum italicum G. Don ssp. microphyllum (Willd) Nym. J. Agric. Food Chem. 2003, 51, 1030-1034. [CrossRef] 
53. Juliano, C.; Marchetti, M.; Campagna, P.; Usai, M. Antimicrobial activity and chemical composition of essential oil from Helichrysum microphyllum Cambess. subsp. tyrrhenicum Bacch., Brullo \& Giusso collected in South-West Sardinia. Saudi J. Biol. Sci. 2019, 26, 897-905. [CrossRef]

54. Tundis, R.; Statti, G.A.; Conforti, F.; Bianchi, A.; Agrimonti, C.; Sacchetti, G.; Muzzoli, M.; Ballero, M.; Menichini, F.; Poli, F. Influence of environmental factors on composition of volatile constituents and biological activity of Helichrysum italicum (Roth) Don (Asteraceae). Nat. Prod. Res. 2005, 19, 379-387. [CrossRef]

55. Chinou, I.B.; Roussis, V.; Perdetzoglou, D.; Loukis, A. Chemical and biological studies on two Helichrysum species of Greek origin. Planta Med. 1996, 62, 377-379. [CrossRef]

56. Roussis, V.; Tsoukatou, M.; Chinou, I.B.; Ortiz, A. Composition and Antibacterial Activity of Two Helichrysum Species of Greek Origin. Planta Med. 1997, 63, 181-183.

57. Taglialatela-Scafati, O.; Pollastro, F.; Chianese, G.; Minassi, A.; Gibbons, S.; Arunotayanun, W.; Mabebie, B.; Ballero, M.; Appendino, G. Antimicrobial phenolics and unusual glycerides from Helichrysum italicum subsp. microphyllum. J. Nat. Prod. 2013, 76, 346-353. [CrossRef]

58. Marshall, N.J.; Piddock, L.J. Antibacterial efflux systems. Microbiologia 1997, 13, 285-300. [PubMed]

59. Donadu, M.G.; Usai, D.; Marchetti, M.; Usai, M.; Mazzarello, V.; Molicotti, P.; Montesu, M.A.; Delogu, G.; Zanetti, S. Antifungal activity of oils macerates of North Sardinia plants against Candida species isolated from clinical patients with candidiasis. Nat. Prod. Res. 2019, 1-5. [CrossRef]

60. Mandrone, M.; Bonvicini, F.; Lianza, M.; Sanna, C.; Maxia, A.; Gentilomi, G.A.; Poli, F. Sardinian plants with antimicrobial potential. Biological screening with multivariate data treatment of thirty-six extracts. Ind. Crops Prod. 2019, 137, 557-565. [CrossRef]

61. Casu, L.; Cottiglia, F.; Leonti, M.; De Logu, A.; Agus, E.; Tse-Dinh, Y.C.; Lombardo, V.; Sissi, C. Ungeremine effectively targets mammalian as well as bacterial type i and type II topoisomerases. Bioorg. Med. Chem. Lett. 2011, 21, 7041-7044. [CrossRef]

62. Bonvicini, F.; Antognoni, F.; Iannello, C.; Maxia, A.; Poli, F.; Gentilomi, G.A. Relevant and selective activity of Pancratium illyricum L. against Candida albicans clinical isolates: A combined effect on yeast growth and virulence. BMC Complement. Altern. Med. 2014, 14, 409. [CrossRef]

63. Ghosal, S.; Singh, S.K.S.; Kumar, Y.; Unnikrishnan, S.; Chattopadhyay, S. The role of ungeremine in the growth-inhibiting and cytotoxic effects of lycorine: Evidence and speculation. Planta Med. 1988, 54, 114-116. [CrossRef]

64. Marongiu, B.; Piras, A.; Porcedda, S.; Tuveri, E.; Laconi, S.; Deidda, D.; Maxia, A. Chemical and biological comparisons on supercritical extracts of Tanacetum cinerariifolium (Trevir) Sch. Bip. with three related species of chrysanthemums of Sardinia (Italy). Nat. Prod. Res. 2009, 23, 190-199. [CrossRef]

65. Soković, M.D.; Brkić, D.D.; Džamić, A.M.; Ristić, M.S.; Marin, P.D. Chemical composition and antifungal activity of Salvia desoleana Atzei \& Picci essential oil and its major components. Flavour Fragr. J. 2009, 24, 83-87. [CrossRef]

66. Peana, A.T.; Moretti, M.D.L.; Juliano, C. Chemical composition and antimicrobial action of the essential oils of Salvia desoleana and S. sclarea. Planta Med. 1999, 65, 752-754. [CrossRef] [PubMed]

67. Rossi, P.G.; Berti, L.; Panighi, J.; Luciani, A.; Maury, J.; Muselli, A.; Serra, D.D.R.; Gonny, M.; Bolla, J.M. Antibacterial action of essential oils from Corsica. J. Essent. Oil Res. 2007, 19, 176-182. [CrossRef]

68. Liu, K.; Rossi, P.-G.; Ferrari, B.; Berti, L.; Casanova, J.; Tomi, F. Composition, irregular terpenoids, chemical variability and antibacterial activity of the essential oil from Santolina corsica Jordan et Fourr. Phytochemistry 2007, 68, 1698-1705. [CrossRef] [PubMed]

69. Guinoiseau, E.; Luciani, A.; Rossi, P.G.; Quilichini, Y.; Ternengo, S.; Bradesi, P.; Berti, L. Cellular effects induced by Inula graveolens and Santolina corsica essential oils on Staphylococcus aureus. Eur. J. Clin. Microbiol. Infect. Dis. 2010, 29, 873-879. [CrossRef]

70. Cherchi, G.; Deidda, D.; Gioannis, B.D.; Marongiu, B.; Pompei, R.; Porcedda, S. Extraction of Santolina insularis essential oil by supercritical carbon dioxide: Influence of some process parameters and biological activity. Flavour Fragr. J. 2001, 16, 35-43. [CrossRef]

71. Alves-Silva, J.M.; Piras, A.; Porcedda, S.; Falconieri, D.; Maxia, A.; Gonçalves, M.J.; Cruz, M.T.; Salgueiro, L. Chemical characterization and bioactivity of the essential oil from Santolina insularis, a Sardinian endemism. Nat. Prod. Res. 2020, 1-5. [CrossRef] 
72. Radulović, N.S.; Randjelović, P.J.; Stojanović, N.M.; Blagojević, P.D.; Stojanović-Radić, Z.Z.; Ilić, I.R.; Djordjević, V.B. Toxic essential oils. Part II: Chemical, toxicological, pharmacological and microbiological profiles of Artemisia annua L. volatiles. Food Chem. Toxicol. 2013, 58, 37-49. [CrossRef]

73. Juliano, C.; Marchetti, M.; Pisu, M.L.; Usai, M. In vitro antimicrobial activity of essential oils from Sardinian flora against Cutibacterium (Formerly propionibacterium) acnes and its enhancement by chitosan. Sci. Pharm. 2018, 86, 40. [CrossRef]

74. Castangia, I.; Manca, M.L.; Caddeo, C.; Maxia, A.; Murgia, S.; Pons, R.; Demurtas, D.; Pando, D.; Falconieri, D.; Peris, J.E.; et al. Faceted phospholipid vesicles tailored for the delivery of Santolina insularis essential oil to the skin. Colloids Surf. B Biointerfaces 2015, 132, 185-193. [CrossRef]

75. Pintore, G.; Chessa, M.; Manconi, P.; Zanetti, S.; Deriu, A.; Tirillini, B. Chemical composition and antimicrobial activities of essential oil of Stachys glutinosa from Sardinia. Nat. Prod. Commun. 2006, 1, 1133-1136.

76. Maxia, A.; Sanna, C.; Piras, A.; Porcedda, S.; Falconieri, D.; Gonçalves, M.J.M.J.; Cavaleiro, C.; Salgueiro, L. Chemical composition and biological activity of Tanacetum audibertii (Req.) DC. (Asteraceae), an endemic species of Sardinia Island, Italy. Ind. Crops Prod. 2015, 65, 472-476. [CrossRef]

77. Zuzarte, M.; Gonçalves, M.J.; Cavaleiro, C.; Cruz, M.T.; Benzarti, A.; Marongiu, B.; Maxia, A.; Piras, A.; Salgueiro, L. Antifungal and anti-inflammatory potential of Lavandula stoechas and Thymus herba-barona essential oils. Ind. Crops Prod. 2013, 44, 97-103. [CrossRef]

78. Cosentino, S.; Tuberoso, C.I.G.; Pisano, B.; Satta, M.; Mascia, V.; Arzedi, E.; Palmas, F. In-vitro antimicrobial activity and chemical composition of Sardinian Thymus essential oils. Lett. Appl. Microbiol. 1999, 29, 130-135. [CrossRef]

79. Juliano, C.; Mattana, A.; Usai, M. Composition and in vitro antimicrobial activity of the essential oil of Thymus herba-barona Loisel growing wild in Sardinia. J. Essent. Oil Res. 2000, 12, 516-522. [CrossRef]

80. Mukhtar, M.; Arshad, M.; Ahmad, M.; Pomerantz, R.J.; Wigdahl, B.; Parveen, Z. Antiviral potentials of medicinal plants. Virus Res. 2008, 131, 111-120. [CrossRef]

81. Nothias, L.F.; Boutet-Mercey, S.; Cachet, X.; De La Torre, E.; Laboureur, L.; Gallard, J.F.; Retailleau, P.; Brunelle, A.; Dorrestein, P.C.; Costa, J.; et al. Environmentally Friendly Procedure Based on Supercritical Fluid Chromatography and Tandem Mass Spectrometry Molecular Networking for the Discovery of Potent Antiviral Compounds from Euphorbia semiperfoliata. J. Nat. Prod. 2017, 80, 2620-2629. [CrossRef]

82. Nothias-Scaglia, L.-F.; Retailleau, P.; Paolini, J.; Pannecouque, C.; Neyts, J.; Dumontet, V.; Roussi, F.; Leyssen, P.; Costa, J.; Litaudon, M. Jatrophane diterpenes as inhibitors of chikungunya virus replication: Structure-activity relationship and discovery of a potent lead. J. Nat. Prod. 2014, 77, 1505-1512. [CrossRef]

83. Appendino, G.; Ottino, M.; Marquez, N.; Bianchi, F.; Giana, A.; Ballero, M.; Sterner, O.; Fiebich, B.L.; Munoz, E. Arzanol, an anti-inflammatory and anti-HIV-1 phloroglucinol $\alpha$-pyrone from Helichrysum italicum ssp. microphyllum. J. Nat. Prod. 2007, 70, 608-612. [CrossRef]

84. Esposito, F.; Sanna, C.; Del Vecchio, C.; Cannas, V.; Venditti, A.; Corona, A.; Bianco, A.; Serrilli, A.M.; Guarcini, L.; Parolin, C.; et al. Hypericum hircinum L. Components as new single-molecule inhibitors of both HIV-1 reverse transcriptase-associated DNA polymerase and ribonuclease H activities. Pathog. Dis. 2013, 68, 116-124. [CrossRef]

85. Fujioka, T.; Kashiwada, Y.; Kilkuskie, R.E.; Cosentino, L.M.; Bailas, L.M.; Jiang, J.B.; Janzen, W.P.; Chen, I.S.; Lee, K.H. Anti-aids agents, 11 betulinic acid and platanic acid as anti-HIV principles from syzigium claviflorum, and the anti-HIV activity of structurally related triterpenoids. J. Nat. Prod. 1994, 57, $243-247$. [CrossRef] [PubMed]

86. Sanna, C.; Scognamiglio, M.; Fiorentino, A.; Corona, A.; Graziani, V.; Caredda, A.; Cortis, P.; Montisci, M.; Ceresola, E.R.; Canducci, F.; et al. Prenylated phloroglucinols from Hypericum scruglii, an endemic species of Sardinia (Italy), as new dual HIV-1 inhibitors effective on HIV-1 replication. PLoS ONE 2018, 12, e0195168. [CrossRef] [PubMed]

87. Bridi, H.; De Carvalho Meirelle, G.; von Poser, G.L. Structural diversity and biological activities of phloroglucinol derivatives from Hypericum species. Phytochemistry 2018, 155, 203-232. [CrossRef]

88. Sanna, C.; Rigano, D.; Corona, A.; Piano, D.; Formisano, C.; Farci, D.; Franzini, G.; Ballero, M.; Chianese, G.; Tramontano, E.; et al. Dual HIV-1 reverse transcriptase and integrase inhibitors from Limonium morisianum Arrigoni, an endemic species of Sardinia (Italy). Nat. Prod. Res. 2019, 33, 1798-1803. [CrossRef] [PubMed]

89. Karas, D.; Ulrichová, J.; Valentová, K. Galloylation of polyphenols alters their biological activity. Food Chem. Toxicol. 2017, 105, 223-240. [CrossRef] 
90. Daino, G.L.; Frau, A.; Sanna, C.; Rigano, D.; Distinto, S.; Madau, V.; Esposito, F.; Fanunza, E.; Bianco, G.; Taglialatela-Scafati, O.; et al. Identification of Myricetin as an Ebola Virus VP35-Double-Stranded RNA Interaction Inhibitor through a Novel Fluorescence-Based Assay. Biochemistry 2018, 57, 6367-6378. [CrossRef]

91. Cagno, V.; Sgorbini, B.; Sanna, C.; Cagliero, C.; Ballero, M.; Civra, A.; Donalisio, M.; Bicchi, C.; Lembo, D.; Rubiolo, P. In vitro anti-herpes simplex virus-2 activity of Salvia desoleana Atzei \& V. Picci essential oil. PLoS ONE 2017, 12, e0172322. [CrossRef]

92. De Logu, A.; Loy, G.; Pellerano, M.L.; Bonsignore, L.; Schivo, M.L. Inactivation of HSV-1 and HSV-2 and prevention of cell-to-cell virus spread by Santolina insularis essential oil. Antivir. Res. 2000, 48, 177-185. [CrossRef]

93. Valenti, D.; De Logu, A.; Loy, G.; Sinico, C.; Bonsignore, L.; Cottiglia, F.; Garau, D.; Fadda, A. Liposome-incorporated Santolina insularis essential oil: Preparation, characterization and in vitro antiviral activity. J. Liposome Res. 2001, 11, 73-90. [CrossRef] [PubMed]

94. World Health Organization. WHO Report on Cancer: Setting Priorities Investing Wisely and Providing Care for All; World Health Organization: Geneva, Switzerland, 2020; ISBN 9789240001299.

95. Shin, S.-A.; Moon, S.Y.; Kim, W.-Y.; Paek, S.-M.; Park, H.H.; Lee, C.S. Structure-Based Classification and Anti-Cancer Effects of Plant Metabolites. Int. J. Mol. Sci. 2018, 19, 2651. [CrossRef]

96. Agarwal, G.; Carcache, P.J.B.; Addo, E.M.; Kinghorn, A.D. Current status and contemporary approaches to the discovery of antitumor agents from higher plants. Biotechnol. Adv. 2020, 38, 107337. [CrossRef] [PubMed]

97. Ornano, L.; Venditti, A.; Sanna, C.; Ballero, M.; Maggi, F.; Lupidi, G.; Bramucci, M.; Quassinti, L.; Bianco, A. Chemical composition and biological activity of the essential oil from Helichrysum microphyllum cambess. ssp. tyrrhenicum Bacch., Brullo e Giusso growing in La Maddalena archipelago, Sardinia. J. Oleo Sci. 2015, 64, 19-26. [CrossRef]

98. Ornano, L.; Venditti, A.; Ballero, M.; Sanna, C.; Donno, Y.; Quassinti, L.; Bramucci, M.; Vitali, L.A.; Petrelli, D.; Tirillini, B.; et al. Essential oil composition and biological activity from Artemisia caerulescens subsp. densiflora (Viv.) Gamisans ex Kerguélen \& Lambinon (Asteraceae), an endemic species in the habitat of La Maddalena Archipelago. Nat. Prod. Res. 2016, 30, 1802-1809. [CrossRef]

99. Calcabrini, A.; Stringaro, A.; Toccacieli, L.; Meschini, S.; Marra, M.; Colone, M.; Salvatore, G.; Mondello, F.; Arancia, G.; Molinari, A. Terpinen-4-ol, the Main Component of Melaleuca alternifolia (Tea Tree) Oil Inhibits the in Vitro Growth of Human Melanoma Cells. J. Investig. Dermatol. 2004, 122, 349-360. [CrossRef] [PubMed]

100. Greay, S.J.; Ireland, D.J.; Kissick, H.T.; Levy, A.; Beilharz, M.W.; Riley, T.V.; Carson, C.F. Induction of necrosis and cell cycle arrest in murine cancer cell lines by Melaleuca alternifolia (tea tree) oil and terpinen-4-ol. Cancer Chemother. Pharmacol. 2010, 65, 877-888. [CrossRef] [PubMed]

101. Rosa, A.; Atzeri, A.; Nieddu, M.; Appendino, G. New insights into the antioxidant activity and cytotoxicity of arzanol and effect of methylation on its biological properties. Chem. Phys. Lipids 2017, 205, 55-64. [CrossRef]

102. Cottiglia, F.; Casu, L.; Bonsignore, L.; Casu, M.; Floris, C.; Leonti, M.; Gertsch, J.; Heilmann, J. New cytotoxic prenylated isoflavonoids from Bituminaria morisiana. Planta Med. 2005, 71, 254-260. [CrossRef]

103. Leonti, M.; Casu, L.; Gertsch, J.; Bonsignore, L.; Floris, C.; Casu, M.; Cottiglia, F. A pterocarpan from the seeds of Bituminaria morisiana. J. Nat. Med. 2010, 64, 354-357. [CrossRef]

104. Miglietta, A.; Gabriel, L.; Appendino, G.; Bocca, C. Biological properties of jatrophane polyesters, new microtubule-interacting agents. Cancer Chemother. Pharmacol. 2003, 51, 67-74. [CrossRef]

105. Poli, F.; Appendino, G.; Sacchetti, G.; Ballero, M.; Maggiano, N.; Ranelletti, F.O. Antiproliferative effects of daucane esters from Ferula communis and F. arrigonii on human colon cancer cell lines. Phyther. Res. 2005, 19, 152-157. [CrossRef]

106. Appendino, G.; Jakupovic, J.; Alloatti, S.; Ballero, M. Daucane esters from Ferula arrigonii. Phytochemistry 1997, 45, 1639-1643. [CrossRef]

107. Ranelletti, F.O.; Ricci, R.; Larocca, L.M.; Maggiano, N.; Capelli, A.; Scambia, G.; Benedetti-Panici, P.; Mancuso, S.; Rumi, C.; Piantelli, M. Growth-inhibitory effect of quercetin and presence of type-II estrogen-binding sites in human colon-cancer cell lines and primary colorectal tumors. Int. J. Cancer 1992, 50, 486-492. [CrossRef] [PubMed]

108. Bush, N.G.; Evans-roberts, K.; Maxwell, A. Macromolecules DNA Topoisomerases. EcoSal Plus 2015, 6. [CrossRef]

109. Casu, L.; Bonsignore, L.; Pinna, M.; Casu, M.; Floris, C.; Gertsch, J.; Cottiglia, F. Cytotoxic diacetylenic spiroketal enol ethers from Plagius flosculosus. J. Nat. Prod. 2006, 69, 295-298. [CrossRef] [PubMed] 
110. Bonesi, M.; Brindisi, M.; Armentano, B.; Curcio, R.; Sicari, V.; Loizzo, M.R.; Cappello, M.S.; Bedini, G.; Peruzzi, L.; Tundis, R. Exploring the anti-proliferative, pro-apoptotic, and antioxidant properties of Santolina corsica Jord. \& Fourr. (Asteraceae). Biomed. Pharmacother. 2018, 107, 967-978. [CrossRef]

111. Zhao, Y.; Chen, R.; Wang, Y.; Yang, Y. $\alpha$-Pinene Inhibits Human Prostate Cancer Growth in a Mouse Xenograft Model. Chemotherapy 2018, 63, 1-7. [CrossRef]

112. Manuele, M.G.; Arcos, M.L.B.; Davicino, R.; Ferraro, G.; Cremaschi, G.; Anesini, C. Mechanism of the antiproliferative action of limonene on a lymphoma cell line: Participation of nitric oxide. antiproliferative action of limonene on a lymphoma cell line. Phytother. Res. 2009, 23, 1011-1017. [CrossRef]

113. García, E.R.; Gutierrez, E.A.; de Melo, F.C.S.A.; Novaes, R.D.; Gonçalves, R.V. Flavonoids Effects on Hepatocellular Carcinoma in Murine Models: A Systematic Review. Evid. Based Complement. Alternat. Med. 2018, 2018, 6328970. [CrossRef]

114. Wu, Q.; Needs, P.W.; Lu, Y.; Kroon, P.A.; Ren, D.; Yang, X. Different antitumor effects of quercetin, quercetin-3'-sulfate and quercetin-3-glucuronide in human breast cancer MCF-7 cells. Food Funct. 2018, 9 , 1736-1746. [CrossRef]

115. Kerr, J.F.R.; Wyllie, A.H.; Currie, A.R. Apoptosis: A basic biological phenomenon with wide-ranging implications in tissue kinetics. Br. J. Cancer 1972, 26, 239-257. [CrossRef]

116. Appendino, G.; Aviello, G.; Ballero, M.; Borrelli, F.; Fattorusso, E.; Petrucci, F.; Santelia, F.U.; Taglialatela-Scafati, O. Cytotoxic germacrane sesquiterpenes from the aerial parts of Santolina insularis. J. Nat. Prod. 2005, 68, 853-857. [CrossRef] [PubMed]

117. Kupchan, S.M.; Eakin, M.A.; Thomas, A.M. Tumor Inhibitors. 69. Structure-Cytotoxicity Relationships among the Sesquiterpene Lactones. J. Med. Chem. 1971, 14, 1147-1152. [CrossRef] [PubMed]

118. Leporini, L.; Menghini, L.; Foddai, M.; Petretto, G.L.; Chessa, M.; Tirillini, B.; Pintore, G. Antioxidant and antiproliferative activity of Stachys glutinosa L. ethanol extract. Nat. Prod. Res. 2015, 29, 899-907. [CrossRef] [PubMed]

119. Cappadone, C.; Mandrone, M.; Chiocchio, I.; Sanna, C.; Malucelli, E.; Bassi, V.; Picone, G.; Poli, F. Antitumor potential and phytochemical profile of plants from Sardinia (Italy), a hotspot for biodiversity in the mediterranean basin. Plants 2020, 9, 26. [CrossRef] [PubMed]

120. Hientz, K.; Mohr, A.; Bhakta-Guha, D.; Efferth, T. The role of p53 in cancer drug resistance and targeted chemotherapy. Oncotarget 2017, 8. [CrossRef] [PubMed]

121. Shalini, S.; Dorstyn, L.; Dawar, S.; Kumar, S. Old, new and emerging functions of caspases. Cell Death Differ. 2015, 22, 526-539. [CrossRef]

122. Folkman, J. Fighting cancer by attacking its blood supply. Sci. Am. 1996, 275, 150-154. [CrossRef]

123. Bhattacharya, S. Natural antimutagens: A review. Res. J. Med. Plant. 2011, 5, 116-126. [CrossRef]

124. Verschaeve, L. Genotoxicity and antigenotoxicity studies of traditional medicinal plants: How informative and accurate are the results? Nat. Prod. Commun. 2015, 10, 1489-1493. [CrossRef]

125. Scarpato, R.; Paganucci, L.; Bertoli, A.; Fiore, L.; Pistelli, L.; Federico, G. Licoflavone C attenuates the genotoxicity of cancer drugs in human peripheral lymphocytes. Phyther. Res. 2008, 22, 1650-1654. [CrossRef]

126. Noel, S.; Kasinathan, M.; Rath, S.K. Evaluation of apigenin using in vitro cytochalasin blocked micronucleus assay. Toxicol. Vitr. 2006, 20, 1168-1172. [CrossRef]

127. Kim, G.H.; Kim, J.E.; Rhie, S.J.; Yoon, S. The Role of Oxidative Stress in Neurodegenerative Diseases. Exp. Neurobiol. 2015, 24, 325-340. [CrossRef] [PubMed]

128. Neha, K.; Haider, M.R.; Pathak, A.; Yar, M.S. Medicinal prospects of antioxidants: A review. Eur. J. Med. Chem. 2019, 178, 687-704. [CrossRef] [PubMed]

129. Birch-Machin, M.A.; Bowman, A. Oxidative stress and ageing. Br. J. Dermatol. 2016, 175, 26-29. [CrossRef] [PubMed]

130. Rosa, A.; Deiana, M.; Corona, G.; Atzeri, A.; Incani, A.; Appendino, G.; Dessì, M.A. Antioxidant properties of extracts and compounds from Psoralea morisiana. Eur. J. Lipid Sci. Technol. 2005, 107, 521-529. [CrossRef]

131. Bruni, R.; Muzzoli, M.; Ballero, M.; Loi, M.C.; Fantin, G.; Poli, F.; Sacchetti, G. Tocopherols, fatty acids and sterols in seeds of four Sardinian wild Euphorbia species. Fitoterapia 2004, 75, 50-61. [CrossRef]

132. Serrilli, A.M.; Graziosi, V.; Ballero, M.; Foddis, C.; Serafini, M.; Poli, F.; Scartezzini, P.; Bianco, A. Endemic Sardinian plants: The case of Genista cadasonensis Valsecchi. Nat. Prod. Res. 2010, 24, 942-947. [CrossRef] 
133. Bauer, J.; Koeberle, A.; Dehm, F.; Pollastro, F.; Appendino, G.; Northoff, H.; Rossi, A.; Sautebin, L.; Werz, O. Arzanol, a prenylated heterodimeric phloroglucinyl pyrone, inhibits eicosanoid biosynthesis and exhibits anti-inflammatory efficacy in vivo. Biochem. Pharmacol. 2011, 81, 259-268. [CrossRef]

134. Rosa, A.; Deiana, M.; Atzeri, A.; Corona, G.; Incani, A.; Melis, M.P.; Appendino, G.; Dessì, M.A. Evaluation of the antioxidant and cytotoxic activity of arzanol, a prenylated $\alpha$-pyrone-phloroglucinol etherodimer from Helichrysum italicum subsp. microphyllum. Chem. Biol. Interact. 2007, 165, 117-126. [CrossRef]

135. Rosa, A.; Pollastro, F.; Atzeri, A.; Appendino, G.; Melis, M.P.; Deiana, M.; Incani, A.; Loru, D.; Dess, M.A. Protective role of arzanol against lipid peroxidation in biological systems. Chem. Phys. Lipids 2011, 164, 24-32. [CrossRef]

136. Mandrone, M.; Lorenzi, B.; Venditti, A.; Guarcini, L.; Bianco, A.; Sanna, C.; Ballero, M.; Poli, F.; Antognoni, F. Antioxidant and anti-collagenase activity of Hypericum hircinum L. Ind. Crops Prod. 2015, 76, 402-408. [CrossRef]

137. Mandrone, M.; Scognamiglio, M.; Fiorentino, A.; Sanna, C.; Cornioli, L.; Antognoni, F.; Bonvicini, F.; Poli, F. Phytochemical profile and $\alpha$-glucosidase inhibitory activity of Sardinian Hypericum scruglii and Hypericum hircinum. Fitoterapia 2017, 120, 184-193. [CrossRef] [PubMed]

138. Posadino, A.M.; Porcu, M.C.; Marongiu, B.; Cossu, A.; Piras, A.; Porcedda, S.; Falconieri, D.; Cappuccinelli, R.; Biosa, G.; Pintus, G.; et al. Antioxidant activity of supercritical carbon dioxide extracts of Salvia desoleana on two human endothelial cell models. Food Res. Int. 2012, 46, 354-359. [CrossRef]

139. Moulines, J.; Lamidey, A.M.; Desvergnes-Breuil, V. A practical synthesis of ambrox ${ }^{\circledR}$ from sclareol using no metallic oxidant. Synth. Commun. 2001, 31, 749-758. [CrossRef]

140. Foddai, M.; Maldini, M.; Addis, R.; Petretto, G.L.; Chessa, M.; Pintore, G. Profiling of the bioactive compounds in flowers, leaves and roots of Vinca sardoa. Nat. Prod. Commun. 2017, 12, 933-936. [CrossRef]

141. Rice-Evans, C.A.; Miller, N.J.; Paganga, G. Structure-antioxidant activity relationships of flavonoids and phenolic acids. Free Radic. Biol. Med. 1996, 20, 933-956. [CrossRef]

142. Kono, Y.; Kashine, S.; Yoneyama, T.; Sakamoto, Y.; Matsui, Y.; Shibata, H. Iron chelation by chlorogenic acid as a natural antioxidant. Biosci. Biotechnol. Biochem. 1998, 62, 22-27. [CrossRef]

143. Marinova, E.M.; Toneva, A.; Yanishlieva, N. Comparison of the antioxidative properties of caffeic and chlorogenic acids. Food Chem. 2009, 114, 1498-1502. [CrossRef]

144. Hou, C.; Chen, L.; Yang, L.; Ji, X. An insight into anti-inflammatory effects of natural polysaccharides. Int. J. Biol. Macromol. 2020, 153, 248-255. [CrossRef]

145. Azab, A.; Nassar, A.; Azab, A.N. Anti-inflammatory activity of natural products. Molecules 2016, $21,1321$. [CrossRef]

146. Kishore, N.; Kumar, P.; Shanker, K.; Verma, A.K. Human disorders associated with inflammation and the evolving role of natural products to overcome. Eur. J. Med. Chem. 2019, 179, 272-309. [CrossRef] [PubMed]

147. Hume, D.; Fairlie, D. Therapeutic Targets in Inflammatory Disease. Curr. Med. Chem. 2005, 12, $2925-2929$. [CrossRef] [PubMed]

148. Avonto, C.; Rua, D.; Lasonkar, P.B.; Chittiboyina, A.G.; Khan, I.A. Identification of a compound isolated from German chamomile (Matricaria chamomilla) with dermal sensitization potential. Toxicol. Appl. Pharmacol. 2017, 318, 16-22. [CrossRef]

149. Calzado, M.A.; Lüdi, K.S.; Fiebich, B.; Ben-Neriah, Y.; Bacher, S.; Munoz, E.; Ballero, M.; Prosperini, S.; Appendino, G.; Schmitz, M.L. Inhibition of NF- $\kappa$ B activation and expression of inflammatory mediators by polyacetylene spiroketals from Plagius flosculosus. Biochim. Biophys. Acta Gene Struct. Expr. 2005, 1729, 88-93. [CrossRef] [PubMed]

150. Peana, A.; Satta, M. A preliminary research on essential oil of Salvia sclarea L. and Salvia desoleana Atzei \& Picci. Pharmacol. Res. 1993, 27, 25-26.

151. Foddai, M.; Marchetti, M.; Ruggero, A.; Juliano, C.; Usai, M. Evaluation of chemical composition and anti-inflammatory, antioxidant, antibacterial activity of essential oil of Sardinian Santolina corsica Jord. \& Fourr. Saudi J. Biol. Sci. 2019, 26, 930-937. [CrossRef]

152. Cottiglia, F.; Casu, L.; Bonsignore, L.; Casu, M.; Floris, C.; Sosa, S.; Altinier, G.; Della Loggia, R. Topical anti-inflammatory activity of flavonoids and a new xanthone from Santolina insularis. Z. Fur Naturforsch. Sect. C J. Biosci. 2005, 60, 63-66. [CrossRef]

153. Boeing, T.; de Souza, P.; Speca, S.; Somensi, L.B.; Mariano, L.N.B.; Cury, B.J.; Ferreira dos Anjos, M.; Quintão, N.L.M.; Dubuqoy, L.; Desreumax, P.; et al. Luteolin prevents irinotecan-induced intestinal mucositis 
in mice through antioxidant and anti-inflammatory properties. Br. J. Pharmacol. 2020, 177, 2393-2408. [CrossRef]

154. Farage, M.A.; Miller, K.W.; Elsner, P.; Maibach, H.I. Intrinsic and extrinsic factors in skin ageing: A review. Int. J. Cosmet. Sci. 2008, 30, 87-95. [CrossRef]

155. Harvell, J.D.; Maibach, H.I. Percutaneous absorption and inflammation in aged skin: A review. J.Am. Acad. Dermatol. 1994, 31, 1015-1021. [CrossRef]

156. Thring, T.S.A.; Hili, P.; Naughton, D.P. Anti-collagenase, anti-elastase and anti-oxidant activities of extracts from 21 plants. BMC Complement. Altern. Med. 2009, 9, 27. [CrossRef] [PubMed]

157. Pillaiyar, T.; Manickam, M.; Namasivayam, V. Skin whitening agents: Medicinal chemistry perspective of tyrosinase inhibitors. J. Enzym. Inhib. Med. Chem. 2017, 32, 403-425. [CrossRef] [PubMed]

158. Mukherjee, P.K.; Maity, N.; Nema, N.K.; Sarkar, B.K. Bioactive compounds from natural resources against skin aging. Phytomedicine 2011, 19, 64-73. [CrossRef]

159. Chiocchio, I.; Mandrone, M.; Sanna, C.; Maxia, A.; Tacchini, M.; Poli, F. Screening of a hundred plant extracts as tyrosinase and elastase inhibitors, two enzymatic targets of cosmetic interest. Ind. Crops Prod. 2018, 122, 498-505. [CrossRef]

160. Liu, T.; Li, N.; Yan, Y.; Liu, Y.; Xiong, K.; Liu, Y.; Xia, Q.; Zhang, H.; Liu, Z. Recent advances in the anti-aging effects of phytoestrogens on collagen, water content, and oxidative stress. Phyther. Res. 2020, 34, 435-447. [CrossRef]

161. Ososki, A.L.; Kennelly, E.J. Phytoestrogens: A review of the present state of research. Phyther. Res. 2003, 17, 845-869. [CrossRef]

162. Patisaul, H.B.; Jefferson, W. The pros and cons of phytoestrogens. Front. Neuroendocrinol. 2010, 31, 400-419. [CrossRef]

163. Viggiani, M.T.; Polimeno, L.; Di Leo, A.; Barone, M. Phytoestrogens: Dietary intake, bioavailability, and protective mechanisms against colorectal neoproliferative lesions. Nutrients 2019, 11, 1709. [CrossRef]

164. Garritano, S.; Pinto, B.; Giachi, I.; Pistelli, L.; Reali, D. Assessment of estrogenic activity of flavonoids from Mediterranean plants using an in vitro short-term test. Phytomedicine 2005, 12, 143-147. [CrossRef]

165. Pinto, B.; Bertoli, A.; Noccioli, C.; Garritano, S.; Reali, D.; Pistelli, L. Estradiol-antagonistic activity of phenolic compounds from leguminous plants. Phytother. Res. 2008, 22, 362-366. [CrossRef]

166. Zierau, O.; Gester, S.; Schwab, P.; Metz, P.; Kolba, S.; Wulf, M.; Vollmer, G. Estrogenic activity of the phytoestrogens naringenin, 6-(1,1-dimethylallyl) naringenin and 8-prenylnaringenin. Planta Med. 2002, 68, 449-451. [CrossRef] [PubMed]

167. Wild, S.; Roglic, G.; Green, A.; Sicree, R.; King, H. Global Prevalence of Diabetes: Estimates for the year 2000 and projections for 2030. Diabetes Care 2004, 27, 1047-1053. [CrossRef] [PubMed]

168. Dowarah, J.; Singh, V.P. Anti-diabetic drugs recent approaches and advancements. Bioorg. Med. Chem. 2020, 28, 115263. [CrossRef] [PubMed]

169. Bashary, R.; Vyas, M.; Nayak, S.K.; Suttee, A.; Verma, S.; Narang, R.; Khatik, G.L. An Insight of Alpha-amylase Inhibitors as a Valuable Tool in the Management of Type 2 Diabetes Mellitus. Curr. Diabetes Rev. 2019, 16, 117-136. [CrossRef] [PubMed]

170. Hedrington, M.S.; Davis, S.N. Considerations when using alpha-glucosidase inhibitors in the treatment of type 2 diabetes. Expert Opin. Pharmacother. 2019, 20, 2229-2235. [CrossRef] [PubMed]

171. Agatonovic-Kustrin, S.; Kustrin, E.; Gegechkori, V.; Morton, D.W. Bioassay-guided identification of $\alpha$-amylase inhibitors in herbal extracts. J. Chromatogr. A 2020, 1620, 460970. [CrossRef]

172. Beidokhti, M.N.; Eid, H.M.; Villavicencio, M.L.S.; Jäger, A.K.; Lobbens, E.S.; Rasoanaivo, P.R.; McNair, L.M.; Haddad, P.S.; Staerk, D. Evaluation of the antidiabetic potential of Psidium guajava L. (Myrtaceae) using assays for $\alpha$-glucosidase, $\alpha$-amylase, muscle glucose uptake, liver glucose production and triglyceride accumulation in adipocytes. J. Ethnopharmacol. 2020, 112877. [CrossRef]

173. Sun, L.; Warren, F.J.; Gidley, M.J. Natural products for glycaemic control: Polyphenols as inhibitors of alpha-amylase. Trends Food Sci. Technol. 2019, 91, 262-273. [CrossRef]

174. Foddai, M.; Kasabri, V.; Petretto, G.L.; Azara, E.; Sias, A.; Afifi, F.U.; Delogu, G.; Chessa, M.; Pintore, G. In vitro inhibitory effects of Limonium contortirameum and L. virgatum extracts from Sardinia on $\alpha$-amylase, $\alpha$-glucosidase and pancreatic lipase. Nat. Prod. Commun. 2014, 9, 181-184. [CrossRef] 
175. Hussain, S.A.; Ahmed, Z.A.; Mahwi, T.O.; Aziz, T.A. Effect of quercetin on postprandial glucose excursion after mono- and disaccharides challenge in normal and diabetic rats. J. Diabetes Mellit. 2012, 02, 82-87. [CrossRef]

176. Zheng, C.-D.; Duan, Y.-Q.; Gao, J.-M.; Ruan, Z.-G. Screening for anti-lipase properties of 37 traditional Chinese medicinal herbs. J. Chin. Med. Assoc. 2010, 73, 319-324. [CrossRef]

177. Oi, Y.; Hou, I.C.; Fujita, H.; Yazawa, K. Antiobesity effects of Chinese black tea (Pu-erh tea) extract and gallic acid. Phyther. Res. 2012, 26, 475-481. [CrossRef] [PubMed]

178. Shah, S.; Mohan, M.; Kasture, S.; Ballero, M.; Maxia, A.; Sanna, C. Protective effect of Hypericum hircinum on doxorubicin-induced cardiotoxicity in rats. Nat. Prod. Res. 2013, 27. [CrossRef] [PubMed]

179. Horie, T.; Ono, K.; Nishi, H.; Nagao, K.; Kinoshita, M.; Watanabe, S.; Kuwabara, Y.; Nakashima, Y.; Takanabe-Mori, R.; Nishi, E.; et al. Acute doxorubicin cardiotoxicity is associated with miR-146a-induced inhibition of the neuregulin-ErbB pathway. Cardiovasc. Res. 2010, 87, 656-664. [CrossRef] [PubMed]

180. Hahn, V.S.; Lenihan, D.J.; Ky, B. Cancer therapy-induced cardiotoxicity: Basic mechanisms and potential cardioprotective therapies. J. Am. Heart Assoc. 2014, 3, e000665. [CrossRef]

181. Carta, M.G.; Manconi, M.; Bacchetta, G.; Orrù, G.; Deidda, M.C.; Musu, M.; Finco, G. Hypericum scruglii Bacchetta, Brullo \& Salmeri, is it a possible natural resource against Fibromyalgia? Int. J. Phytomed. 2020, 12, 2.

182. Chimenti, F.; Cottiglia, F.; Bonsignore, L.; Casu, L.; Casu, M.; Floris, C.; Secci, D.; Bolasco, A.; Chimenti, P.; Granese, A.; et al. Quercetin as the active principle of Hypericum hircinum exerts a selective inhibitory activity against MAO-A: Extraction, biological analysis, and computational study. J. Nat. Prod. 2006, 69, 945-949. [CrossRef]

183. Wouters, J. Structural aspects of monoamine oxidase and its reversible inhibition. Curr. Med. Chem. 1998, 5, 137-162.

184. Ceschel, G.C.; Maffei, P.; Moretti, M.D.L.; Demontis, S.; Peana, A.T. In vitro permeation through porcine buccal mucosa of Salvia desoleana Atzei and Picci essential oil from topical formulations. Int. J. Pharm. 2000, 195, 171-177. [CrossRef]

185. Iannello, C.; Pigni, N.B.; Antognoni, F.; Poli, F.; Maxia, A.; De Andrade, J.P.; Bastida, J. A potent acetylcholinesterase inhibitor from Pancratium illyricum L. Fitoterapia 2014, 92, 163-167. [CrossRef]

186. Ruiu, S.; Anzani, N.; Orrü, A.; Floris, C.; Caboni, P.; Alcaro, S.; Maccioni, E.; Distinto, S.; Cottiglia, F. Methoxyflavones from Stachys glutinosa with binding affinity to opioid receptors: In silico, in vitro, and in vivo studies. J. Nat. Prod. 2015, 78, 69-76. [CrossRef] [PubMed]

187. Nutt, D.J. The role of the opioid system in alcohol dependence. J. Psychopharmacol. 2014, 28, 8-22. [CrossRef] [PubMed]

188. Łabuzek, K.; Beil, S.; Beil-Gawełczyk, J.; Gabryel, B.; Franik, G.; Okopień, B. The latest achievements in the pharmacotherapy of gambling disorder. Pharmacol. Rep. 2014, 66, 811-820. [CrossRef]

189. Gnavi, G.; Bertea, C.M.; Usai, M.; Maffei, M.E. Comparative characterization of Santolina insularis chemotypes by essential oil composition, 5S-rRNA-NTS sequencing and EcoRV RFLP-PCR. Phytochemistry 2010, 71, 930-936. [CrossRef]

190. Corticchiato, M.; Tomi, F.; François Bernardini, A.; Casanova, J. Composition and infraspecific variability of essential oil from Thymus herba barona Lois. Biochem. Syst. Ecol. 1998, 26, 915-932. [CrossRef]

191. Biondi, E.; Valentini, G.; Bellomaria, B. Essential Oil of Some Halophyle and Subhalophyle Taxa Artemisia L. from the Central European Mediterranean. J. Essent. Oil Res. 2000, 12, 365-371. [CrossRef]

192. Usai, M.; Foddai, M.; Bernardini, A.F.; Muselli, A.; Costa, J.; Marchetti, M. Chemical composition and variation of the essential oil of wild sardinian Helichrysum italicum G. Don subsp. microphyllum (Willd.) Nym. from vegetative period to post-blooming. J. Essent. Oil Res. 2010, 22, 373-380. [CrossRef]

193. Melito, S.; Petretto, G.L.; Podani, J.; Foddai, M.; Maldini, M.; Chessa, M.; Pintore, G. Altitude and climate influence Helichrysum italicum subsp. microphyllum essential oils composition. Ind. Crops Prod. 2016, 80, 242-250. [CrossRef]

194. Scott, D. Determining the type of relationship between plants and environmental factors. Proc. N. Z. Ecol. Soc. 1969, 16, 29-31.

195. Marongiu, B.; Piras, A.; Porcedda, S.; Tuveri, E.; Maxia, A. Isolation of Seseli bocconi Guss, subsp. praecox Gamisans (Apiaceae) volatile oil by supercritical carbon dioxide extraction. Nat. Prod. Res. 2006, 20, 820-826. [CrossRef] [PubMed] 
196. Bertoli, A.; Loi, M.C.; Noccioli, C.; Maxia, L.; Moonen, A.C.; Pistelli, L. Volatile constituents as complementary tools to characterize seven sardinian Genista species. Biochem. Syst. Ecol. 2015, 62, 82-90. [CrossRef]

197. Appendino, G.; Belloro, E.; Tron, G.C.; Jakupovic, J.; Ballero, M. Diterpenoids from Euphorbia pithyusa subsp. cupanii. J. Nat. Prod. 1999, 62, 1399-1404. [CrossRef] [PubMed]

198. Appendino, G.; Jakupovic, S.; Tron, G.C.; Jakupovic, J.; Milon, V.; Ballero, M. Macrocyclic diterpenoids from Euphorbia semiperfoliata. J. Nat. Prod. 1998, 61, 749-756. [CrossRef] [PubMed]

199. Nothias-Scaglia, L.F.; Gallard, J.F.; Dumontet, V.; Roussi, F.; Costa, J.; Iorga, B.I.; Paolini, J.; Litaudon, M. Advanced Structural Determination of Diterpene Esters Using Molecular Modeling and NMR Spectroscopy. J. Nat. Prod. 2015, 78, 2423-2431. [CrossRef]

200. Venditti, A.; Lattanzi, C.; Ornano, L.; Maggi, F.; Sanna, C.; Ballero, M.; Alvino, A.; Serafini, M.; Bianco, A. A new glucosidic phthalide from Helichrysum microphyllum subsp. tyrrhenicum from la Maddalena Island (Sardinia, Italy). Nat. Prod. Res. 2016, 30, 789-795. [CrossRef]

201. Ornano, L.; Venditti, A.; Donno, Y.; Sanna, C.; Ballero, M.; Bianco, A. Phytochemical analysis of non-volatile fraction of Artemisia caerulescens subsp. densiflora (Viv.) (Asteraceae), an endemic species of la Maddalena Archipelago (Sardinia-Italy). Nat. Prod. Res. 2016, 30, 920-925. [CrossRef]

202. Pistelli, L.; Pardossi, S.; Flamini, G.; Bertoli, A.; Manunta, A. Three cycloastragenol glucosides from Astragalus verrucosus. Phytochemistry 1997, 45, 585-587. [CrossRef]

203. Pistelli, L.; Pardossi, S.; Bertoli, A.; Potenza, D. Cicloastragenol glycosides from Astragalus verrucosus. Phytochemistry 1998, 49, 2467-2471. [CrossRef]

204. Pistelli, L.; Giachi, I.; Lepori, E.; Bertoli, A. Further saponins and flavonoids from Astragalus verrucosus Moris. Pharm. Biol. 2003, 41, 568-572. [CrossRef]

205. Pistelli, L.; Noccioli, C.; Appendino, G.; Bianchi, F.; Sterner, O.; Ballero, M. Pterocarpans from Bituminaria morisiana and Bituminaria bituminosa. Phytochemistry 2003, 64, 595-598. [CrossRef]

206. Guil-Guerrero, J.L.; Gómez-Mercado, F.; Ramos-Bueno, R.P.; González-Fernández, M.J.; Urrestarazu, M.; Rincón-Cervera, M.Á. Sardinian Boraginaceae are new potential sources of gamma-linolenic acid. Food Chem. 2017, 218, 435-439. [CrossRef] [PubMed]

207. Flamini, G.; Bulleri, C.; Morelli, I.; Manunta, A. A new flavonoid glycoside from Centaurea horrida. J. Nat. Prod. 2000, 63, 662-663. [CrossRef] [PubMed]

208. Flamini, G.; Bulleri, C.; Morelli, I. Secondary constituents from Centaurea horrida and their evolutionary meaning. Biochem. Syst. Ecol. 2002, 30, 1051-1054. [CrossRef]

209. Serafini, M.; Foddai, S.; Ballero, M.; Guiso, M.; Bianco, A. The occurrence of iridoid glycosides in Cymbalaria spp. in Italy. Nat. Prod. Res. 2004, 18, 325-327. [CrossRef] [PubMed]

210. Appendino, G.; Spagliardi, P.; Ballero, M.; Seu, G. Macrocyclic diterpenoids from Euphorbia hyberna L. subsp. insularis and their reaction with oxyphilic reagents. Fitoterapia 2002, 73, 576-582. [CrossRef] [PubMed]

211. Petitto, V.; Serafini, M.; Ballero, M.; Foddai, S.; Stanzione, A.; Nicoletti, M. Iridoids from Euphrasia genargentea, a rare Sardinian endemism. Nat. Prod. Res. 2009, 23, 431-435. [CrossRef]

212. Casinovi, C.; Tomassini, L.; Nicoletti, M. A new guaianolide from Ferula arrigonii Bocchieri. Gazz. Chim. Ital. $1989,11,563$.

213. Serrilli, A.M.; Ramunno, A.; Amicucci, F.; Chicarella, V.; Santoni, S.; Ballero, M.; Serafini, M.; Bianco, A. Iridoidic pattern in endemic Sardinian plants: The case of Galium species. Nat. Prod. Res. 2008, 22, 618-622. [CrossRef]

214. Harborne, J.B. Chemosystematics of the Leguminosae. Flavonoid and isoflavonoid patterns in the tribe Genisteae. Phytochemistry 1969, 8, 1449-1456. [CrossRef]

215. Bernasconi, R.; Gill, S.; Steinegg, E. Versuch einer chemotaxonomisch-phylogenetischen Gliederung des Genus Genista. I. Quantitative Alkaloidverteilung in 26 Genista-Arten und Varietäten (8 Mitteilung über Leguminosenalkaloide). Pharm. Acta Helv. 1965, 40, 246-256.

216. Pistelli, L.; Giachi, I.; Potenza, D.; Morelli, I. A new isoflavone from Genista corsica. J. Nat. Prod. 2000, 63, 504-506. [CrossRef] [PubMed]

217. Pistelli, L.; Bertoli, A.; Giachi, I.; Manunta, A. Flavonoids from Genista ephedroides. J. Nat. Prod. 1998, 61, 1404-1406. [CrossRef] [PubMed]

218. Pistelli, L.; Bertoli, A.; Giachi, I.; Morelli, I.; Rubiolo, P.; Bicchi, C. Quinolizidine alkaloids from Genista ephedroides. Biochem. Syst. Ecol. 2001, 29, 137-141. [CrossRef] 
219. Giachi, I.; Manunta, A.; Morelli, I.; Pistelli, L. Flavonoids and isoflavonoids from Genista morisii. Biochem. Syst. Ecol. 2002, 30, 801-803. [CrossRef]

220. Noccioli, C.; Meini, L.; Loi, M.C.; Potenza, D.; Pistelli, L. A new alpinumisoflavone derivative from Genista pichisermolliana. Phytochem. Lett. 2011, 4, 342-344. [CrossRef]

221. Noccioli, C.; Luciardi, L.; Barsellini, S.; Favro, C.; Bertoli, A.; Bader, A.; Loi, M.C.; Pistelli, L. Flavonoids from two Italian genista species: Genista cilentina and Genista sulcitana. Chem. Nat. Compd. 2012, 48, 672-673. [CrossRef]

222. Giamperi, L.; Fraternale, D.; Cara, P.; Ricci, D.; Epifano, F.; Curini, M. Analysis of essential oils from wild and domesticated plants of Glechoma sardoa Bég. J. Essent. Oil Res. 2008, 20, 38-40. [CrossRef]

223. Satta, M.; Tuberoso, C.I.G.; Angioni, A.; Pirisi, F.M.; Cabras, P. Analysis of the essential oil of Helichrysum ifalicum G. Don ssp. microphyllum (Willd) Nym. J. Essent. Oil Res. 1999, 11, 711-715. [CrossRef]

224. Bianchini, A.; Tomi, P.; Bernardini, A.F.; Morelli, I.; Flamini, G.; Cioni, P.L.; Usaï, M.; Marchetti, M. A comparative study of volatile constituents of two Helichrysum italicum (Roth) Guss. Don Fil subspecies growing in Corsica (France), Tuscany and Sardinia (Italy). Flavour Fragr. J. 2003, 18, 487-491. [CrossRef]

225. Perrini, R.; Morone-Fortunato, I.; Lorusso, E.; Avato, P. Glands, essential oils and in vitro establishment of Helichrysum italicum (Roth) G. Don ssp. microphyllum (Willd.) Nyman. Ind. Crops Prod. 2009, 29, 395-403. [CrossRef]

226. Melito, S.; Sias, A.; Petretto, G.L.; Chessa, M.; Pintore, G.; Porceddu, A. Genetic and metabolite diversity of Sardinian populations of Helichrysum italicum. PLoS ONE 2013, 8. [CrossRef] [PubMed]

227. Giovanelli, S.; De Leo, M.; Cervelli, C.; Ruffoni, B.; Ciccarelli, D.; Pistelli, L. Essential Oil Composition and Volatile Profile of Seven Helichrysum Species Grown in Italy. Chem. Biodivers. 2018, 15. [CrossRef]

228. Bianco, A.; Guiso, M.; Mazzei, R.A.; Piccioni, F.; Nicoletti, M.; Serafini, M.; Ballero, M. 6'-Oacetylantirrhinoside, a new iridoid glucoside from Linaria flava subsp. sardoa. Fitoterapia 1996, 67, 364-366.

229. Fancello, F.; Zara, S.; Petretto, G.L.; Chessa, M.; Addis, R.; Rourke, J.P.; Pintore, G. Essential oils from three species of Mentha harvested in Sardinia: Chemical characterization and evaluation of their biological activity. Int. J. Food Prop. 2017, 20, 1751-1761. [CrossRef]

230. Marengo, A.; Maxia, A.; Sanna, C.; Mandrone, M.; Bertea, C.M.; Bicchi, C.; Sgorbini, B.; Cagliero, C.; Rubiolo, P. Intra-specific variation in the little-known Mediterranean plant Ptilostemon casabonae (L.) Greuter analysed through phytochemical and biomolecular markers. Phytochemistry 2019, 161, 21-27. [CrossRef]

231. Ascrizzi, R.; Cioni, P.L.; Amadei, L.; Maccioni, S.; Flamini, G. Geographical patterns of in vivo spontaneously emitted volatile organic compounds in Salvia species. Microchem. J. 2017, 133, 13-21. [CrossRef]

232. Rapposelli, E.; Melito, S.; Barmina, G.G.; Foddai, M.; Azara, E.; Scarpa, G.M. Relationship between soil and essential oil profiles in Salvia desoleana populations: Preliminary results. Nat. Prod. Commun. 2015, 10, 1615-1618. [CrossRef]

233. Poli, F.; Bonsignore, L.; Loy, G.; Sacchetti, G.; Ballero, M. Comparison between the essential oils of Santolina insularis (Genn. ex Fiori) Arrigoni and Santolina corsica Jord. et Fourr. from the island of Sardinia (Italy). J. Ethnopharmacol. 1997, 56, 201-208. [CrossRef]

234. Ferrari, B.; Tomi, F.; Richomme, P.; Casanova, J. Two new irregular acyclic sesquiterpenes aldehydes from Santolina corsica essential oil. Magn. Reson. Chem. 2005, 43, 73-74. [CrossRef]

235. Ferrari, B.; Tomi, F.; Richomme, P.; Casanova, J. Terpenes and acetylene derivatives from the roots of Santolina corsica (Asteraceae). Biochem. Syst. Ecol. 2005, 33, 445-449. [CrossRef]

236. Fattorusso, E.; Santelia, F.U.; Appendino, G.; Ballero, M.; Taglialatela-Scafati, O. Polyoxygenated Eudesmanes and trans-Chrysanthemanes from the Aerial Parts of Santolina insularis. J. Nat. Prod. 2004, 67, 37-41. [CrossRef] [PubMed]

237. Ramunno, A.; Serrilli, A.M.; Piccioni, F.; Serafini, M.; Ballero, M. Taxonomical markers in two endemic plants of Sardinia: Verbascum conocarpum and Scrophularia trifoliata. Nat. Prod. Res. 2006, 20, 511-516. [CrossRef] [PubMed]

238. Bellino, A.; Venturella, P.; Luisa Marino, M.; Servettaz, O.; Venturella, G. Coumarins from Seseli bocconi. Phytochemistry 1986, 25, 1195-1199. [CrossRef]

239. Serrilli, A.M.; Ramunno, A.; Piccioni, F.; Serafini, M.; Ballero, M. Flavonoids and iridoids from Stachys corsica. Nat. Prod. Res. 2005, 19, 561-565. [CrossRef] [PubMed] 
240. Tundis, R.; Peruzzi, L.; Menichini, F. Phytochemical and biological studies of Stachys species in relation to chemotaxonomy: A review. Phytochemistry 2014, 102, 7-39. [CrossRef] [PubMed]

241. Serrilli, A.M.; Ramunno, A.; Piccioni, F.; Serafini, M.; Ballero, M.; Bianco, A. Monoterpenoids from Stachys glutinosa L. Nat. Prod. Res. 2006, 20, 648-652. [CrossRef]

242. Mariotti, J.P.; Costa, J.; Bianchini, A.; Bernardini, A.F.; Casanova, J. Composition and Variability of the Essential Oil of Stachys glutinosa L. from Corsica (France). Flavour Fragr. J. 1997, 12, 205-209. [CrossRef]

243. Corticchiato, M.; Bernardini, A.; Costa, J.; Bayet, C.; Saunois, A.; Voirin, B. Free flavonoid aglycones from Thymus herba barona and its monoterpenoid chemotypes. Phytochemistry 1995, 40, 115-120. [CrossRef]

244. Dell'Agli, M.; Sanna, C.; Rubiolo, P.; Basilico, N.; Colombo, E.; Scaltrito, M.; Ndiath, O.; Maccarone, L.; Taramelli, D.; Bicchi, C.; et al. Anti-plasmodial and insecticidal activities of the essential oils of aromatic plants growing in the Mediterranean area. Malar. J. 2012, 11. [CrossRef]

245. Crippa, S.; Danieli, B.; Lesma, G.; Palmisano, G.; Ferrari, G.; Vecchietti, V. Indole alkaloids from Vinca sardoa, a new species of Vinca. Heterocycles 1990, 31, 1663-1667.

246. Nicoletti, M.; Serafini, M.; Federici, E.; Galeffi, C.; Poli, F. Indole alkaloids from aerial parts of Vinca sardoa. Phytochemistry 1998, 47, 149-151. [CrossRef]

247. Bianco, A.; Guiso, M.; Nicoletti, M.; Foddai, S.; Piccin, A.; Serafini, M.; Ballero, M.; Poli, F. A comparative chemotaxonomic study on Vinca sardoa Stearn and Vinca difformis Pourret. Nat. Prod. Res. 2005, 19, 615-617. [CrossRef] [PubMed]

248. Sacchetti, G.; Ballero, M.; Serafini, M.; Romagnoli, C.; Bruni, A.; Poli, F. Laticifer tissue distribution and alkaloid location in Vinca sardoa (Stearn) Pign. (Apocynaceae), an endemic plant of Sardinia (Italy). Phyt. Ann. Rei Bot. 1999, 39, 265-275.

249. Danieli, B.; Lesma, G.; Palmisano, G.; Ferrari, G.; Vecchietti, V.; Picci, V.; Atzei, A. Indole alkaloids from Vinca sardoa, a new species of Vinca. Planta Med. 1980, 39, 207.

250. Verpoorte, R. Exploration of nature's chemodiversity: The role of secondary metabolites as leads in drug development. Drug Discov. Today 1998, 3, 232-238. [CrossRef]

251. Schippmann, U.; Leaman, D.; Cunningham, A.B. A Comparison of Cultivation and Wild Collection of Medicinal and Aromatic Plants under Sustainability Aspects. Med. Aromat. Plants 2007, 75-95. [CrossRef]

252. Cogoni, D.; Sulis, E.; Bacchetta, G.; Fenu, G. The unpredictable fate of the single population of a threatened narrow endemic Mediterranean plant. Biodivers. Conserv. 2019, 28, 1799-1813. [CrossRef]

253. Fenu, G.; Cogoni, D.; Ulian, T.; Bacchetta, G. The impact of human trampling on a threatened coastal Mediterranean plant: The case of Anchusa littorea Moris (Boraginaceae). Flora Morphol. Distrib. Funct. Ecol. Plants 2013, 208, 104-110. [CrossRef]

254. Orsenigo, S.; Montagnani, C.; Fenu, G.; Gargano, D.; Peruzzi, L.; Abeli, T.; Alessandrini, A.; Bacchetta, G.; Bartolucci, F.; Bovio, M.; et al. Red Listing plants under full national responsibility: Extinction risk and threats in the vascular flora endemic to Italy. Biol. Conserv. 2018, 224, 213-222. [CrossRef]

255. Porceddu, M.; Sanna, M.; Serra, S.; Manconi, M.; Bacchetta, G. Seed germination requirements of Hypericum scruglii, an endangered medicinal plant species of Sardinia (Italy). Botany 2020, cjb-2020-0039. [CrossRef]

256. Fenu, G.; Bacchetta, G.; Charalambos, S.C.; Fournaraki, C.; Giusso del Galdo, G.P.; Gotsiou, P.; Kyratzis, A.; Piazza, C.; Vicens, M.; Pinna, M.S.; et al. An early evaluation of translocation actions for endangered plant species on Mediterranean islands. Plant Divers. 2019, 41, 94-104. [CrossRef] [PubMed]

257. Coelho, N.; Gonçalves, S.; Romano, A. Endemic plant species conservation: Biotechnological approaches. Plants 2020, 9, 345. [CrossRef] [PubMed]

(C) 2020 by the authors. Licensee MDPI, Basel, Switzerland. This article is an open access article distributed under the terms and conditions of the Creative Commons Attribution (CC BY) license (http://creativecommons.org/licenses/by/4.0/). 